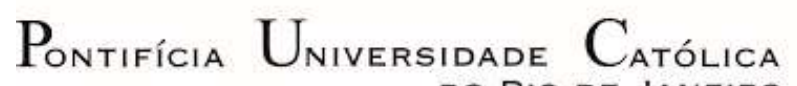
DO RIO DE JANEIRO

Silvia Leticia Queiroz da Silva

\title{
PRÉ-VESTIBULARES COMUNITÁRIOS E SUA IMPORTÂNCIA NA TRAJETÓRIA DAS MULHERES MORADORAS DE FAVELAS - 0 CASO DE COSTA BARROS
}

Dissertação apresentada como requisito parcial para obtenção do grau de Mestre pelo Programa de PósGraduação em Serviço Social do Departamento de Serviço Social da PUC-Rio.

Orientadora: Prof. a Andreia Clapp Salvador 
Pontifícia U Uiversidade Católica $_{\text {a }}$

DO RIO DE JANEIRO

Silvia Leticia Queiroz da Silva

\section{PRÉ-VESTIBULARES COMUNITÁRIOS E SUA IMPORTÂNCIA NA TRAJETÓRIA DAS MULHERES MORADORAS DE FAVELAS - 0 CASO DE COSTA BARROS}

Dissertação apresentada como requisito parcial para a obtenção do grau de Mestre pelo Programa de PósGraduação em Serviço Social da PUC-Rio. Aprovada pela Comissão Examinadora abaixo.

Prof. ${ }^{\text {a }}$ Andreia Clapp Salvador

Orientadora

Departamento de Serviço Social - PUC-Rio

Prof. Rafael Soares Gonçalves

Departamento de Serviço Social - PUC-Rio

Prof. Renato Pontes Costa

Departamento de Educação - PUC-Rio

Rio de Janeiro, 28 de abril de 2021 
Todos os direitos reservados. É proibida a reprodução total ou parcial do trabalho sem autorização da universidade, da autora e do orientador.

\section{Silvia Leticia Queiroz da Silva}

Graduada em Serviço Social na Pontifícia Universidade Católica do Rio de Janeiro (PUC-Rio), em 2010. Especializou-se em Gestão de Recursos Humanos, em 2014, pela Universidade Cândido Mendes e em Gestão de Políticas Sociais, em 2020, pela Universidade Castelo Branco. Membro do Grupo de Pesquisa de Ações Afirmativas e Reconhecimento (GPAAR).

Ficha Catalográfica

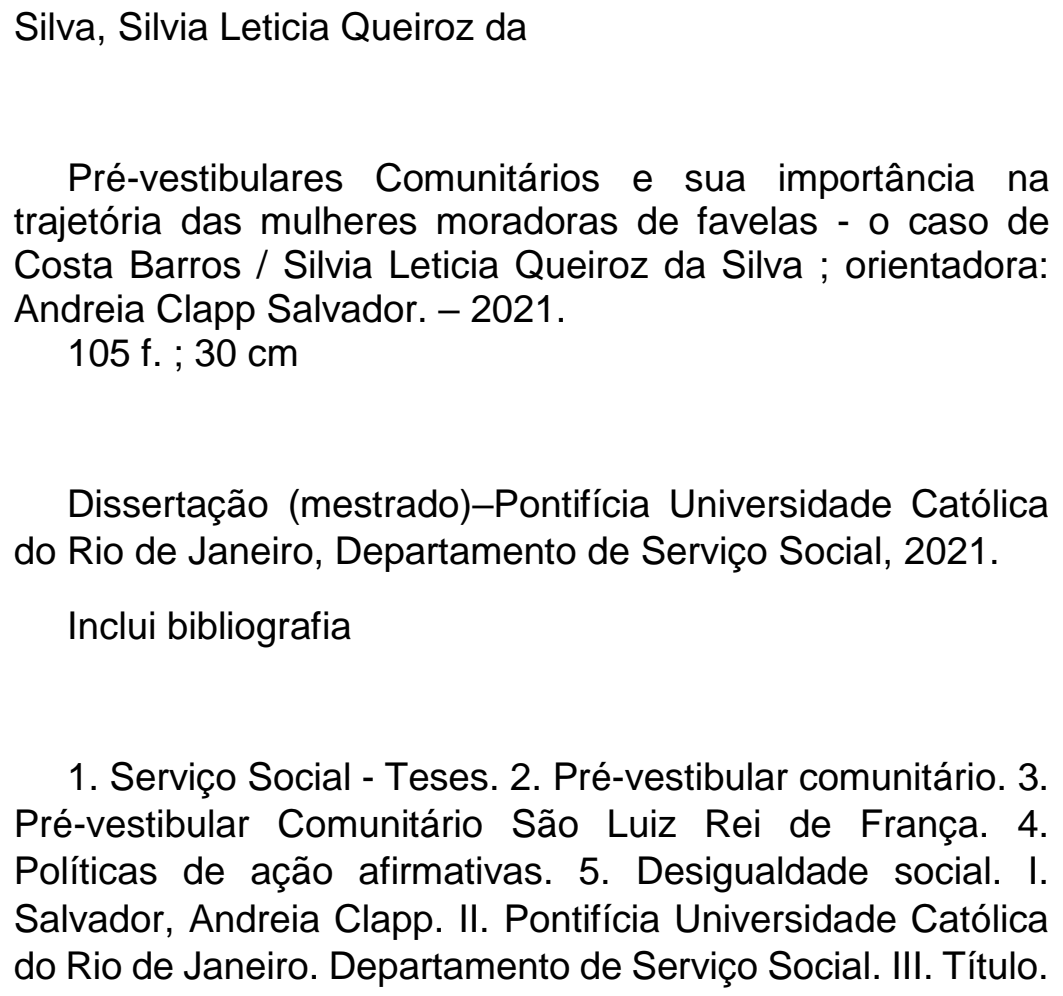

1. Serviço Social - Teses. 2. Pré-vestibular comunitário. 3. Pré-vestibular Comunitário São Luiz Rei de França. 4. Políticas de ação afirmativas. 5. Desigualdade social. I. Salvador, Andreia Clapp. II. Pontifícia Universidade Católica do Rio de Janeiro. Departamento de Serviço Social. III. Título. 
Ao Eduardo, meu amado marido, que infelizmente não está mais no plano terreno, mas que foi meu grande incentivador para que eu pudesse chegar até aqui. A ele toda a minha gratidão. 


\section{Agradecimentos}

Primeiramente, quero agradecer a Deus por ter sido refúgio e fortaleza em tempos tão difíceis. Ao meu marido Eduardo, por todo apoio e dedicação. À minha mãe, que mesmo com suas limitações, me incentivou e me apoiou a todo momento. Aos meus irmãos, Leonardo e Silvana, que me acolheram e me deram o suporte necessário em minha caminhada.

À minha orientadora, Andreia Clapp Salvador, que mesmo nos momentos difíceis me fortaleceu, confiou no meu potencial e tornou-se minha amiga, estreitando laços que criamos, ainda na graduação, minha eterna gratidão!

Ao professor Rafael Soares Gonçalves, pois tão generosamente participou da minha banca de qualificação do meu projeto e, mais uma vez, aceitou meu convite para participar da minha banca de defesa do mestrado, suas contribuições foram de extrema importância para que eu pudesse chegar até aqui.

À professora Valéria Pereira Bastos, que em minha passagem, tanto pela graduação quanto pelo mestrado, mesmo com a distância física do último ano, me amparou e me acolheu, nunca poderei expressar em palavras quão grata eu me sinto.

Aos Professores Kamila Teixeira e Renato Pontes Costa, esses respectivamente aceitaram participar da minha banca de qualificação e de mestrado, suas contribuições foram de extrema importância para o andamento e finalização desta pesquisa. 
A todas as ex-alunas do Pré-Vestibular Comunitário São Luiz Rei de França (PVCSLRF), que concederam as entrevistas, a base fundamental desta pesquisa.

Às minhas amigas de graduação Lorena, Izabel e Aline, fundamentais para que eu pudesse ingressar no mestrado e que nesses dois anos sempre vibraram com as minhas conquistas, amo vocês!

Aos meus amigos da turma 2019.1, pelo acolhimento, companheirismo e amizade. Arrasamos!

Agradeço a um grupo em especial, Suzana, Leandro, Patrick, Felipe e Luana, que foram conselheiros e dividiram cada passo dessa experiência comigo, levarei vocês para minha vida. Também à Alyne, que chegou até aqui e criamos um laço de amizade que quero levar para sempre, mesmo com todas as nossas lamentações.

Aos meus amigos da vida, nunca poderei retribuir tudo o que já fizeram por mim, como fui abençoada em tê-los em minha vida, quero expressar aqui todo meu amor à Aline, ao Amauri, à Tainan, Eveline e Suelen, pelos conselhos, amizade, carinho, companheirismo e total confiança que sempre depositaram em mim. A torcida de vocês foi impulso para que eu pudesse concluir essa etapa da minha vida.

Ao Departamento de Serviço Social, sobretudo, à Joana Félix, por estar sempre disponível em nos atender.

O presente trabalho foi realizado com apoio da Coordenação de Aperfeiçoamento de Pessoal de Pessoal de Nível Superior - Brasil (CAPES) - Código de Financiamento 001. 


\section{Resumo}

Silva, Silvia Leticia Queiroz da; Salvador, Andreia Clapp. Pré-Vestibulares Comunitários e sua Importância na Trajetória das Mulheres Moradoras de Favelas - O Caso de Costa Barros. Rio de Janeiro, 2021, 105p. Dissertação de Mestrado - Departamento de Serviço Social, Pontifícia Universidade Católica do Rio de Janeiro.

O objetivo deste trabalho é analisar a trajetória das ex-alunas do Pré-Vestibular Comunitário São Luiz Rei de França (PVCSLR) a partir do momento em que ocorreu a formação dessas em um curso de nível superior, e de que forma o Pré-vestibular Comunitário contribuiu para que ocorresse, não somente o ingresso no espaço universitário, mas também mudanças efetivas na vida dessas mulheres. Partiu-se do pressuposto, de que o (PVCSLRF) foi de extrema importância para que houvesse uma real transformação na vida das ex-alunas, levando em consideração que todas elas são oriundas das favelas localizadas no bairro de Costa Barros (Morro da Pedreira, Morro do Lagartixa, Morro do Chapadão, dentre outros), que é uma localidade com alto índice de violência, pobreza e desigualdade social. O PVCSLRF também tem como base a Igreja Católica, sendo seus fundadores e Coordenadores todos membros ativos da Paróquia São Luiz Rei de França, situada em Costa Barros, bairro do subúrbio do Rio de janeiro, durante seu período de exercício, que ocorreu entre os anos de 2005 a 2010. Para alcançar o objetivo proposto por esse estudo - e com base na pesquisa de campo - optou-se como metodologia a utilização da pesquisa qualitativa. Para coleta de dados, optou-se pela aplicação de entrevista junto as ex-alunas, isto é, sete (7) mulheres que participaram das aulas do PVCSLRF, durante os anos em que o mesmo esteve ativo. Com base no momento em que estamos vivendo, devido à pandemia do novo Coronavírus, optamos fazer contato com as ex-alunas por meio de telefone e internet e realizar todas as entrevistas por chamada de vídeo. A partir disso, foram localizadas dez (10) ex-alunas, tendo retorno de sete (7), assim, prosseguimos com as entrevistas, coleta e análise de dados. Concomitante a análise dos dados, foi realizada também a revisão bibliográfica, assim pudemos chegar nos objetivos traçados no início dessa pesquisa. Ao final do estudo, percebeu-se pela da fala das entrevistadas, que o PVCSLRF foi de extrema importância na trajetória dessas mulheres, não apenas para o ingresso nas universidades, mas, também, durante a experiência no espaço universitário e também após sua formação de nível superior, todas falaram de maneira muito positiva sobre suas experiências nas aulas, o 
quanto o curso foi importante para a disseminação de informações, visto que no início dos anos 2000, não havia acesso à informação e à internet como há nos dias atuais. Concluiu-se também que ter um equipamento que possibilitou a inserção no ensino superior de uma população que vivia no cerne das desigualdades sociais foi um ponto extremamente positivo para a população local, visto que, naquele período, não se tinha muito incentivo para o ingresso da classe trabalhadora no espaço universitário e este era, de certa maneira, restrito a pessoas oriundas de classes privilegiadas, tornando um lugar de difícil acesso para os demais.

\section{Palavras-Chave}

Pré-Vestibular Comunitário; Políticas de Ação Afirmativas; Desigualdade Social. 


\section{Abstract}

Silva, Silvia Leticia Queiroz da; Salvador, Andreia Clapp (Advisor). Community Pre-Vestibularies and their Importance in the Trajectory of Women Who Live in Slumble - The Case of Costa Barros. Rio de Janeiro, 2021, 105p. Dissertação de Mestrado - Departamento de Serviço Social, Pontifícia Universidade Católica do Rio de Janeiro.

The objective of this work is to analyze the trajectory of the ex-students of the São Luiz Rei de França Community Pre-University Entrance Examination (PVCSLR) from the moment that they formed in a higher education course, and in what way the Preuniversity entrance exam Communitarian contributed to the occurrence, not only of entering the university space, but also effective changes in the lives of these women. It was assumed that (PVCSLRF) was extremely important for there to be a real transformation in the lives of the former students, taking into account that they all come from the slums located in the neighborhood of Costa Barros (Morro da Pedreira, Morro do Lagartixa, Morro do Chapadão, among others), which is a location with a high rate of violence, poverty and social inequality. The PVCSLRF is also based on the Catholic Church, its founders and Coordinators being all active members of the Parish of São Luiz Rei de França, located in Costa Barros, a suburb of the suburb of Rio de Janeiro, during its period of exercise, which occurred between the years from 2005 to 2010. In order to achieve the objective proposed by this study - and based on the field research - the use of qualitative research was chosen as a methodology. For data collection, it was decided to apply an interview with the former students, that is, seven (7) women who participated in the PVCSLRF classes, during the years in which it was active. Based on the moment we are living in, due to the pandemic of the new Coronavirus, we chose to make contact with the alumni through telephone and internet and carry out all interviews by video call. From that, ten (10) former students were located, with a return of seven (7), so we proceeded with the interviews, data collection and analysis. Concomitant with the analysis of the data, a bibliographic review was also carried out, so that we could reach the objectives outlined at the beginning of this research. At the end of the study, it was clear from the interviewees' speech that the PVCSLRF was extremely important in the trajectory of these women, not only for entering universities, but also during their experience in the university space and also after their formation. university level, all spoke in a very positive way about their experiences in class, how important the course was for the 
dissemination of information, since in the early 2000s, there was no access to information and the internet as there is today. It was also concluded that having equipment that enabled the insertion in higher education of a population that lived at the heart of social inequalities was an extremely positive point for the local population, since, at that time, there was not much incentive for the entry of the population. working class in the university space and this was, in a way, restricted to people from privileged classes, making it a place of difficult access for others.

\section{Keywords}

Community Pre-University Entrance Exam; Affirmative Action Policies; Social inequality. 


\section{Sumário}

1. Introdução

2. Os Cursos Pré-Vestibulares Comunitários - O que são? 26

2.1 Os Cursos Pré-Vestibulares Comunitários - CPVCs 26

2.2 O Pré-Vestibular Comunitário São Luiz Rei de França - A 32

Sua Gênese

3. Desigualdade Social e Pobreza 38

3.1 Desigualdade Social e Pobreza e seus Rebatimentos na 39

Vida das Ex-Alunas do Pré-Vestibular Comunitário São Luiz Rei de França

4. Políticas de Ações Afirmativas 48

4.1 As Políticas de Ações Afirmativas: Alguns Apontamentos 50

4.2 As Políticas de Ações Afirmativas no Ensino Superior - O 58

Papel das Universidades

4.3 A inserção das Ex-alunas do Pré-Vestibular Comunitário

São Luiz Rei de França nas Universidades, por intermédio das

Políticas de Ações Afirmativas

5. A importância do Pré-Vestibular Comunitário São Luiz Rei de

França na trajetória de vida Pós-Universidade - A perspectiva das ex-alunas

5.1. O Perfil das Ex-Alunas do Pré-Vestibular Comunitário São

Luiz Rei de França

5.2. O Pré-Vestibular Comunitário São Luiz Rei de França - A

sua importância para as ex-alunas

5.3. A Política de Ação Afirmativa na Perspectiva das Ex-Alunas

5.4. Trajetória pessoal, profissional e acadêmica das Ex-Alunas do Pré-Vestibular Comunitário São Luiz Rei de França 
6. Considerações finais

7. Referências bibliográficas

8. Apêndices

103

8.1 Roteiro de Entrevista com as Ex-Alunas

103

8.2. Termo de Consentimento Livre e Esclarecido 


\title{
Lista de Siglas
}

\author{
$\mathrm{AE} \quad$ Assistência Estudantil \\ CPVCs Cursos Pré-Vestibulares Comunitários \\ EDUCAFRO Educação e Cidadania de Afrodescendentes \\ ENEM Exame Nacional do Ensino Médio \\ IDH Índice de Desenvolvimento Humano \\ PVCSLRF Pré-vestibular Comunitário São Luiz Rei de França \\ PVNC Pré-Vestibulares para Negros e Carentes \\ PVP Pré-Vestibulares Populares \\ ProUni Programa Universidade para Todos \\ REUNI Programa de Apoio a Planos de Reestruturação e Expansão das \\ Universidades Federais \\ PUC- Rio Pontifícia Universidade Católica do Rio de Janeiro \\ UERJ Universidade Estadual do Rio de Janeiro \\ UENF Universidade do Norte Fluminense
}




\section{Lista de gráficos}

Gráfico 1 - Idade das ex-alunas $\quad 69$

Gráfico 2 - Estado civil declarados pelas ex-alunas 70

$\begin{array}{ll}\text { Gráfico } 3 \text { - Raça autodeclarada } & 70\end{array}$

Gráfico 4 - Ano em que ingressaram na Universidade 71

Gráfico 5 - Curso que concluíram $\quad 72$

Gráfico 6 - Formas de ingresso na Universidade 73 


\section{Lista de Tabelas}

Tabela 1 - Dados das entrevistadas 


\section{1 \\ Introdução}

O presente trabalho tem por objetivo analisar a trajetória das ex-alunas do PréVestibular Comunitário São Luiz Rei de França, a partir do momento em que ocorreu a formação dessas em um curso de nível superior, e de que forma o Curso Pré-vestibular Comunitário contribuiu para que ocorresse não somente o ingresso no espaço universitário, mas também mudanças efetivas na vida dessas mulheres.

Costa Barros é um bairro formado por um conjunto de favelas (Morro da Pedreira, Quitanda, Lagartixa e Chapadão - que são as favelas maiores, mais antigas e conhecidas - e algumas mais recentes, que são a Terra Nostra, Obrigado Meu Deus e a Final Feliz - menores e menos conhecidas), que segundo o Instituto Brasileiro de Geografia e Estatística (IBGE) é um dos bairros com menor Índice de Desenvolvimento Humano (IDH) da cidade, ficando no último CENSO em penúltimo lugar (Lista de bairros, 2020).

As mulheres que pesquisamos são ex-alunas do Pré-vestibular Comunitário São Luiz Rei de França e moradoras do bairro acima citado, assim, tivemos como perspectiva avaliar 1) como se deu a trajetória dessas mulheres, durante a Universidade, mas principalmente, após sua conclusão; 2) e qual o papel do Prévestibular Comunitário, enquanto recurso para conquista da vaga no ensino superior, e como um espaço de formação existente no interior do bairro e que capacitava os jovens para tal ingresso; 3) e como a Política de Ação Afirmativa foi determinante para o ingresso desse grupo nas universidades.

Buscamos, nesta pesquisa, pensar: como se deu a inserção e permanência dessas ex-alunas no Ensino Superior, a partir de sua participação no Curso Prévestibular Comunitário (CPVC)? Qual o perfil dessas ex-alunas? Quais mudanças ocorreram na trajetória dessas ex-alunas a partir do ingresso na Universidade? E quais os impactos da formação universitária na vida das ex-alunas do Pré-Vestibular Comunitário São Luiz Rei de França (PVCSLRF)? 
O espaço da Universidade historicamente, por diferentes práticas, não incluía pessoas com capital cultural não valorizado socialmente, isto é, pessoas oriundas das classes populares, grupos em condição de desigualdade social, alunos que vieram de uma educação pública, que além de tudo, em alguns casos, possui uma qualidade discutível. As Universidades, de maneira geral, não prezavam por receber esses alunos, visto que existia um enorme preconceito por parte da comunidade universitária, que partiam do princípio de que esse grupo iria "desvalorizar" o ensino da Instituição, até mesmo baixando as notas de produtividade dos cursos. Por excelência, a Universidade é um lócus privilegiado para quem não é da favela, portanto, para Nascimento (2010),

(...) o ensino superior brasileiro é, notadamente, lugar de produção e reprodução de uma elite e de uma tecnocracia oriundas dos setores sociais economicamente privilegiados (empresariado, profissionais liberais, alto funcionalismo público), em sua maioria composta pelo grupo da população que o Instituto Brasileiro de Geografia e Estatística (IBGE) classifica como brancos (Nascimento, 2010, p. 49$50)$.

Logo, ter pessoas advindas de camadas mais populares dentro dos espaços da Universidade, assim como o ingresso das mulheres moradoras de favela no ensino superior, é de suma importância para que elas acessem a diferentes graus de conhecimento e tenham em suas vidas mudanças culturais, sociais e econômicas.

Nesta pesquisa, trabalhamos com as seguintes categorias de análise: Prévestibular Comunitário, Políticas de Ação Afirmativa e Desigualdade Social.

Os Cursos Pré-vestibulares Comunitários (CPVC's) são criados numa perspectiva de minimizar as desigualdades sociais existentes, como as de renda, raça, educacionais, etc. que historicamente excluíram os grupos mais fragilizados das Universidades, além de contribuir para que essa população, que não teria condições de pagar por um curso preparatório privado, tenham chances no momento do ingresso ao ensino superior.

De acordo com Ângela Paiva (2015),

Se antes essa preparação era restrita às classes média e alta pelo seu alto custo, os pré-vestibulares comunitários começam a qualificar novos candidatos para o vestibular em um processo lento, porém sustentado. Hoje são vários, organizados em associações, escolas, igrejas, universidades. E com as políticas posteriores pensadas pelo MEC, este acesso passa a ser uma realidade efetiva, uma vez que houve forte ação governamental para a expansão do ensino superior. Como resultado concreto da confluência trazida aqui, as políticas governamentais 
encontram uma parcela expressiva de jovens moradores da periferia ou de favelas que passaram a estar em condições mínimas de igualdade de chegar ao vestibular (Paiva, 2015, p. 143).

O ponto principal dos CPVC's é possibilitar que estudantes em condições de desigualdade social ingressem no ensino superior, fazendo com que haja, mesmo que minimamente, a democratização do acesso à educação para grupos historicamente marginalizados, além disso, sua perspectiva vai para além do ensino e aprendizagem, tem um cunho informativo, visto que muitos desses alunos não têm acesso à informação e até mesmo à internet, e uma proposta cidadã, que faz com que o público menos favorecido tenha possibilidade de ingresso no ensino superior e tenha alterações efetivas na trajetória de vida dessas pessoas.

Com base na ideia de ingresso do jovem oriundo de classes populares no ensino superior, esta pesquisa contou com a perspectiva de que o Pré-Vestibular Comunitário São Luiz Rei de França, no qual, ao longo de sua existência, não houve um estudo que entendesse a trajetória percorrida por suas ex-alunas, concluintes do ensino superior, tenha sido um instrumento que nos ajudou a abordar quais foram os impactos reais da conclusão do curso universitário na vida dessas mulheres, não esquecendo de colocá-las como protagonistas de suas próprias histórias.

Os CPVCs surgiram com a perspectiva de inclusão da população que vive no cerne da desigualdade social no ensino superior e para que grupos socialmente excluídos e que, geralmente, são oriundos de escolas públicas acessem ao espaço universitário. Esses grupos, de modo geral, emergem de um ensino precário e de uma série de defasagens, não conseguindo ou se tornando mais difícil o seu ingresso na universidade, seja por meio do vestibular ou via Exame Nacional do Ensino Médio (ENEM), ficando quase que impossível concorrer com alunos que vieram da rede privada.

Nesse contexto, algumas análises concluem que as camadas da população brasileira de maior poder aquisitivo, que são as que podem pagar por cursos e escolas que capacitam para os exames de seleção das universidades públicas, são subsidiadas pelo Estado durante o ensino superior, ao passo que as camadas mais pobres ficam prejudicadas porque o mesmo subsídio estatal é deficitário para o ensino básico (Nascimento, 2010, p. 50).

Ainda sobre isso, Nascimento (2010) nos traz que,

Analisando desse ponto de vista, pode-se concluir que o ensino básico público não capacita seus estudantes, em sua maioria pobres, para o acesso ao ensino superior 
oferecido pelas universidades públicas, que em geral é de melhor qualidade e proporcionam melhores condições profissionais aos seus estudantes, por gozarem estas instituições de maior reconhecimento social. Ou seja, a culpa do baixo acesso dos pobres ao ensino superior é, em parte, atribuída à baixa qualidade do ensino oferecido pelas escolas públicas de ensino básico que são de competência de estados e municípios (Nascimento, 2010, p. 50,51).

A motivação para realizar a investigação a respeito da história destas mulheres, se deu a partir da minha experiência enquanto ex-aluna do curso, mas também enquanto moradora da localidade, essa experiência possibilitou, além da aproximação com o campo, um estímulo para a realização desta pesquisa.

No capítulo 2, traremos algumas questões relacionadas aos CPVC's, seu conceito e formação, em especial, o Pré-vestibular Comunitário São Luiz Rei de França, sua gênese, sua importância para as alunas durante seu período de existência e trajetória.

Já no capítulo 3, traremos à tona a discussão a respeito das desigualdades sociais em nossa sociedade, apesar da existência de políticas públicas voltadas para a população em situação de vulnerabilidade, ainda existe uma série de desigualdades que contribuem para que uma boa parcela da população fique na marginalidade do sistema. Essas desigualdades são também de gênero, raça, classe, incluindo nessa discussão a questão da desigualdade de renda e educacional, além de abordarmos algumas questões relacionadas à pobreza e como essa interfere diretamente na vida da população economicamente desfavorecida.

No capítulo 4, dissertamos sobre as Políticas de Ações Afirmativas, seu conceito, sua trajetória e sua importância não somente para o público que estamos pesquisando, mas em nosso país de maneira geral.

No capítulo 5, apresentaremos os resultados da pesquisa: o perfil das exalunas do PVCSLRF; O Pré-Vestibular Comunitário São Luiz Rei de França - a sua importância para as ex-alunas; as Políticas de Ações Afirmativas na Perspectiva das Ex-Alunas; a Trajetória pessoal, profissional e acadêmica das ExAlunas do Pré-Vestibular Comunitário São Luiz Rei de França.

Com a pesquisa, pretendemos responder à questão central deste estudo, que foi: de fato, houve mudança na trajetória de vida das mulheres moradoras de Costa Barros e oriundas do Pré-Vestibular Comunitário São Luiz Rei de França, a partir da conclusão de seu curso de nível superior? Ao que parece, muitas mulheres da classe popular e moradoras de favela encontram dificuldades para ingressar em uma Universidade, as dificuldades são desde o ingresso, 
permanência até a conclusão de seu curso, o que nos faz tentar entender a trajetória desse grupo.

A importância desta dissertação está relacionada à análise que será feita sobre a trajetória percorrida pelas mulheres, ex-alunas do Pré-vestibular Comunitário São Luiz Rei de França, sobretudo, após o ingresso e conclusão de seu curso de nível superior, todas moradoras de Costa Barros.

A temática foi pensada principalmente a partir de uma experiência pessoal, não somente enquanto ex-aluna do PVC, mas também como mulher e moradora da localidade. Fazendo um resgate anterior à elaboração do objeto que foi pesquisado neste trabalho, afirmo ter sido aluna de graduação do curso de Serviço Social pela Pontifícia Universidade Católica do Rio de Janeiro (PUC-Rio), sendo bolsista integral, bolsa essa, fruto de ações afirmativas ofertadas pela Universidade.

A partir de tal experiência, tornou-se inevitável não perceber que existe nas favelas um público que somente aguarda uma oportunidade de mudar sua história de vida e alterar suas perspectivas em relação ao que já havia sido traçado.

O recorte de gênero proposto neste trabalho se deu pelo fato de que há uma gama de mulheres que vivem nas favelas e possuem, em suas trajetórias, questões que precisam ser publicizadas e, mais que isso, problematizadas. Essas, que fazem parte de um pequeno grupo, que precisa ter suas histórias contadas, pois ainda temos, atualmente, um enorme preconceito em relação às pessoas que vêm das favelas e que carregam diversos estigmas.

As mulheres, que apesar de hoje serem maioria nas Universidades, tiveram que percorrer um caminho mais longo para chegarem a tal conquista, pois até poucas décadas atrás, elas saiam do crivo de seus pais para se tornarem posse de seus maridos, sendo-lhes negados não só o direito ao mercado de trabalho, mas também de ingresso nas universidades.

Tivemos nas últimas décadas uma entrada considerável da população em situação de desigualdade social nas Universidades, sejam elas públicas ou privadas, devido ao grande investimento que houve nas políticas de educação nesse período e principalmente de incentivo ao acesso no ensino superior. Mas esse ingresso se deu pelas lutas bem anteriores, datadas já na década de 1990, e a partir de movimentos sociais que reivindicavam a inserção do aluno negro e pobre nesses espaços, essas reivindicações culminaram nas políticas de ações afirmativas de cunho social e racial, que apresentaremos posteriormente.

Outro dispositivo que contribuiu para que as classes populares ingressassem no espaço da Universidade, tratamos aqui especificamente dos 
moradores de Costa Barros, foram os Cursos Pré-vestibulares Comunitários, nesse caso o Pré-vestibular Comunitário São Luiz Rei de França, teve grande importância para que os moradores das favelas acima citadas almejassem uma vaga no ensino superior e como o seu papel de ser um instrumento de acesso e disseminar informações contribuiu para este ingresso.

Conforme afirmado acima, o PVCSLRF ficava alocado em Costa Barros, que hoje é formado por um conjunto de favelas que tem um índice de violência extremamente alto, influência do tráfico e operações policiais recorrentes. É cotidiano que as escolas do entorno fiquem fechadas em dias de operação, o que nos faz pensar, que os estudantes desta localidade desde a educação básica, têm um ensino defasado e precário, devido à violência e o pouco incentivo do Estado, não somente na área da educação, mas nas políticas sociais como um todo.

Pensando enquanto moradora e ex-aluna do PVCSLRF, podemos afirmar que a importância dessa pesquisa foi a de trazer luz a essas mulheres que vivem marginalizadas e reféns de uma sociedade machista, violenta e que rotineiramente invisibiliza a mulher pobre/negra/favelada em suas lutas cotidianas.

Falar da trajetória, não só de vida, mas acadêmica dessas mulheres, é falar também, sobre os avanços, mobilidade e a ascensão social delas (caso tenha ocorrido e de que forma ocorreu), que são moradoras de favela e que em sua grande maioria são negras e participam ativamente da vida econômica de seu grupo familiar.

Para melhor justificar esta pesquisa, tivemos não só a relevância teórica, como também uma relevância pessoal e social. Seguem abaixo tais informações:

- No que diz respeito ao campo teórico, ao fazer um levantamento bibliográfico e dissertar sobre tal temática, contribuímos, não somente com o aumento do acervo, mas também com uma nova fonte de pesquisa relativa ao tema;

- A importância desta pesquisa está relacionada à análise que foi feita sobre a trajetória, após a conclusão do curso de nível superior, das ex-alunas do Pré-Vestibular Comunitário São Luiz Rei de França, visto que não temos nenhum estudo relativo a esse grupo;

- Falar sobre as mulheres oriundas de Costa Barros, bairro extremamente pobre e formado por favelas, além de levantar dados e entender o contexto 
em que elas estão inseridas, trouxe melhor entendimento sobre a realidade social desse grupo;

- Levantar dados que indiquem como o Pré-vestibular Comunitário São Luiz Rei de França, que tinha o seu funcionamento dentro de uma favela do bairro, cumpriu (ou não) seu papel enquanto instrumento de democratização de acesso da população pobre no ensino superior;

- Ser ex-aluna do Pré-vestibular São Luiz Rei de França, mulher, aluna fruto de Políticas de Ações Afirmativas e também ser moradora da localidade, fundamentam a questão pessoal.

Por fim, seguem-se as Considerações Finais, no Capítulo 6, onde faremos um apanhado de toda nossa pesquisa, levando em consideração informações relevantes que serviram de base para o início desta dissertação, até mesmo interesse pelo tema e quais conclusões chegamos em relação ao objeto de estudo abordado.

\section{Nota Metodológica}

Tomando como objeto de estudo a trajetória pós-universidade das exalunas do Pré-Vestibular Comunitário São Luiz Rei de França, escolheu-se um caminho metodológico que melhor nos ajudou a chegar aos resultados desta pesquisa.

Entendemos por metodologia o caminho do pensamento e a prática exercida na abordagem da realidade. Ou seja, a metodologia inclui simultaneamente a teoria da abordagem (o método), os instrumentos de operacionalização do conhecimento (as técnicas) e a criatividade do pesquisador (sua experiência, sua capacidade pessoal e sua sensibilidade) a metodologia ocupa um lugar central no interior das teorias e está referida a elas (Minayo, 2009, p. 14).

Para responder às questões levantadas e por melhor se aproximar de nosso propósito, adotaremos neste trabalho, o método de pesquisa qualitativa, que, de acordo com Minayo (2009), é conceituada da maneira abaixo:

A pesquisa qualitativa responde a questões muito particulares. Ela se ocupa, nas Ciências Sociais, com um nível de realidade que não pode ou não deve ser quantificado. Ou seja, ela trabalha com o universo dos significados, dos motivos, das aspirações, das crenças, dos valores e das atitudes. Esse conjunto de fenômenos humanos é entendido aqui como parte da realidade social, pois o ser 
humano se distingue não só por agir, mas por pensar sobre o que faz e por interpretar suas ações dentro e a partir da realidade vivida e partilhada com seus semelhantes. $O$ universo da produção humana que pode ser resumido no mundo das relações, das representações e da intencionalidade e é objeto da pesquisa qualitativa dificilmente pode ser traduzido em números e indicadores quantitativos. Por isso não existe um continuum entre abordagens quantitativas e qualitativas, como muita gente propõe, colocando uma hierarquia em que as pesquisas quantitativas ocupariam um primeiro lugar, sendo "objetivas e cientificas". E as qualitativas ficariam no final da escala, ocupando um lugar auxiliar e exploratório, sendo "subjetivas e impressionistas" (Minayo, 2009, p. 21).

Para chegar aos resultados desta pesquisa, realizamos entrevistas com as ex-alunas do PVCSLRF. As entrevistas que utilizamos em nosso processo de pesquisa, foram as semiestruturadas, que, segundo Minayo (2009, p. 64), “(...) combina perguntas fechadas e abertas, em que o entrevistado tem a possibilidade de discorrer sobre o tema em questão sem se prender à indagação formulada".

\begin{abstract}
Entrevista, tomada no sentido amplo de comunicação verbal, e no sentido restrito de coleta de informações sobre determinado tema científico, é a estratégia mais usada no processo de trabalho de campo. Entrevista é acima de tudo uma conversa a dois, ou entre vários interlocutores, realizada por iniciativa do entrevistador. Ela tem o objetivo de construir informações pertinentes para um objeto de pesquisa, e abordagem pelo entrevistador, de temas igualmente pertinentes com vistas a este objeto (Minayo, 2009, p. 64).
\end{abstract}

Realizamos as entrevistas com as ex-alunas do Pré-vestibular comunitário São Luiz Rei de França, nos meses de outubro e novembro de 2020, assim, pudemos entender a trajetória desse grupo após o término do curso de nível superior, para que, por fim, pudéssemos realizar a análise das informações fornecidas por elas. Fizemos a análise a partir da própria fala dessas mulheres, como foi o ingresso e permanência no ensino superior, quais dificuldades encontraram no percurso, como o CPVC auxiliou nesse ingresso e suas trajetórias após o fim do seu curso universitário. Lembrando que, foram utilizadas apenas as iniciais dos nomes das entrevistadas, para que pudesse se manter o sigilo em relação à identidade das ex-alunas.

Em relação às entrevistas realizadas com as ex-alunas, localizou-se dez (10) mulheres que cursaram o CPVC em seu período de exercício entre os anos de 2005 a 2010, tudo foi feito pelo telefone e internet, e assim, devido ao período 
de pandemia ${ }^{1}$ do novo Coronavírus ${ }^{2}$, todas as entrevistas foram realizadas de maneira virtual, pela plataforma Google Meet. Afirmamos então, que a partir dessas dez (10) mulheres, apenas sete (7) deram retorno, sendo assim, fizemos as entrevistas com esse grupo. O roteiro, em anexo possui 20 questões, que nos ajudaram a chegar aos objetivos estipulados nesta pesquisa, além de responderem às nossas hipóteses, que seriam: Após a conclusão do curso de nível superior, houve mudanças econômicas, culturais e sociais na vida das mulheres moradoras da localidade; As mulheres oriundas de Costa Barros, utilizaram o Pré-vestibular Comunitário São Luiz Rei de França, enquanto instrumento para acesso universitário e mobilidade social; Essas mulheres têm um grau de escolaridade maior em comparação às suas mães; O Pré-vestibular Comunitário São Luiz Rei de França contribuiu para que as mulheres moradoras de favela ingressassem em um curso de nível superior.

Realizamos também, entrevista com dois (2) dos cinco (5) excoordenadores do CPVC, com esses, conseguimos contato pelas redes sociais e telefone, para que esses pudessem contar um pouco da gênese e trajetória do PVCSLRF. Para eles, foi feita uma única pergunta e, assim, puderam nos auxiliar remontando a história do CPVC, visto que não há mais arquivos referentes ao curso, já que a paróquia passou por uma demolição e todos os documentos do período de existência do PVCSLRF foram perdidos na obra. A pergunta feita aos entrevistados foi a seguinte: Como foi a história do Pré-vestibular comunitário São Luiz Rei de França, sua gênese e trajetória? E a partir da fala dos dois entrevistados, conseguimos entender um pouco mais sobre a formação do curso.

Como afirmado anteriormente, as entrevistas foram realizadas de modo virtual, o que não trouxe dificuldade quanto à localização e ao agendamento das entrevistas, lembrando ainda que a maioria dessas mulheres ainda residem em

\footnotetext{
1 De acordo com Matta et al (2021) "Pandemia é um termo que designa uma tendência epidemiológica. Indica que muitos surtos estão acontecendo ao mesmo tempo e espalhados por toda parte. Mas tais surtos não são iguais. Cada um deles pode ter intensidades, qualidades e formas de agravo muito distintas e estabelece relações com as condições socioeconômicas, culturais, ambientais, coletivas ou mesmo individuais. Uma pandemia pode até mesmo se tornar evento em escala global. É o caso da Covid-19. Levou menos de três meses para que, no início de 2020, mais de 210 países e territórios confirmassem contaminações com o novo coronavírus, casos da doença e mortes. A escala global, no entanto, não significa que se trate de um fenômeno universal e homogêneo. É possível estabelecer padrões, identificar seu patógeno, compreender a sua mecânica biológica e sua transmissibilidade. Mas um vírus sozinho não faz pandemia, tampouco explica o processo saúde e doença presente em diferentes contextos" (p. 15).

${ }^{2}$ No final de 2019 na cidade de Wuhan, na China apareceu um vírus até então desconhecido e esse vírus causou uma pandemia mundial, que exigiu isolamento social e medidas sanitários em todo 0 mundo. Até da data de finalização dessa dissertação só o Brasil contabilizava o número de 411.588 de mortos e o número 14.856.888 de infectados pela doença Covid-19, de acordo com os dados do Ministério da Saúde.
} 
Costa Barros e mesmo àquelas que já não moram no bairro, teve a facilidade de encontrá-las pela internet, das redes sociais e por indicação dos excoordenadores do curso.

Por meio da nossa pesquisa, compreendemos o contexto em que essas mulheres estão inseridas, não somente para dar sustentação ao nosso trabalho, mas também clareza sobre a importância de colocá-las enquanto protagonistas de suas histórias, levando em consideração todo o processo de resistência estabelecido por elas para sobreviverem.

Enfim, para análise dos dados e elaboração da dissertação em si, contouse com orientação constante, esse suporte foi de extrema importância para entender, analisar e, por fim, responder às questões levantadas no início dessa pesquisa. 


\section{2}

\section{Os Pré-Vestibulares Comunitários - O que são?}

\section{1}

\section{Os Cursos Pré-Vestibulares Comunitários - CPVCs}

Falar sobre os cursos Pré-vestibulares comunitários dentro das favelas como instrumento de democratização de ensino superior que possibilita o ingresso da população em situação de desigualdade social nas Universidades, é de extrema importância para discutirmos os processos de mudança social por meio da educação desse grupo ainda tão marginalizado.

Os Pré-vestibulares Comunitários têm como objetivo possibilitar o acesso de grupos que vivem em situação de desigualdade social ao ensino superior, com a sua consolidação na década de 1990, surgiram vários cursos com essa perspectiva. Esses cursos têm sua base comunitária, como afirma Assis (2016, p.16), "O movimento dos Cursos Pré-Vestibulares Comunitários - CPVCS é um movimento de educação popular, com base comunitária e essa particularidade é uma característica que define a maneira como esse movimento se organiza".

De acordo com Zago (2008, p.152), a partir de estudos realizados, é possível identificar algumas características "que definem as propostas políticas e as condições de existência desses cursos, entre elas".

- atendimento aos setores, grupos ou frações de excluídos socialmente do acesso ao ensino superior e egressos de escolas públicas;

- são cursos gratuitos na sua maioria ou que cobram uma taxa que varia entre $5 \%$ a $10 \%$ do salário mínimo para despesas básicas relacionadas à manutenção das suas estruturas, transporte para professores e outros colaboradores;

- $\quad$ as propostas pedagógicas não têm como único objetivo a preparação para o vestibular. Na maioria dos PVP há um eixo curricular denominado "cultura e cidadania", nominação da disciplina obrigatória que privilegia um trabalho educativo voltado para o exercício da cidadania e este compreende a formação de uma consciência crítica frente aos problemas políticos, sociais e de discriminação racial no país;

- seu corpo docente e administrativo está apoiado em um trabalho de caráter voluntário;

- poucos são os cursos que possuem sede própria, eles funcionam em locais bastante diversificados: escolas, universidades, instituições religiosas, associações comunitárias, entre outros; 
- o número de vagas oferecido é variável segundo cada experiência (Zago, 2008, p. 152 [grifos meus]).

Os Pré-vestibulares comunitários têm um perfil diferente dos Prévestibulares privados, pois seu objetivo não é o lucro, mas sim contribuir na formação de seus alunos via ingresso na universidade e, após esse ingresso, esses alunos possuem a possibilidade de se promoverem socialmente. Entendemos por promoção social, nesse caso, as melhorias sociais na vida do aluno e da comunidade onde mora e também elevação da qualidade de vida deles, por meio de ações que possibilitem que esse aluno consiga mudanças significativas em sua vida pessoal e profissional.

Os CPVC's vão além da inclusão universitária, contribuem também para a promoção social de seus alunos, além do fortalecimento de acesso, a democratização desse acesso para as classes trabalhadoras, etc. $O$ trabalho dos Pré-vestibulares Comunitários, também se dá na perspectiva do estudante cidadão, tendo em seu conteúdo disciplinas que contribuem neste sentido, tudo isso pautado em uma análise crítica e social. Para Nascimento (2010),

(...) podemos considerar o Movimento dos Cursos Pré-Vestibulares Populares como ator social inovador e produtivo, cuja produção organiza, por meio de uma resistência criativa, uma luta política por inclusão não subornada e, como tal, pela universalização dos direitos e democratização das instituições de ensino (Nascimento, 2010, p. 47).

Ao longo das últimas décadas, iniciou-se um movimento em que se levantou uma antiga demanda, porém, naquele momento, tornou-se urgente: a inclusão da classe trabalhadora e de grupos socialmente discriminados nas Universidades. Esse movimento se fortaleceu, principalmente após a consolidação dos CPVC's na década de 1990, onde o mesmo contribuiu para o acesso e para a trajetória das classes populares no ensino superior.

Os cursos pré-vestibulares populares (PVP) ou também chamados comunitários surgem nesse contexto contraditório do sistema educacional, com profundas desigualdades no que diz respeito ao acesso ao ensino superior. Presenciamos desde os anos 90 várias iniciativas organizadas para protestar contra essa realidade e ao mesmo tempo produzir ações de combate às desigualdades na educação (Zago, 2008, p. 150).

Como sabemos, há um abismo que separa a população que vive no cerne da desigualdade social do ensino superior, existe uma série de questões que levam a esse abismo, além da problemática da qualidade do ensino público, o aluno pobre, que na maioria das vezes é aluno trabalhador e contribui com sua 
renda para manutenção de sua família, precisa lidar com outras questões como os horários das aulas e seu horário de trabalho, que normalmente não são flexíveis; o deslocamento de sua casa, caso seja em bairros periféricos, até a Universidade; o valor da passagem do transporte público; alimentação e outros gastos que surgem ao longo do curso.

Esse grupo já está previamente excluído do espaço universitário, por esse motivo a importância dos cursos pré-vestibulares comunitários, para que possam, por meio de seu trabalho, contribuir com essa reflexão e levar para a comunidade acadêmica as demandas trazidas por esses alunos, que fazem parte de grupos historicamente excluídos. Para Zago (2008),

Fazem parte de grupos sociais tradicionalmente excluídos do ensino superior (negros, moradores de bairros populares, egressos de escolas públicas), cuja problemática originou movimentos que reivindicam seu acesso, bem como o fortalecimento da universidade pública (Zago, 2008, p. 151,152).

Os Cursos Pré-vestibulares Comunitários surgiram a partir de uma evidente desigualdade de acesso ao ensino superior e ausência de políticas que possibilitassem a permanência dos alunos pobres nas Universidades, assim, trouxe à tona diversas discussões pertinentes, não só relacionadas ao acesso e permanência, mas também como um movimento que agrega participação popular (como alunos, professores, a própria equipe do CPVC e mobilização comunitária).

Para Nascimento (2010, p. 48), as "práticas e dinâmicas políticas desenvolvem-se no sentido da abertura do acesso ao ensino superior para estudantes pobres e negros, mobilizando milhares de pessoas em todo o país" ( $p$. 48). Ainda sobre a questão da mobilização, Nascimento (2010), nos traz que "é muito mais que uma mobilização caridosa, de pessoas que se reúnem para ajudar os que precisam".

Embora sua base seja comunitária e tenha um esforço dos seus participantes para manter os cursos ativos, os CPVC's trazem questões bem maiores, como por exemplo, o acesso à educação, que deveria ser um direito de todos, além de ser gratuita e de qualidade. Ainda de acordo com Nascimento (2010, p.48), "a educação brasileira, em geral, necessita melhorar quantitativamente e qualitativamente, para que seja um dos principais vetores de desenvolvimento democrático das relações sociais, e da produção cultural, política, científica, tecnológica e, pois, de melhores condições de vida".

As organizações dos Pré-vestibulares Comunitários, em suas primeiras experiências no Rio de Janeiro, tinham um recorte racial e social e eram chamados 
de Pré-Vestibulares para Negros e Carentes (PVNC), iniciaram com uma proposta que iria além da questão ensino/aprendizagem, pois, 1) são frutos de uma ação questionadora, de movimentos que lutam por garantia de direitos; 2) tem como um de seus princípios, tornar aquele aluno, que vem de uma classe econômica desfavorecida, um cidadão critico, capaz de analisar, questionar e reivindicar por direitos outrora negados; 3) "não se limitando apenas à produção de trajetórias de sucesso de alguns jovens (ou grupos), para que esses consigam entrar na "sociedade do conhecimento" e do consumo" (Nascimento, 2010, p. 60). Sobre o PVNC, este não se limitava a questão do ensino aprendizagem, como nos traz Assis (2016),

(...) sua atuação também se dá no campo político, isto é, nos espaços públicos de participação social e militância política. Contudo, essa característica faz do PVNC um movimento social de educação popular, que já no início de suas atividades expandiu rapidamente o número de seus núcleos e posteriormente serviu de referência para formação de diversos cursos com proposta semelhante à do PVNC ou não (Assis, 2016, p. 22).

A partir da concepção de democratizar o acesso à universidade aos alunos pobres, os PVNC's, envolveram-se numa série de demandas pertinentes a essa temática, como:

(...) reivindicações de isenção de taxa de inscrição de vestibular para os estudantes, negociações de bolsas de estudos, proposições de medidas e de apoio aos estudantes pobres e negros, participações em comissões de formulação e avaliação de políticas públicas, participações em pesquisas acadêmicas, manifestações e posicionamentos públicos em favor das políticas de ação afirmativa e da abertura das instituições ao seu trabalho e às suas propostas (escolas públicas e instituições e ensino superior, fundamentalmente), passaram a influenciar professores, gestores e legisladores a ponto de se servirem de base para questionamentos sobre desigualdades e relações produtoras de desigualdades, causando constrangimentos aos grupos que, historicamente, se beneficiam do fechamento, aos mais pobres e aos grupos sociais naturalizados pelo racismo como inferiores, do acesso aos direitos (Nascimento, 2010, p. 60,61).

Para além de todas as questões que foram levantadas a respeito dos PVNC's, podemos dizer que eles "exercem uma função política ao denunciar a discriminação racial e desigualdades escolares e sociais" (Zago, 2008, p. 159).

Os PVNC's, ao longo do tempo, contribuíram também para pôr em pauta algumas discussões importantes e auxiliar na formulação de políticas públicas, como por exemplo, as políticas de ações afirmativas. Para Nascimento (2010),

O movimento dos cursos pré-vestibulares, além de se constituir e trabalhar para romper as barreiras que dificultam o acesso das camadas populares ao ensino 
superior público, vem contribuindo para colocar em ação e como pauta na agenda política o conceito de ação afirmativa - como denominação geral dada ás políticas públicas e privadas de combate à discriminação e promoção da igualdade de oportunidades e tratamento - e, dentro deste marco, as propostas de políticas de cotas raciais e sociais como reivindicação geral de combate ao racismo e de redução das desigualdades observadas na composição do ensino superior (Nascimento, 2010, p. 59).

Sobre os Pré-Vestibulares Comunitários, (Zago, 2008, 159) nos afirma que representam "a oportunidade de retomada dos estudos ao mesmo tempo um espaço de sociabilidade e formação de subjetividades", esse espaço, também é de valorização do aluno, exploração de suas potencialidades, além de contribuir para troca de experiências entre alunos e professores.

Quando falamos de uma população que vem majoritariamente do ensino público e que não teria condições de concorrer de forma justa a uma vaga em uma Universidade, devido à precariedade do ensino da rede pública, entendemos que este grupo previamente já estará fora dessa disputa, mesmo porque as Universidades, até pela forma de ingresso, não dá oportunidade a pessoas vindas de grupos menos favorecidos.

\begin{abstract}
No que diz respeito ao ensino superior essa questão parece ser ainda mais complexa. O sistema de ensino superior no Brasil, composto por universidades, centros universitários e faculdades públicas e privadas, é historicamente herdeiro de um pacto social que entendemos como elitista (um pacto racista e conservador estabelecido pelos setores historicamente hegemônicos na política, na economia e na produção intelectual, que definiu hierarquias e lugares sociais). O formato de ensino superior fruto desse pacto é voltado para a classe proprietária e para os grupos que gozam de privilégios dentro do referido pacto. Pobres e negros, notadamente, não parte do pacto (Nascimento, 2010, p. 49).
\end{abstract}

A realidade brasileira é extremamente desigual, principalmente quando estamos discutindo qualidade de ensino público e privado. No momento do vestibular, os candidatos que são oriundos de ensino privado e possuem condições econômicas melhores, não só ingressam nas melhores Universidades, como nos cursos que são considerados de maior prestígio social. Enquanto os alunos vindos do ensino público e moradores de periferia, mal conseguem ingressar nas universidades e os que conseguem, têm muita dificuldade em permanecer. Para tanto, Zago (2008) nos traz que,

A origem social exerce forte influência no acesso às carreiras mais prestigiosas, pois a ela estão associados os antecedentes escolares e uma série de investimentos que se transformam em credenciais com peso não negligenciável nos processos seletivos (aulas particulares, viagens, cursos de língua estrangeira, intercâmbios culturais, para citar alguns exemplos). Mas a influência não é apenas resultado dessas estratégias objetivas, mas também de um conjunto de 
disposições, isto é, de hábitos que direcionam a "escolha" do curso entre outras práticas (Zago, 2008, p. 163).

Para tentar minimizar as desigualdades sociais que distanciam o aluno oriundo de classes populares de uma vaga na Universidade e ampliar as suas possibilidades, os CPVC's surgem numa perspectiva de contribuir para que a população economicamente desfavorecida tenha oportunidade de sucesso no ingresso e permanência no que diz respeito ao ensino superior.

Podemos dizer que a condição de desigualdade de acesso, a impossibilidade da igualdade de oportunidade - desigualdade de renda, raça, etc. - que se reproduz no campo da educação superior é uma problemática para os alunos mais pobres. Sabemos que grupos com melhores condições econômicas investem mais em educação, esses possuem mais chances de ingresso nas universidades, principalmente nas públicas, de acordo com Zago (2008, p.163), "As desigualdades são, portanto ampliadas também pelo crescimento dos investimentos educativos por parte das famílias em condições de fazê-lo se, como estes são diferenciados pelo lugar que ocupam no espaço social, aumentam as distâncias entre os grupos sociais".

Nesse contexto, os alunos economicamente desfavorecidos, estão excluídos deste processo, pois não tiveram chances de investir em um ensino básico de qualidade, buscando assim, os CPVC's, para que possam, mesmo que tardiamente, resgatar alguns conhecimentos que deveriam ter sido oferecidos no momento da vida escolar desses alunos.

De acordo com depoimentos das entrevistadas, uma das maiores dificuldades foi terem vindo do ensino público, devido suas deficiências, pois há uma defasagem no ensino e, assim, tiveram problemas em assimilar o conhecimento ofertado nas aulas do PVCSLRF. Mesmo conseguindo ultrapassar as barreiras das desigualdades e com as políticas de educação criadas para minimizá-las, financiamento estudantil, bolsas de estudos, entre outras, continuam atrás na corrida pela vaga no ensino superior.

A análise das características sociais, econômicas e culturais do público que reivindica um lugar nos cursos pré-vestibulares para aumentar suas chances nos concorridos vestibulares, especialmente públicos, mostra assim as outras facetas da exclusão. A expansão do ensino, nos moldes como vem se realizando, não tem favorecido aqueles que não podem custear uma formação em instituições privadas, ainda que existam políticas de financiamento estudantil e concessão de bolsas (Zago, 2008, p. 164). 
Levando em consideração as desigualdades vividas pelas classes populares e pelos grupos sociais historicamente excluídos do acesso ao ensino superior, os CPVC's se mantêm ativos, na condição de melhorar e ampliar o acesso desses grupos as Universidades, além de propor uma mudança social efetiva na vida dessas pessoas por meio da educação. $O$ que se propõe nos CPVC's, além de tudo o que foi dito anteriormente, é a universalização do acesso ao ensino superior e garantir que a população mais empobrecida tenha possibilidade de acessar um direito que é básico, o direito à educação. Para Nascimento (2010), os Pré-Vestibulares Comunitários,

(...) desenvolvem um trabalho que, além do ensino de conteúdos para os exames vestibulares, produzem demandas, questionamentos, reivindicações e propostas que vêm forçando a constituição de processos de universalização de acesso ao ensino superior em particular e da universalização de direitos de uma forma mais geral (Nascimento, 2010, p. 59).

O que podemos destacar nesta discussão, é que os Pré-Vestibulares Comunitários surgiram e estão, até hoje, atuando na perspectiva de diminuir as desigualdades sociais e minimizar os impactos da defasagem educacional que vivemos em nosso sistema público de educação, além de democratizar o acesso ao ensino superior. Os CPVC's atuam também, em diferentes vertentes, como dito anteriormente, em suas primeiras propostas, ainda enquanto PVNC, contribuíram para a formulação de políticas públicas, como as de ação afirmativas, que discutiremos no próximo capítulo.

\section{2}

\section{O Pré-Vestibular Comunitário São Luiz Rei de França - A Sua Gênese}

Os pré-vestibulares comunitários são espaços de educação, disseminação de conhecimento, além de ter como centralidade a inclusão dos alunos das camadas populares nas Universidades. O PVCSLRF ${ }^{3}$ é um exemplo desta atuação comunitária, ele iniciou as suas atividades em 2005 e as encerrou no ano de 2010. O objetivo principal do curso era a inserção dos jovens moradores de Costa Barros no ensino superior. O CPVC não tinha sede própria, assim, ficava

\footnotetext{
${ }^{3}$ Para melhor desenvolver esse capítulo, fizemos um pequeno histórico do Pré-vestibular São Luiz Rei de França, curso no qual realizamos nossa pesquisa. Para remontar a história do PVCSLRF, entrevistamos dois coordenadores, que puderam nos contar um pouco sobre como foi a gênese do curso.
} 
alocado nas dependências da Paróquia São Luiz Rei de França, situada no bairro acima citado 4 .

Segundo depoimento de um dos Coordenadores, o Pré-Vestibular nasceu a partir da ação de cinco membros da paróquia, que posteriormente, se tornaram coordenadores do CPVC.

Basicamente, o pré-vestibular é iniciado com o desejo e ação de cinco jovens da comunidade e membros da Paróquia São Luiz Rei de França, estes mesmos jovens, viriam a ser coordenadores do curso, uma vez que ele é estabelecido. Alguns desses, além de coordenadores, também eram professores. O trabalho da coordenação compreendia acompanhar os alunos, organizar e preservar o espaço de aula (sala cedida pela igreja), montar grade horária, divulgar o pré-vestibular, tanto em busca de alunos quanto de professores, replicar/preparar o material dado pelos professores para os alunos, acompanhar datas importantes das faculdades e repassar aos alunos (isenção, inscrição, provas); organizar passeios culturais e aulas ao ar livre (Coordenador do PVCSLRF).

Para que o CPVC se mantivesse ativo, não somente os coordenadores contribuíam com a organização e preparação do ambiente e das aulas, mas também alguns alunos auxiliavam com a dinâmica de organização, captação de professores, organização da sala de aula, cronograma, grade com os horários, controle de faltas dos alunos, etc.

O Pré-vestibular Comunitário São Luiz Rei de França tinha como protagonistas não somente seus coordenadores, mas também seus alunos e professores, que auxiliavam dando aulas de forma voluntária, esses, de uma maneira geral eram moradores da região ou chegavam por indicação de alunos ou até mesmo de outros professores. Essa afirmação fica ainda mais evidente na fala de um dos coordenadores, segue trecho abaixo:

O pré-vestibular precisava da ajuda de todos para funcionar, alunos, professores e coordenação. Alunos (jovens da igreja) mais próximos dos coordenadores eram responsáveis por abrir a sala junto com os coordenadores, um dos coordenadores era responsável por produzir o material impresso.

Havia uma escala, no fim de semana, para realização de limpeza da sala, uma das coordenadoras também fazia café em casa e levava para alunos e professores. Além disso, os coordenadores estavam atentos às datas dos vestibulares e pedidos de isenção de inscrição. Muitas faculdades aceitavam inscrições de pedidos de isenção por pré-vestibular, então cada coordenador era responsável por uma ou duas faculdades, era separada e conferida a documentação e então levávamos a Universidade (Coordenador do PVCSLRF).

O Pré-vestibular São Luiz Rei de França tinha como principal objetivo contribuir para o acesso dos jovens, que eram moradores do bairro (Costa Barros)

\footnotetext{
${ }^{4}$ A Paróquia São Luiz Rei de França está localizada na Estrada Botafogo n ${ }^{410}$, Costa Barros, Rio de Janeiro- RJ
} 
e não teriam condições de pagar por um curso privado e concorrer a uma vaga na Universidade, principalmente por serem alunos oriundos da rede pública com um histórico, que como sabemos que em alguns casos é precário e deficiente. Sobre a capacitação de alunos pobres/negros para ingresso no ensino superior, Brito e Gonçalves (2017) nos afirma que,

Os pré-vestibulares comunitários ou populares tinham como proposta inicial capacitar estudantes pobres e negros a realizarem o exame de admissão ao curso universitário. Na época do surgimento e fortalecimento desses cursos, na década de 1990, o vestibular era a única forma de ingresso na universidade (Brito; Gonçalves, 2017, p. 197).

Em um bairro como Costa Barros, que basicamente é constituído por favelas e os serviços públicos não chegam de maneira satisfatória e principalmente de qualidade, como os serviços de saúde, educação, segurança pública, habitação, saneamento básico, etc. Os alunos chegam à fase do vestibular com uma base educacional defasada, fazendo com que não tenham condições, devido ao seu histórico educacional, de ingresso nas Universidades. Para tanto, o Pré-Vestibular Comunitário São Luiz Rei de França surgiu com uma proposta de auxiliar estes jovens oriundos da classe trabalhadora, a ingressar no ensino superior e contribuir com uma maior democratização do ensino.

Sobre a questão da defasagem educacional dos alunos do CPVC, um dos coordenadores nos traz a seguinte fala:

Havia uma defasagem muito grande entre eles, alunos que se formaram no ensino médio sem ver nem metade do programa, alunos com problemas de leitura e escrita. O pré-vestibular de certa forma foi muito mais que somente um pré, foi um portal para os jovens de Costa Barros para um outro mundo de possibilidades (Coordenador do PVCSLRF).

Os alunos do CPVC não pagavam mensalidade, mas os que podiam, pagavam uma pequena taxa para manutenção do curso, para ajudar com a passagem dos professores, cópias, pagamentos de taxas de inscrição, etc.

Outro ponto importante em relação ao PVCSLRF, é o fato deles terem levado seus alunos a "ocuparem a cidade", pelos passeios culturais, indo a lugares históricos, museus, apresentando o espaço da universidade, etc. Conforme relato do coordenador abaixo:

Com o decorrer do tempo, vimos que podíamos melhorar a forma de ensinar, podíamos levar cultura e aprendizado a eles, podíamos dar e mostrar algo muito maior a eles. A vida não precisa ficar presa aos becos e muros de tijolos, então, passamos a fazer passeios culturais com eles, sempre com algum coordenador e 
professor juntos. Então levávamos os alunos a locais históricos no Cento da cidade, museus, teatros, procurávamos também sempre debater questões sociais e problemas do bairro com eles, bem como conversar sobre carreira e profissões. Algumas faculdades faziam uma vez por ano um evento de apresentação do espaço universitário e de seus cursos e nós sempre fazíamos a inscrição deles (Coordenador do PVCSLRF).

De acordo com relatos dos coordenadores, o início e formação do PVCSLRF foi basicamente por membros da própria igreja, como afirmado anteriormente, tudo iniciou-se com os encontros que aconteciam entre os jovens da própria paróquia e surgiu da preocupação dos mesmos em proporcionar um ambiente de debate e acolhimento que não havia no bairro naquele momento.

Não constam muitos documentos datados do período, pois, no ano de 2012, a paróquia foi demolida e reconstruída e todos os arquivos referentes ao CPVC foram descartados, portanto, a partir das entrevistas que fizemos com as exalunas e os ex-coordenadores, conseguimos fazer uma reconstrução também da história e da memória do Pré-vestibular Comunitário São Luiz Rei de França. Para remontar a história do CPVC, trazemos abaixo um pouco da fala de um dos entrevistados e ex-coordenador do CPVC:

Costa Barros, como sempre, um local muito carente e com falta de opções de lazer e espaços seguros e sadios para convivência, tem na igreja um local excelente para encontros e bate-papos. Os encontros dos jovens não se limitam apenas as obrigações da igreja mas era um local para os mais diversos debates. (...) Em um desses debates, discutíamos que era preciso levar esperança a esses jovens, gerar uma expectativa de melhora para todo o bairro. Pode parecer clichê mas não é, é realidade, o único caminho que tínhamos era educação. (Coordenador do PVCSLRF).

E segue o relato sobre a gênese do CPVC:

No grupo, tínhamos dois jovens que haviam recentemente entrado para faculdade e ambos engajados com trabalhos sociais dentro e fora da comunidade, além de possuírem memória afetiva do pré-vestibular que havia funcionado tempos atrás no mesmo local. Soma-se a isso o fato de vivenciarem o surgimento de prés comunitários em outros locais, então, por que não ter um em Costa Barros? Neste momento, já éramos um grupo onde tínhamos os próprios professores voluntários, jovens que viriam a ser alunos, professor formado e que já dava aula em pré, todos no mesmo grupo de debate (Coordenador do PVCSLRF).

O entrevistado ainda ressalta como era a infraestrutura do curso no início e como foram acontecendo as melhorias, segue abaixo relato:

O pré-vestibular começou carente ainda de algumas estruturas como ventiladores, que aos poucos fomos melhorando e sempre que possível íamos investindo na infraestrutura. Combinamos com o pároco que por não pagarmos nada a igreja, qualquer benfeitoria feita ficaria para a mesma, caso o pré viesse acabar (Coordenador do PVCSLRF). 
Devemos destacar que todos de alguma maneira auxiliaram com o que, de alguma forma, foi contribuir para a reconstrução da história e da gênese do PVCSLRF. Trouxeram em suas falas a importância desse curso não só para as ex-alunas, mas também para o bairro, durante o seu período de vigência.

O Pré-vestibular Comunitário São Luiz Rei de França foi de extrema importância para que os alunos da classe trabalhadora e em situação de desigualdade social, moradores de Costa Barros, pudessem ingressar no ensino superior. Mesmo com o pouco preparo das Universidades em receber esses grupos, que contam principalmente com a falta de acesso à tecnologia, falta de recursos financeiros, defasagens educacionais, etc. os CPVC's são, de certa maneira, o início da perspectiva de uma vida acadêmica para esses alunos.

Não é por acaso que os cursos pré-vestibulares populares reclamam e denunciam que a universidade pública no Brasil é espaço de exclusão, com cultura e processos internos que dificultam a entrada e a permanência, em seu âmbito, de estudantes oriundos dos setores populares. Não é por acaso também que a proposta de cotas para negros, indígenas, estudantes pobres e estudantes oriundos de escolas públicas têm o apoio da maioria dos cursos pré-vestibulares populares. Na verdade, os cursos pré-vestibulares populares constituem a base social sobre a qual se fundamentam as propostas de ação afirmativa no ensino superior (Nascimento, 2010, p. 61,62).

Assim como muitos CPVC's, o Pré-Vestibular Comunitário São Luiz Rei de França teve sua base na Igreja Católica, esta historicamente tem diversos trabalhos na área social, como nos traz Assis (2016, p. 41) "A Igreja Católica é uma instituição com um histórico na área social que merece ser destacado". Muitos CPVC's não possuem sede própria, então, nesse sentido, a igreja católica fortalece esses movimentos, não somente cedendo espaço para que as aulas aconteçam, mas também apoiando e servindo como parceira desses cursos, visto que a maioria dos CPVC's não possuem uma renda fixa para garantir sua existência.

Outro ponto que podemos destacar, é que muitos dos membros fundadores/Coordenadores dos CPVC's frequentam as paróquias em que os mesmos estão alocados e não foi diferente com o Pré-Vestibular Comunitário São Luiz Rei de França, mais uma vez, lembrando que seus fundadores participavam das atividades da Paróquia, incluindo pastorais sociais, pastoral da juventude, pastoral da saúde, etc. Assim, esses membros contribuíram para perpetuar o compromisso da igreja para com os mais pobres e fragilizados. 
Nas décadas de 70 e 80, a estrutura da Igreja Católica sofreu grandes alterações, principalmente a partir de novas orientações religiosas. Segundo Solange Andrade, as mudanças que a Igreja Católica começou a sofrer surgiram a partir da influência do Concílio Vaticano II (1962-1965) e das Conferências Episcopais de Medellín (1968) e Puebla (1979). A Igreja Católica latino-americana assumiu uma nova direção que, primeiro em Medellín e, depois, em Puebla, inspirada no Concílio Vaticano II, fez sua Opção pelo Pobre, o que ocorreu por volta da década de 1970, quando alguns membros do clero acabaram se envolvendo na luta pelos direitos humanos, pelo direito à terra, enfim, tudo o que estivesse ligado ao homem marginalizado (Andrade, 2006, p. 5 apud Clapp, 2008, p. 133,134).

Clapp (2008), nos traz que "é uma nova visão do papel da lgreja e de uma prática cristã, que significou uma mudança de orientação para ser católico no mundo". Esse olhar para os mais pobres e para as desigualdades sociais existentes são fundamentais, principalmente para os trabalhos que são realizados nos espaços das igrejas, como é o exemplo dos CPVC's.

A ligação direta do PVCSLRF com a igreja católica é notória, não somente pelo fato de estar alocado dentro do espaço da Paróquia, mas também pelo fato de ambos, em suas singularidades, buscarem por igualdade social e contribuírem na luta por direitos dos mais pobres e excluídos socialmente, por este motivo torna-se relevante citar nesta pesquisa como os CPVC's e a igreja caminharam juntos nesse sentido.

Os Pré-Vestibulares Comunitários contribuíram para questionar o Estado e a sociedade a respeito das desigualdades sociais e até mesmo educacionais existentes em nosso país, principalmente sobre a ausência de negros e pobres no espaço universitário, assim passaram a reivindicar o ingresso desses grupos no ensino superior e lutaram pela implementação de políticas de ações afirmativas como forma de democratizar o acesso ao ensino superior.

Desta maneira, diante de tudo o que já foi exposto, trataremos no próximo capítulo sobre como a desigualdade social e a pobreza contribuem para o não acesso da população que vive em condições de exclusão e vulnerabilidade no ensino superior. 


\section{3}

\section{Desigualdade Social e Pobreza}

Pretendemos analisar neste capítulo, alguns aspectos das desigualdades sociais, e até mesmo da pobreza existentes no Brasil, dentre tais desigualdades também estão as de gênero, de raça, de renda e educacionais. A proposta é apontar que, mesmo diante de uma democracia baseada nos direitos sociais, civis e políticos, ainda existem grupos que não se beneficiam de maneira igualitária desses direitos. Assim, os grupos privilegiados se mantêm com seus direitos reservados, enquanto uma boa parcela da população fica à margem deles.

Entendemos que desigualdade social está intimamente ligada às diferenças no que diz respeito à distribuição de renda, porém, vai para além da questão de renda, para Campello e Gentili (2018, p. 13), "A desigualdade social é sempre uma relação política, passível de ser enfrentada pela ação do Estado e afirmada pelas lutas coletivas por direitos, cujo efeito democrático pode ser desestabilizador de privilégios historicamente reproduzidos pelas elites".

As desigualdades sociais são uma lacuna que separa os mais pobres dos mais ricos, que faz com que exista um abismo no que diz respeito à distribuição de recursos, visto que a riqueza se concentra na mão de poucos, enquanto uma enorme parcela da população vive com o mínimo possível.

Devemos enfatizar que na atual conjuntura ${ }^{5}$, tivemos um acirramento da pobreza, da exclusão e das desigualdades sociais. A pobreza está intimamente ligada à desigualdade social, e é por ela que a população menos favorecida fica à margem de uma série de privilégios e distantes de seus direitos.

(...) a pobreza assume no Brasil uma dimensão abrangente, evidenciando um quadro amplo para intervenção de políticas de corte social, entendendo que as políticas sociais, para serem mais eficazes, devem estar articuladas a políticas macroeconômicas que garantam um crescimento econômico sustentado; a geração de emprego; a elevação da renda proveniente do trabalho e, sobretudo, a redistribuição de renda ainda altamente concentrada no Brasil (Silva, 2010, p.156).

\footnotetext{
${ }^{5}$ Não podemos deixar de citar aqui, mais uma vez, o contexto da pandemia do novo coronavírus, o alto índice de desemprego e consequentemente da pobreza e das desigualdades sociais, além do fato do atual Presidente da República Jair Messias Bolsonaro, eleito no ano de 2018, não realizar o devidos investimentos nas áreas de saúde, pesquisa, educação, etc. contribui para que essas desigualdades se intensifiquem. De acordo com Matta et al (2021) "Os desafios postos em relevo pela pandemia não são apenas sanitários. São socioeconômicos, políticos, culturais, éticos, científicos, sobremaneira agravados pelas desigualdades estruturais e iniquidades entre países, regiões e populações" (p. 17).
} 
Sabidamente as mulheres pobres, em via de regra que vivem em situação de desigualdade social, são inivisibilizadas e excluídas de seus direitos, de acesso a bens e serviços, etc., visto que vivemos em uma sociedade machista em que o modelo patriarcal ainda nos dias atuais faz parte dos moldes e do imaginário social. Por este motivo, este capítulo irá tratar de como a desigualdade social e a pobreza têm rebatimentos diretos na vida das ex-alunas do PVCSLRF.

\title{
3.1. Desigualdade Social e Pobreza e seus Rebatimentos na Vida das Ex- Alunas do Pré-Vestibular Comunitário São Luiz Rei de França
}

Como afirmado anteriormente, "a pobreza no Brasil decorre, em grande parte, de um quadro de extrema desigualdade, marcado por profunda concentração de renda" (Silva, 2010, p. 156). Portanto, podemos dizer que o Brasil não é um país pobre, mas sim, de pessoas pobres. Essas, que vivem marginalizadas, invisibilizadas e esquecidas pelo Estado.

Quando falamos que existem pessoas e/ou grupos que estão à margem, afirmamos que estão em uma situação de exclusão social. Para Silva (2010, p. 156), "Essa categoria é utilizada para designar processos que alcançam camadas da população, em razão de mudanças que produzem acúmulo progressivo de dificuldades, decorrentes principalmente do desemprego prolongado e da precarização do trabalho".

Não podemos falar de pobreza e desigualdade social, sem antes falar do sistema capitalista no qual estamos inseridos, com base em Silva (2010),

\begin{abstract}
O entendimento é de que o sistema de produção capitalista, centrado na expropriação e na exploração para garantir a mais valia, e a repartição injusta e desigual da renda nacional entre as classes sociais são responsáveis pela instituição de um processo excludente, gerador e reprodutor de pobreza, entendida enquanto fenômeno estrutural, complexo, de natureza multidimensional, relativo, não podendo ser considerada como mera insuficiência de renda. É também desigualdade na distribuição de riqueza socialmente produzida; é não acesso a serviços básicos; à informação; ao trabalho e a uma renda digna; é não participação social e política. Esse entendimento permite desvelar valores e concepções inspiradoras das políticas públicas de intervenção nas situações de pobreza e as possibilidades de sua redução, superação ou apenas regulação (Silva, 2010, p. 157).
\end{abstract}

Sabe-se que, no Brasil, os níveis de pobreza e desigualdade social são elevadíssimos, muitos grupos ainda vivem excluídos, em situação de vulnerabilidade social e principalmente de exclusão. Esses grupos, podemos citar aqui, negros, mulheres, população LGBTQIA+, indígenas, etc., estão em situação 
de desigualdade têm mais dificuldade no acesso à garantia de direitos, que lhes foram historicamente negados, além de estarem mais expostos aos efeitos dessa desigualdade, visto que seu acesso a bens e serviços são historicamente restritos.

Relembrando, pretendemos neste capítulo demonstrar como as questões relacionadas à desigualdade social, educacional, de renda, racial, também interferem no cotidiano das ex-alunas do PVCSLRF e se torna mais alarmante, quando falamos de mulheres que são pobres/faveladas, no caso dessas, que são/foram moradoras de Costa Barros.

As desigualdades de gênero, mesmo atualmente, são marcantes no mundo e na sociedade brasileira, as mulheres que vivem em condições de desigualdade social, vivem uma relação de submissão e subjugação recorrentes em nossa sociedade. Durante muitas décadas, o lugar dessa mulher era apenas no ambiente privado, o que Ihe restava até então, era cuidar da casa e dos filhos, enquanto, para os homens, havia a liberdade da vida pública. Esse quadro começou a ter mudanças significativas, a partir dos movimentos feministas, como afirma Lisboa (2017),

\begin{abstract}
Fruto dos movimentos feministas da década de 1970, muitas mulheres acordaram para vários tipos de opressão a que estavam sujeitas, independentemente das diferenças de classe, raça/etnia, religião ou cultura. Nesse sentido foram construindo uma consciência comum sobre a necessidade de colocar-se uma ao lado da outra para apoiarem-se mutuamente em relação ao domínio patriarcal que se caracteriza por um complexo cultural formado pelo sexismo, a misoginia, o machismo, a homofobia, bem como pelo classismo, racismo, a xenofobia e todos os demais preconceitos que conduzem à exclusão e à negação da diferença (Lisboa, 2017, p. 25).
\end{abstract}

Trataremos aqui das diversas facetas das desigualdades sociais em nosso país, algumas delas são as questões relacionadas à desigualdade de gênero e principalmente como essas desigualdades rebatem diretamente nas mulheres mais pobres.

É inevitável pensar que atualmente as mulheres alcançaram diversos direitos e privilégios, que historicamente já eram de benefício dos homens, porém, devemos refletir também, que as mulheres pobres e periféricas não gozam desses privilégios (que podemos citar como exemplo, educação superior, uma boa colocação no mercado de trabalho, acesso à cultura, salário digno, etc.), que de maneira geral, abraçam apenas as mulheres brancas e das classes mais abastadas, as demais, permanecem na marginalidade. Entendemos que, "por definição, as principais beneficiárias são aquelas que já contam com 
consideráveis vantagens sociais, culturais e econômicas. Todas as demais permanecem presas no porão" (Arruzza; Bhattacharya; Fraser, 2019, p. 38).

Devemos pensar, que as mulheres periféricas, falamos aqui de uma maneira geral das mulheres moradoras da favela, estão em desvantagem no que diz respeito aos privilégios já conquistados por mulheres de outras camadas sociais.

A mulher moradora da favela, em especial as moradoras do conjunto de favelas de Costa Barros, antes de saírem para trabalhar, deve "driblar" todo o sistema de violência imposto pela localidade onde moram, devem tentar sobreviver a uma infinidade de violências e privações antes mesmo de sair na rua, começar sua jornada de trabalho antes de sair de casa (devido a suas múltiplas funções), atravessar a cidade por meio de transporte público precário para criar os filhos de outras mulheres, enquanto os seus "se criam" sozinhos. Assim, por esses e por inúmeros outros motivos, devemos pensar essas mulheres, colocálas em pauta e como protagonistas de suas histórias.

A exploração, a dominação, e a opressão são cotidianas na vida das mulheres pobres e se intensificam ainda mais se tratando das mulheres negras. A exploração, muitas vezes, se inicia em casa, quando não há uma divisão justa das tarefas domésticas, essas que são invisibilizadas e não remuneradas e só aumentam quando essa mulher sai de seu ambiente privado e vai para o mercado de trabalho, no qual a desigualdade salarial em relação aos homens, seus direitos trabalhistas são o tempo todo violados e quase impossíveis de serem reivindicados.

A dominação masculina, seja no âmbito público ou privado, ainda é uma realidade e a opressão, seja pela violência urbana ou doméstica, ainda é um ponto que precisa ser discutido e problematizado para pensarmos essas mulheres. Pensá-las em suas múltiplas questões é urgente e de extrema importância, refletir as desigualdades não apenas de gênero, mas também culturais e econômicas deve ser pauta imediata.

Nos anos de 1970, tivemos uma onda feminista, em que muitos direitos foram questionados e conquistados, mas o que devemos questionar nos dias de hoje é: o feminismo que existe atualmente, abraça todas as mulheres? Quais mulheres estão fora, marginalizadas desta onda feminista? O feminismo tem, de fato, emancipado as mulheres pobres? Os corpos negros, especialmente das mulheres, continuam sendo submissos e expostos aos trabalhos mais precários?

O sistema capitalista vive da exploração do trabalho, dos que não são os detentores do capital, ou seja, os que vivem na base da pirâmide social, que são 
os mais atingidos por tal exploração, tratamos aqui das ex-alunas do PVCSLRF, que são mulheres pobres e periféricas, essas que são as mais atingidas e exploradas. Para essas mulheres, devemos pensar no feminismo que abrace a todas e contribua para mudanças verdadeiras e concretas no cotidiano delas, e que consigam se emancipar cultural, política e economicamente e saia da condição de exploração. Arruzza, Bhattacharya e Fraser (2019, p. 47) propõem o feminismo para os $99 \%$, elas afirmam que pretendem "(...) identificar e confrontar diretamente a verdadeira origem da crise e da miséria, que é o capitalismo".

Ainda de acordo com as autoras,

Muitas pessoas sabem que as sociedades capitalistas são, por definição, sociedades de classes que permitem a uma pequena minoria acumular lucros por meio da exploração de um grupo muito maior, que deve trabalhar por salários. O que é menos amplamente compreendido é que sociedades capitalistas também são, por definição, a origem da opressão de gênero. Longe de ser ocidental, o sexismo está entranhado em sua própria estrutura (Arruzza; Bhattacharya; Fraser, 2019, p. 51).

Dito isto, seguimos com nossa análise a respeito das desigualdades de gênero, afirmando que não é possível pensar a sociedade capitalista e a relação das mulheres pobres neste contexto, sem antes fazer uma reflexão crítica sobre a realidade delas, que historicamente são subjugadas e colocadas em um patamar inferior aos dos homens. O capitalismo não inventou essa relação de submissão, pois esta já existia em outros modelos de sociedade, somente o intensificou. Como afirma Arruzza, Bhattacharya e Fraser (2019),

O capitalismo certamente não inventou a subordinação das mulheres. Esta existiu sob diversas formas em todas as sociedades de classe anteriores. O capitalismo, porém, estabeleceu outros modelos, notadamente "modernos", de sexismo, sustentados pelas novas estruturas institucionais. Seu movimento fundamental foi separar a produção de pessoas da obtenção de lucro, atribuir o primeiro trabalho às mulheres e subordiná-lo ao segundo. Com esse golpe, o capitalismo reinventou a opressão das mulheres e, ao mesmo tempo, virou o mundo de cabeça para baixo (Arruzza; Bhattacharya; Fraser, 2019, p. 51-52)

O que podemos dizer é que, mesmo com diversas conquistas por parte das mulheres, por meio de reivindicações e questionamentos que deram início com o movimento feminista, mesmo que, atualmente, elas sejam maioria nas Universidades e que o mercado de trabalho se abriu de forma ampla para este grupo, o que devemos questionar é, a que custo as mulheres pobres/faveladas/periféricas conseguem não somente ingressar, mas permanecer e concluir seus cursos de nível superior? Como foi sua trajetória antes, durante e após a conclusão do curso? Qual o perfil dessas mulheres? Após a conclusão de 
seus cursos universitários, essas mulheres conquistam algum tipo de mobilidade social $^{6}$ ?

Quando falamos de desigualdade de gênero, trajetória e mobilidade social das mulheres moradoras de favela, em especial das ex-alunas do PVCSLRF, se requer que analisemos também se houve promoção social na vida delas, não somente econômica, mas também social, cultural e geracional, no sentido de tentarmos entender se a formação superior trouxe impactos na realidade desse grupo? Em relação às suas mães, essas mulheres elevaram seus patamares de vida? Conquistaram maior grau de escolaridade? Conquistaram melhores posições no mercado de trabalho? Além de uma série de outros questionamentos.

Ao falarmos de estudantes pobres, essas já partem de uma realidade econômica desfavorável, contudo, apesar do abismo social que separam essas mulheres de seus objetivos individuais, profissionais e acadêmicos, até mesmo da ascensão social e econômica que teoricamente almejam, a educação ainda é o caminho mais seguro e eficaz para que isso aconteça.

A ascensão social deve, portanto, mostrar um resultado claro através de diversos indícios que sinalizam o processo de acumulação financeira. É, portanto, uma posição futura imaginada, buscada e idealizada pelos indivíduos, já que os mesmos jamais estiveram nesta posição e habitualmente tem pouca convivência com pessoas de classes sociais altas (Larrubia, 2016, p. 12).

Outro aspecto da desigualdade social que devemos analisar, é a desigualdade de renda, visto que a sociedade Brasileira, tem a desigualdade como elemento estruturante.

Segundo Campello et al. (2018, p. 55) "O Brasil vivenciou uma inédita e sistemática queda da desigualdade no período recente, mas continua a ocupar a posição de um dos países mais desiguais do mundo". A desigualdade possui diversas dimensões, não apenas no que diz respeito à renda, seria contraditório $e$ limitado dizer, que essa é a única maneira de mensurar desigualdade, visto que temos diversos outros fatores que interferem neste quesito.

\footnotetext{
${ }^{6}$ Sobre mobilidade social, Cordeiro (2013, p. 308-309), nos traz que “(..) entende-se mobilidade social como mudanças no status social, como o estudo da mobilidade vertical que se refere a uma relação entre a posição social do presente com a do passado, identificando como as pessoas se distribuem nos diversos níveis da estrutura social através do tempo, o peso da herança cultural, dos recursos individuais e das oportunidades econômicas e sociais proporcionadas pela sociedade em determinado período de tempo. O estudo da mobilidade examina também os impactos dos movimentos individuais e grupais sobre a estrutura social, atentando para a diminuição e expansão das camadas sociais. A mobilidade ascendente permite revelar a promoção social que as pessoas estão vivenciando em diversas áreas da vida, entre elas a educacional e econômica. Uma sociedade que não tem mobilidade seria uma sociedade estagnada e reprodutora da estrutura social”.
} 
A mensuração de desigualdade mais conhecida é a da concentração de renda apurada pelo Coeficiente de Gini. Ela aponta a diferença entre os rendimentos dos mais pobres e dos mais ricos e vem cumprindo um papel inegável, ao expor uma das faces mais estruturantes do fenômeno, a desigualdade de renda. Entretanto, apresenta limitações por olhar um único aspecto do problema: a renda monetária (Campello et al., 2018, p. 55).

Devemos levar em conta, outros aspectos que possam medir a desigualdade no Brasil, pois analisando somente através da questão da renda, não alcança de forma satisfatória boa parte da população, visto que existe um grupo que vive excluído de bens e serviços produzidos pela sociedade, além de terem seu acesso a direitos constantemente negados, falamos aqui de uma camada densa da população, que vive à margem da riqueza produzida socialmente. Quando falamos que medir desigualdade social apenas pelo aspecto da renda, não é eficaz, não estamos tirando a importância desta medida, o que estamos dizendo é que, numa sociedade como a nossa, deve-se levar em conta aspectos como, desigualdade de raça, classe, gênero, educacional, entre outras.

É absolutamente importante discutir a desigualdade do ponto de vista da renda, olhando o estoque de capital e o patrimônio acumulado pelos ricos. No entanto, o olhar sobre a desigualdade não pode ignorar a necessidade de superar a assimetria de acesso a bens e serviços. Uma parcela expressiva da população vem vivendo à margem de condições mínimas de vida. Elevá-las a um patamar de dignidade não pode ser considerado um valor secundário no debate sobre desigualdade. Esse tema é, sem dúvida, um dos mais relevantes aprendizados e evidências do período de conquistas sociais que o Brasil viveu recentemente (Campello et al., 2018, p. $56)$.

As necessidades da população vão para além da questão econômica, não que essa seja menos importante, mas se faz necessário que se criem políticas, para que os mais pobres tenham acesso a serviços que lhes vêm sendo negados ao longo do tempo. Ter acesso a bens e serviços, neste caso, também significa que a população pobre, vai viver em condições menos desiguais, por isso a importância de humanizar o nosso olhar sobre este debate,

Assim, queremos adicionar ao escopo da análise econômica uma perspectiva mais humanizada sobre as faces que a desigualdade pode assumir em uma sociedade como a nossa, agregando empatia ao debate e ampliando uma visão crítica que apoie a compreensão sobre as múltiplas situações de privações de direitos e as políticas que podem contribuir estrategicamente para a mitigação das desigualdades. Há questões determinantes aqui. $\mathrm{O}$ acesso - ou o não acesso - à água, saneamento, energia, educação, saúde, moradia e bens de consumo, como geladeira, telefone, entre outros, não são dimensões periféricas da desigualdade. A urgência e a prioridade de acesso a esses direitos aos mais pobres podem ocorrer 
concomitantemente às mudanças estruturais que demandam tempo de implementação, ou seja, são a longo prazo (Campello et al., 2018, p. 56).

Para Campello et al. (2018, p. 16), "o que para parte da população é um bem de consumo, para os mais pobres é um ‘não direito' e um limitante, muitas vezes estrutural, às suas oportunidades de desenvolvimento e à possibilidade de uma vida digna e segura". Viemos de um histórico em que no nosso país, o pobre só 'tem direito, a não ter direitos', e essa questão se aprofunda e se desencadeia marcas ainda mais preocupantes, quando adicionamos à equação a questão de raça e gênero. Grupos que vivem em situação de desigualdade social veem constantemente seus direitos negados e estes vêm sendo atacados pelas elites, que não desejam que seus privilégios sejam diminuídos ou retirados e quem sabe igualados aos dos menos favorecidos.

Os aspectos da pobreza e da desigualdade social, vão para além da renda, como já dito anteriormente, estamos tratando aqui, de uma série de privações que os mais fragilizados, principalmente as mulheres, enfrentam em nossa sociedade. Existe uma vulnerabilidade no que diz respeito aos menos privilegiados, que, historicamente, vivem marginalizados e invisibilizados pelo poder público. É uma camada da população 'inexistente', que de uma maneira geral, não costuma ser vista por aqueles que já gozam de direitos, bens e serviços, e quando encontram formas de resistir e lutar, incomodam profundamente a elite e os governantes.

Podemos citar também as desigualdades educacionais, reforçando que o Brasil está longe de ser modelo em educação, a defasagem e a precariedade começa no ensino fundamental, perpassando pelo ensino médio e culminando no ensino superior, isso levando em consideração àqueles alunos das camadas mais pobres que chegam à Universidade, como é o caso das ex-alunas do PVCSLRF.

Diversas são as desigualdades que permeiam o ensino superior, como a dificuldade no acesso dos mais pobres e vulneráveis, não somente pela questão econômica, mas também pela falta de preparo e por uma vida inteira de um ensino que, muitas vezes, é precarizado e insuficiente para lhe garantir concorrer a uma vaga na Universidade. Não podemos deixar de mencionar também que a educação superior tem sido alvo de constante sucateamento e cortes em investimentos, por parte do atual governo federal ${ }^{7}$. Para Campello et al. (2018, p.

\footnotetext{
${ }^{7}$ O Governo do atual Presidente Jair Messias Bolsonaro, que venceu as eleições no ano de 2018, atualmente sem partido, tem deixado claro, não somente por meio de sua fala (também de sua equipe), mas também por intermédio de suas ações, que não pretende investir e incentivar a entrada da população pobre no ensino superior.

No ano de 2020, em meio a uma pandemia do novo Coronavírus, mesmo com as aulas suspensas, por conta do isolamento social, e os alunos (tanto de escolas públicas, quanto das privadas) tendo aulas online, o Ministro da Educação Abraham Weintraub, insistiu para que o ENEM (Exame
} 
18), "se há um consenso em estratégia para o desenvolvimento de um país, este é o investimento em educação. A manutenção da desigualdade em educação é um dos fatores que mais determinam a dinâmica de exclusão e a perpetuação da pobreza".

Sobre a desigualdade educacional, pode-se dizer que jovens oriundos de classes populares emergem de uma esfera excludente, onde os acessos são limitados, por este motivo Clapp Salvador (2016) nos traz que "vive-se um contexto de "cidadania restrita", em que parte da população não tem garantido seu direito à educação, à saúde, à alimentação de qualidade" (p. 148). Trata-se de uma parcela da população que vive à margem de seus direitos, inclui-se aqui principalmente o direito à educação superior. Assim, pode-se dizer que,

\begin{abstract}
Essa realidade se reporta as universidades brasileiras. A condição de uma cidadania incompleta se reproduz no campo da educação, especialmente no contexto da educação superior, em que apenas 13,9\% dos jovens brasileiros na faixa etária de 18 e 24 anos frequenta o ensino superior (IBGE, 2008), o que demonstra as dificuldades encontradas e os escassos mecanismos de acesso e permanência na educação Brasileira (Clapp Salvador, 2016, p. 148).
\end{abstract}

A chegada de jovens, oriundos de classes populares, como é o caso das ex-alunas do PVCSLRF, ao ensino superior também é uma questão a ser debatida, levando em consideração todo o histórico de uma educação pública que tem a recorrência de ser deficiente, principalmente quando oferecida pelo Estado. Mesmo diante de tais deficiências, a inserção dessas mulheres oriundas de classes populares numa universidade é uma vitória, mas essa inserção também deve ser problematizada, pois ainda nos dias atuais, o espaço universitário é um espaço hostil para os mais pobres e essencialmente comum para os mais ricos.

Mesmo com a criação de programas e políticas para democratização do acesso ao ensino superior nas últimas décadas, como afirmado anteriormente, ainda há um longo caminho a ser percorrido, pois muitos desses jovens permanecem fora da Universidade. Para Campello et al. (2018),

\footnotetext{
Nacional do Ensino Médio), não fosse adiado, pois segundo o Ministro, "o ENEM não foi feito para corrigir injustiças", porém, após muita pressão popular, no dia 19/05/2020, através do Projeto de Lei 1.277/2020, foi aprovado pelo Senado (Inclui § 1ํ-A ao art. 44 da Lei no 9.394 , de 20 de dezembro de 1996, para prever a prorrogação automática de prazos para provas, exames e demais atividade para acesso ao ensino superior em caso de reconhecimento de estado de calamidade pelo Congresso Nacional ou de comprometimento do regular funcionamento das instituições de ensino do país), o adiamento do Enem e assim, a matéria seguiu para a Câmara dos Deputados (Lemos, 2020).
} 
Uma barreira histórica para estudantes das escolas públicas começou a ser rompida pelos jovens que enfrentam os desafios da desigualdade social, no entanto ainda é apenas uma brecha, que não comporta contingentes massivos de estudantes de baixa renda. $O$ ensino superior continua sendo um espaço elitizado no Brasil (Campello, et al., 2018, p. 58- 59).

Vale destacar também o histórico familiar das ex-alunas do PVCSLRF, pois, em sua grande maioria, vieram de famílias que nunca pisaram ou sequer pensaram em pisar na Universidade, o que só reforça o nosso debate sobre desigualdades educacionais, tendo em vista que como não há nenhuma experiência familiar neste sentido, os incentivos para que jovens pobres ingressem na vida acadêmica são escassos. De acordo com Campello et al. (2018), "uma geração de jovens conquistou o lugar dos primeiros membros de suas famílias a terem acesso à Universidade. Em 2015, por exemplo, 35\% dos formandos que fizeram o Exame Nacional de Desempenho de Estudantes (Enade) eram os primeiros da família a serem diplomados" (Campello et al., 2018, p. 59).

A ideia central deste capítulo era relatar um pouco sobre os aspectos decorrentes da desigualdade social e da pobreza e seus rebatimentos na vida das ex-alunas do PVCSLRF. Afirmamos aqui que a desigualdade de gênero, a racial, a educacional e a de renda, fazem parte das diversas formas em que as desigualdades sociais se apresenta. 
4.

\title{
Políticas de Ações Afirmativas
}

As Políticas de Ações Afirmativas são destinadas à população que vive em situação de desigualdade social, e que de maneira geral, é constituída por pessoas negras, que vêm historicamente tendo seus direitos negados e vivendo em situação de exclusão, principalmente, no que diz respeito ao acesso à educação superior. Lembrando que as políticas de ações afirmativas vão para além da pobreza, pois são destinados a grupos historicamente discriminados e/ ou minorias. De acordo com o Ex-Ministro Joaquim Barbosa Gomes (2001),

\begin{abstract}
Começa a ingressar de maneira tímida _ et pour cause! na Academia brasileira o debate em torno de possíveis «medidas compensatórias» destinadas a promover a implementação do princípio constitucional da igualdade em prol da comunidade negra brasileira.

O tema é de transcendental importância para o Brasil e para o direito brasileiro, por dois motivos. Primeiro, por ter incidência direta sobre aquele que é seguramente o mais grave de todos os nossos problemas sociais (e que estranhamente todos fingimos ignorar), o que está na raiz das nossas mazelas, do nosso gritante e envergonhador quadro social - ou seja, os diversos mecanismos pelos quais, ao longo da nossa história, a sociedade brasileira logrou proceder, através das mais variadas formas de discriminação, à exclusão e ao alijamento, do processo produtivo consequente e da vida social digna, de um expressivo percentual de sua população (cerca de $45 \%$ do total): os brasileiros portadores de ascendência africana. Em segundo lugar, por abordar um tema nobre de direito constitucional comparado e de direito internacional, mas que é, curiosamente, negligenciado nas letras jurídicas nacionais, especialmente no âmbito do Direito Constitucional (Barbosa, 2001, p. 129).
\end{abstract}

As políticas de ações afirmativas estão diretamente ligadas ao princípio de igualdade ${ }^{8}$, no Brasil, é possível afirmar que grupos menos favorecidos ainda

\footnotetext{
8 "A noção de igualdade, como categoria jurídica de primeira grandeza, teve sua emergência como princípio jurídico incontornável nos documentos constitucionais promulgados imediatamente após as revoluções do final do século XVIII. Com efeito, foi a partir das experiências revolucionárias pioneiras dos EUA e da França que se edificou o conceito de igualdade perante a lei, uma construção jurídico-formal segundo a qual a lei, genérica e abstrata, deve ser igual para todos, sem qualquer distinção ou privilégio, devendo o aplicador fazê-la incidir de forma neutra sobre as situações jurídicas concretas e sobre os conflitos interindividuais. Concebida para o fim específico de abolir os privilégios típicos do ancien régime e para dar cabo às distinções e discriminações baseadas na linhagem, no «rang», na rígida e imutável hierarquização social por classes («classement par ordre»), essa clássica concepção de igualdade jurídica, meramente formal, firmou-se como idéiachave do constitucionalismo que floresceu no século XIX e prosseguiu sua trajetória triunfante por boa parte do século XX. Por definição, conforme bem assinalado por Guilherme Machado Dray, «0 princípio da igualdade perante a lei consistiria na simples criação de um espaço neutro, onde as virtudes e as capacidades dos indivíduos livremente se poderiam desenvolver. Os privilégios, em sentido inverso, representavam nesta perspectiva a criação pelo homem de espaços e de zonas delimitadas, susceptíveis de criarem desigualdades artificiais e nessa medida intoleráveis»2[2]. Em suma, segundo esse conceito de igualdade que veio a dar sustentação jurídica ao Estado liberal burguês, a lei deve ser igual para todos, sem distinções de qualquer espécie" (Barbosa, 2001, p. 130).
} 
vivem em situação de desigualdade social e não usufruem de maneira plena deste princípio, visto que ainda existe em nossa sociedade grupos como negros, mulheres, deficientes, indígenas, etc. que vivem em situação de exclusão e vulnerabilidade.

As Políticas de Ação Afirmativa são políticas sociais destinadas a grupos menos favorecidos e historicamente discriminados e/ou minorias, por exemplo: mulheres, negros, indígenas, homossexuais, pessoas com deficiência, etc. Contudo, no Brasil, o debate sobre a legitimidade dessas políticas vem sendo permeado de muita polêmica, passando a fazer parte da pauta de reivindicações dos movimentos sociais junto à sociedade e ao Estado (Assis, 2016, p. 44)

As políticas de ação afirmativa trouxeram legitimidade ao processo de inclusão da população que vive em situação de desigualdade social, principalmente no campo do ensino superior, porém, não podemos deixar de enfatizar que um longo caminho será trilhado, até que a população historicamente discriminada tenha uma reparação histórica no que diz respeito à igualdade de acesso à Universidade.

\begin{abstract}
Como já mencionamos, as políticas de ação afirmativa são destinadas à população historicamente discriminada. Essa população é composta por grupos sociais que não conseguem acessar direitos ditos como universais. Entretanto, para que haja uma reparação histórica desse suposto "esquecimento", é necessário criar políticas sociais públicas e privadas com o objetivo de corrigir esse atraso histórico no campo do ensino superior (Assis, 2016, p. 45).
\end{abstract}

As políticas de ações afirmativas são necessárias para tratar de forma desigual os desiguais, fazendo com que grupos historicamente excluídos, saiam dessa condição. Este é um tema complexo, porém, de extrema relevância, pois trata-se de trazer à luz uma discussão que por muito tempo ficou à margem e até mesmo esquecida, pois a pouca representatividade de pessoas de classes populares e negras nas Universidades eram tidas como normal, tendo em vista a nossa história de um longo período de escravidão e de machismo, em que negros e mulheres não tinham espaço na sociedade. Assim, de acordo com Assis (2016),

(...) compreendemos que a adoção das ações afirmativas como política pública no Brasil é um tema complexo, que está além da questão do acesso das camadas populares a bens e serviços, ou seja, essa medida traz luz a questões históricas inerentes à nossa sociedade, marcas herdadas desde o período colonial, que não foram superadas e que se mantêm enraizadas até os tempos atuais. Contudo, como as desigualdades sociais atingem diretamente o público alvo das ações afirmativas, o efeito dessas políticas tem o caráter de reparação histórica e/ou podem ser utilizadas para amenizar tais marcas e injustiças a esses grupos historicamente discriminados (Assis, 2016, p. 47). 
As políticas de ações afirmativas surgem na perspectiva de respeito às diferenças e também no reconhecimento das desigualdades, de acordo com Heringer, Oliveira e Clapp Salvador (2014),

As ações afirmativas estão voltadas para a garantia e ampliação dos direitos sociais de determinados grupos e se constituem a partir do reconhecimento das condições de desigualdade social em que vivem estes mesmos grupos. Uma proposta baseada no reconhecimento e respeito às diferenças. Neste caso, a proposta de reconhecimento da diferença aparece como estratégia de enfrentamento de uma situação de desigualdade, em busca de uma maior equidade. Portanto, o fundamento da política de reconhecimento é a promoção de uma maior igualdade, a redução das desigualdades e o respeito às diferenças (Heringer; Oliveira; Salvador. 2014, p. 10)

Podemos dizer que as políticas de ações afirmativas têm um caráter de reparação, em que grupos historicamente discriminados e em condição de desigualdade social, conquistam, mesmo que de maneira ainda bastante lenta, direitos que já vêm sendo de gozo dos demais grupos.

No tópico a seguir, faremos alguns apontamos sobre as políticas de ações afirmativas e seus objetivos, levando em consideração seus aspectos no sentido de minimizar as desigualdades sociais existentes de grupos historicamente discriminados.

\subsection{As Políticas de Ações Afirmativas: alguns apontamentos}

As ações afirmativas surgem na perspectiva de eliminar desigualdades históricas, garantindo que grupos minoritários e, até então, marginalizados, tenham igualdade de oportunidades e assim, consigam inserção nos mais diferentes ambientes, como por exemplo, nas universidades, no mercado de trabalho, na política, dentre outros espaços.

A discriminação sobre esses grupos pode se dar por questões raciais, de gênero, étnicas, religiosas, etc. Sendo assim, por meio das políticas de viés afirmativo, se tem a possibilidade de tratar grupos historicamente desiguais de forma inclusiva, de maneira que esses tenham as mesmas oportunidades que os grupos privilegiados.

As políticas de ação afirmativa, "visam beneficiar, de forma diferenciada, grupos discriminados, de modo a permitir que, em médio e longo prazo, possam alcançar condições econômicas, sociais e culturais mais vantajosas, justas e equânimes" (Amaro, 2017, p.141).

Segundo Joaquim Barbosa Gomes (2001), 
As ações afirmativas se definem como políticas públicas (e privadas) voltadas à concretização do princípio constitucional da igualdade material e à neutralização dos efeitos da discriminação racial, de gênero, de idade, de origem nacional e de compleição física. Na sua compreensão, a igualdade deixa de ser simplesmente um princípio jurídico a ser respeitado por todos, e passa a ser um objetivo constitucional a ser alcançado pelo Estado e pela sociedade (Barbosa, 2001, p. 132).

Ainda de acordo com o Ex-ministro Joaquim Barbosa Gomes (2001), as Ações afirmativas, em sua essência nos EUA, se definiam também,

(...) como um mero "encorajamento" por parte do Estado a que as pessoas com poder decisório nas áreas públicas e privadas levassem em consideração, nas suas decisões relativas a temas sensíveis como o acesso à educação e ao mercado de trabalho, fatores até então tidos como formalmente irrelevantes pela grande maioria dos responsáveis políticos e empresariais, quais sejam, a raça, a cor, o sexo e a origem nacional das pessoas. Tal encorajamento tinha por meta, tanto quanto possível, ver concretizado o ideal de que tanto as escolas quanto as empresas refletissem em sua composição a representação de cada grupo na sociedade ou no respectivo mercado de trabalho (Gomes, 2001, p. 134).

Pode-se dizer que, no Brasil, há algumas décadas, se vinha discutindo questões relacionadas à promoção da igualdade racial e social de diferentes grupos, além da diminuição da discriminação em relação a eles. Porém, foi com a Constituição Federal de 1988 que foram criadas políticas que contribuíram para a universalização dos direitos sociais e políticos dos cidadãos oriundos de grupos que viviam em situação de desigualdade.

Para que grupos que vivem historicamente em situação de desigualdade social acessem a determinados bens e serviços e que a discriminação sobre esses grupos diminuam ou, talvez, deixem de existir, faz-se necessário "a adoção das ações afirmativas como política social" (Assis, 2016, p. 47). Ainda de acordo com - referido autor, as políticas de ação afirmativas possuem "um caráter compensatório, pois o histórico de negação de direitos e desigualdades sociais atinge especificamente essa parte da população, a quem se destinam tais políticas" (Assis, 2016, p. 47).

Diversos esforços foram criados, no sentido de "igualar os desiguais", diminuir o preconceito, a discriminação e o racismo, aumentar o acesso de grupos minoritários a espaços, antes, impensáveis de serem acessados, além de sensibilizar a sociedade para o debate em torno deste tema. "Especialmente desde 2000, mediante inúmeros decretos oficiais do governo brasileiro, as políticas afirmativas têm sido implementadas em diferentes setores da sociedade. Atualmente elas já alcançaram áreas como saúde, desenvolvimento agrário, educação, trabalho e emprego, administração pública e relações exteriores" (Amaro, 2017, p. 142). Porém, segundo Amaro (2017), 
(...)a grande "diva" das ações afirmativas brasileiras, de corte racial, indiscutivelmente, é a política de ensino superior e, nesta, as cotas étnico-raciais. O ensino superior, por meio de cotas e do Prouni, tem oportunizado uma verdadeira mudança social no sentido da inclusão para os afrodescendentes. Segundo dados disponibilizados pelo MEC (2010), em 2009, o Programa Universidade para Todos (Prouni) aumentou, em quase 50 mil, o número de alunos negros nas universidades brasileiras. (Amaro, 2017, p. 142).

De acordo com Joaquim Barbosa Gomes (2001) a ação afirmativa é "uma forma jurídica para se superar o isolamento ou a diminuição social a que se acham sujeitas as minorias" (p. 135). Podemos dizer que essas políticas são bastante recentes em nosso país e apesar da inegável desigualdade social, econômica e cultural da população, ainda existe um grupo bastante resistente a elas, por este motivo, essas vêm sendo implementadas de forma bastante lenta e gradual, porém, muito eficaz no Brasil.

Sobre as ações afirmativas, existem grupos que se sentem desconfortáveis em relação a essas políticas, o que faz com que elas "atraiam considerável resistência, sobretudo da parte daqueles que historicamente se beneficiaram da exclusão dos grupos socialmente fragilizados" (Barbosa, 2001, p. 133). Isso reflete um traço marcante de nossa sociedade, principalmente quando falamos dos grupos mais privilegiados.

As políticas de ações afirmativas surgem principalmente como uma resposta de reivindicações dos movimentos sociais, ainda nas décadas de 1980 e 1990, que lutam não apenas por seus direitos, mas também pelo reconhecimento de suas especificidades enquanto grupo social, como nos traz Heringer, Clapp Salvador e Oliveira (2014),

As ações afirmativas, também conhecidas como políticas de reconhecimento ou de discriminação positiva, se distinguem, sobretudo pelo seu caráter especifico, ou seja, são ações voltadas para grupos que vivem em condições históricas de subalternidade, como os negros, mulheres, portadores de deficiência, homossexuais, dentre outros. No caso brasileiro, as políticas afirmativas aparecem como uma resposta às exigências feitas por movimentos sociais pelos direitos coletivos e cultuais (Heringer; Clapp Salvador e Oliveira, 2014, p. 9-10).

A luta dos movimentos sociais contribuiu para que direitos historicamente negados de grupos socialmente excluídos começassem a ser postos e reivindicados no cenário público e assim se tornassem políticas públicas, que beneficiariam tais grupos. De acordo com Heringer, Clapp Salvador e Oliveira (2014), "De uma maneira geral, o movimento negro brasileiro tem sido o responsável pela introdução deste tema no debate público do país" (P. 10). 
Ainda existem muitas críticas em relação a essa temática, principalmente quando falamos das políticas de ações afirmativas que circundam a universidade e o acesso de estudantes negros, segundo Heringer, Clapp Salvador e Oliveira (2014). "Inicialmente (e ainda em parte) o assunto é alvo de muitas críticas e resistências à sua incorporação. As críticas mais comuns destacam que políticas específicas trariam conflito e divisionismo a um país onde as relações raciais seriam harmônicas" (p. 11). Porém, sabe-se que as relações raciais num país como o Brasil, que teve uma história de séculos de escravidão, serão sempre permeados por conflitos, por este motivo, faz-se necessário minimamente equiparar a população negra no que diz respeito a seu acesso no espaço universitário.

A década de 2000 vivenciou o advento da adoção de políticas de ações afirmativas voltadas para a ampliação da presença de estudantes pretos e pardos no ensino superior, num processo que vem se ampliando e consolidando desde então (Heringer, Clapp Salvador e Oliveira, 2014, p. 10 ), assim, é possível afirmar que o Brasil vem passando por diversas mudanças ao longo das últimas décadas, mas ainda há muito o que se discutir sobre o acesso e a permanência de grupos que vivem em situação de vulnerabilidade nas universidades.

De acordo com Amaro (2017), "é papel da universidade e demais instituições de ensino, especialmente as públicas, mobilizar esforços e iniciativas no sentido de promover o direito de populações afrodescendentes e indígenas à educação pública e de qualidade. Mas sabe-se que essa construção não se faz em um clima desprovido de tensões e conflitos" (Amaro, 2017, p. 138).

É comum grupos que vivem marginalizados e em condições de desigualdade social estejam fora dos espaços de privilégio, como o espaço da Universidade, por exemplo. A educação, apesar de ser um direito de todos, ainda é um privilégio de poucos, principalmente daqueles que, durante séculos, tiveram sua condição de cidadãos negada.

Para Amaro (2017),

Séculos de exclusão racial tem enraizado na consciência do brasileiro uma certa naturalização de que "pobres são negros, negros são pobres e que isso é normal, pois sempre foi assim". Romper com essa visão enganosa, por tudo que ela tem de reprodução da discriminação e marginalização social imposta às populações afrodescendentes e indígenas, é fundamental e urgente (Amaro, 2017, p. 138).

No que diz respeitos às ações afirmativas, se faz necessário abrir o diálogo, não somente na direção da política em si, mas, principalmente, nos efeitos que 
ela traz para que haja mudança social, econômica e cultural na trajetória das pessoas que fazem parte de grupos socialmente excluídos, essa discussão precisa extrapolar os muros da Universidade e fazer parte do cotidiano desses grupos. Há uma necessidade urgente de trazer à tona informações a respeito das políticas de reconhecimento, além de ter clareza de que essas políticas precisam atuar "na perspectiva do aprimoramento da cidadania e superação das desigualdades sociais que, histórica e persistentemente, atingem às populações afrodescendentes e indígenas" (Amaro, 2017, p. 138).

Para dar conta das desigualdades sociais existentes em nosso país, principalmente quando falamos da questão do negro em nossa sociedade, as políticas afirmativas (ou "de discriminação positiva", como é chamada em alguns países), surgem para dar luz às diferenças alarmantes de uma parcela da população que é historicamente desfavorecida, ou seja, tratar os diferentes em suas diferenças. Conforme afirma Assis (2016),

As Políticas de Ação Afirmativa são políticas sociais destinadas a grupos menos favorecidos e historicamente discriminados e/ou minorias, por exemplo: mulheres, negros, indígenas, homossexuais, pessoas com deficiência, etc. Contudo, no Brasil, o debate sobre a legitimidade dessas políticas vem sendo permeado de muita polêmica, passando a fazer parte da pauta de reivindicações dos movimentos sociais junto à sociedade e ao Estado (Assis, 2016, p. 44).

No que tange à educação, o propósito de se criar políticas que de fato igualem e democratizem o acesso da população que vive em condições de desigualdade social nas Universidades, é um caminho que já vem sendo trilhado há bastante tempo, porém, de fato, as Leis que permitem que isso ocorra e a forma como estas têm sido implementadas na prática, são bem recentes. Podemos citar aqui, a Lei no $12.711 / 2012^{9}$, que de acordo com Amaro (2017),

(...) em 29 de agosto de 2012, a Presidenta Dilma sancionou a Lei № 12.711/2012, conhecida como Lei das Cotas, que determina que as universidades públicas federais e os institutos técnicos federais reservem, no mínimo, $50 \%$ das vagas para estudantes que tenham cursado todo o ensino médio em escolas da rede pública, com distribuição das vagas entre negros, pardos e indígenas. A aplicação da lei torna ultrapassada a escolha entre "cotas sociais" e "cotas raciais" e demonstra um efetivo e firme propósito do governo em erradicar pobreza, racismo e desigualdade social em um só ato (p. 143).

\footnotetext{
${ }^{9}$ A Lei no 12.711/2012 - Dispõe sobre o ingresso nas universidades federais e nas instituições federais de ensino técnico de nível médio e dá outras providências Art. 10 As instituições federais de educação superior vinculadas ao Ministério da Educação reservarão, em cada concurso seletivo para ingresso nos cursos de graduação, por curso e turno, no mínimo $50 \%$ (cinquenta por cento) de suas vagas para estudantes que tenham cursado integralmente o ensino médio em escolas públicas.
} 
Faz-se necessário ter um debate mais lúcido em torno deste tema (ações afirmativas), principalmente quando falamos de reconhecimento, reconhecer a diferença de grupos que historicamente foram marcados pela opressão, pela marginalidade, pela escravidão, pelo machismo, etc. Para Amaro (2017),

As premissas das ações afirmativas são o reconhecimento de que segmentos historicamente excluídos, por preconceitos arraigados culturalmente, devem receber tratamento diferenciado na promoção da justiça social, como forma de qualitativa e politicamente superar os obstáculos sociais que os espreitam (Amaro, 2017, p. 141).

Reconhecer que toda a desigualdade vivida ao longo dos séculos tem reflexos até os dias atuais e também reconhecer as diferenças de grupos que vivem historicamente no cerne da desigualdade é de extrema importância para que esses grupos tenham igualdade de oportunidades não só nas Universidades, mas no mercado de trabalho e nos mais variados espaços. De acordo com Candau (2004),

\begin{abstract}
Esse reconhecimento é fundamental, mas não basta. Não é suficiente um reconhecimento teórico. Ou formal, expressos em declarações retóricas. Esse reconhecimento tem de ser acompanhados de políticas de valorização, de políticas de acesso a oportunidades. De políticas de acesso ao poder, que são fundamentais para que esses sujeitos sociais tenham uma cidadania plena em nossa sociedade. (Candau, 2004, p. 90)
\end{abstract}

Pensar políticas que minimizem as desigualdades e reconheçam as diferenças e grupos que foram privados, durante muito tempo, de oportunidades, acesso a serviços e tudo mais que lhes fora negado ao longo dos séculos é de extrema importância para criarmos uma sociedade mais justa e igualitária. "É neste contexto que se situam as políticas de ação afirmativa, orientadas a favorecer determinados grupos que tiveram suas oportunidades de acesso e recursos a bens da sociedade negadas ou minimizadas ao longo da história" (Candau, 2004, p. 90).

A política de ação afirmativa teria como um de seus eixos principais promover a igualdade racial no Brasil, pelas cotas, por exemplo, e apesar de recente, sempre houve organizações e movimentos que já discutiam essa pauta e já se mobilizavam contra o racismo e as desigualdades raciais e sociais no país.

Essa história de mobilização, principalmente no período democrático recente, permitiu que, no início do século XXI, o Brasil se reconhecesse como uma sociedade na qual o racismo e as desigualdades raciais estão presentes. $O$ passo seguinte a esse reconhecimento é a determinação em fazer valer os mecanismos políticos, jurídicos e institucionais existentes para que sejam construídas estratégias de 
redução das desigualdades raciais e combate ao racismo em todas as esferas da sociedade brasileira (Heringer, 2004, p. 56).

Enfrentar desigualdades sociais, raciais e o racismo, principalmente no ambiente universitário, não é tarefa fácil, visto que durante décadas a universidade não era um espaço aberto a grupos que vivem em condições desiguais, por isso a importância da democratização do acesso ao ensino superior, não somente acesso, mas também permanência desses grupos. Para promover, de fato, a igualdade nos espaços da universidade, se faz necessário entender as dificuldades desses grupos, não somente para acessar, mas permanecer nele também.

Uma das maneiras que a população que vive em situação de desigualdade social encontrou como estratégia para ingresso nas universidades são os Prévestibulares Comunitários, tratamos dessa iniciativa no item anterior, mas não podemos dissociá-la da discussão a respeito das ações afirmativas, pois são elementos que caminharam juntos na luta pela democratização de acesso e promoção racial e social da população economicamente menos favorecida.

Nas últimas décadas foram criadas uma série de políticas de ação afirmativas que contribuíram não somente para acesso e permanência de grupos como negros, indígenas, LGBTQIA+, dentre outros no ensino superior, mas também em outras áreas como cultura, saúde, trabalho, lazer, esporte, etc.

No campo da educação, as ações concentraram-se na ampliação do acesso e permanência de estudantes negros no ensino superior, principalmente por meio de mecanismos de reserva de vagas, cursos preparatórios e programas de bolsas de estudo e ajuda de custo para estudantes (Heringer, 2004, p.60).

No Rio de janeiro, a primeira experiência de reserva de vagas foi, de acordo com Heringer (2004), em 2003, na Universidade Estadual do Rio de Janeiro (UERJ) e Universidade do Norte Fluminense (UENF), onde ocorreu uma reserva de vagas de $40 \%$ para negros e pardos, o que gerou certo desconforto e até mesmo um debate sobre a legitimidade da política. Não houve muitas informações a respeito da política que esclarecessem a população do que, de fato se tratava, há, até os dias atuais, um sensacionalismo em torno deste tema, o que acaba culminando em uma não aceitação social. Segundo Heringer (2004),

O que ocorria até 2002 é que os candidatos com melhores condições de formação no ensino fundamental e médio, na sua quase totalidade brancos e vindos de escolas particulares, obtinham sempre as melhores notas, principalmente nos cursos mais procurados, e, portanto, ocupavam todas (ou quase todas) as vagas disponíveis. No momento em que se estabeleceram as duas leis prevendo reserva 
de vagas, esses coeficientes passaram a ser diferenciados, pois tanto os alunos vindos da escola pública quanto os alunos negros passaram a concorrer somente entre si, dentro de cada um dos grupos (Heringer, 2004, p. 65).

Outro ponto que ainda é muito debatido seria a respeito da qualidade do ensino desses alunos que entram nas universidades pelas cotas, um grupo ainda bastante privilegiado e preconceituoso de nossa sociedade, questiona como as universidades irão manter suas notas e a qualidade do ensino, recebendo alunos vindos de escolas públicas e de um ensino básico precário. Esse grupo não discute como podemos melhorar a qualidade do ensino da rede pública, mas sim, como barrar essas pessoas de entrarem em um curso de nível superior, eles não querem democratizar o acesso, mas sim acabar com ele.

O que avaliará a qualificação desses alunos para exercer futuramente a profissão será o seu desempenho durante o curso. E aqui cabe rapidamente observar que a verdadeira responsabilidade e missão da universidade é justamente tornar, na medida do possível, igualmente aptos alunos diferenciados nas suas condições de entrada na universidade (Heringer, 2004, p.65).

Devemos levar em conta que há poucas décadas as universidades não estavam preparadas para receber este grupo, seja na sua forma de inserção, seja nos critérios de permanência, por este motivo, é importante também que a cultura da Universidade seja alterada, como uma maneira de acolher esses alunos, isso vai muito além das políticas de ação afirmativa, para Candau (2004),

(...) as políticas de ação afirmativa referentes ao mundo universitário não podem limitar-se a questões ao acesso de sujeitos anteriormente excluídos ou com desiguais oportunidades e possibilidades de ingressar nesse nível de ensino, mas é a chamada cultura da universidade que necessita ser ressignificados a para que as questões multi/interculturais passem a impregnar os diferentes componentes do dia-a-dia da universidade (Candau, 2004, p. 90).

Para tal, devemos pensar que se devem criar mecanismos para que alunos que vivem em situação de desigualdade social ingressem e concluam seus cursos universitários. Por isso, a importância de discutirmos as políticas de ação afirmativa e entender que, não só o Estado tem por obrigação formular políticas que incluam a população menos favorecida nesses espaços, mas que nós também podemos cobrar que essas ações ocorram e que principalmente os espaços universitários estejam preparados para receber estes alunos.

Pensar igualdade social, de gênero e racial em um país como o Brasil não é tarefa fácil, reconhecer que vivemos em uma sociedade machista, racista e classista durante séculos e tentar minimizar os impactos disso na vida da mulher e da população negra e pobre também não é. Se faz necessário criar estratégias 
para melhorar a vida de grupos em situação de desigualdades social, que historicamente possuem suas limitações, consequência de uma questão vergonhosa que é a escravidão, diante disso, devemos pensar que as ações afirmativas não irão resolver todos os problemas enfrentados por grupos excluídos socialmente, mas irão contribuir para derrubar algumas barreiras que impõem limites à eles.

\subsection{As Políticas de Ações Afirmativas no ensino superior - $O$ Papel das Universidades}

A definição de estratégias para alcançar maior igualdade entre grupos historicamente excluídos no Brasil ainda é recente, mas aos poucos vem sendo posta em pauta.

As desigualdades raciais, sociais, educacionais, culturais, de renda e de gênero que vivemos em nossa sociedade ainda são amplas e atingem diretamente sujeitos que ao longo da história não tiveram oportunidades, nem mecanismos para que pudessem minimamente sobreviver perante a exclusão a que eram expostos, por esse motivo a importância de não somente se debater, mas principalmente pôr em prática as políticas de reconhecimento, como as ações afirmativas.

Pensar a igualdade na diferença, principalmente quando o campo de discussão é o acesso e democratização do ensino superior, nos traz uma série de questionamentos, mas para tentar respondê-los, devemos minimamente entender a trajetória dos indivíduos e grupos sociais, além de também analisar suas oportunidades educacionais. Quando falamos de estudantes que vieram de um ensino básico precário e um ensino médio cheio de defasagens, na maior parte dos casos, entendemos que esse terá uma trajetória diferente no que tange ao ingresso e permanência no ensino superior, daí a importância de existirem políticas que deem conta desses grupos.

É inegável que nos últimos anos houve uma abertura das universidades para grupos que historicamente vivem na exclusão - levando em consideração a pouca habilidade delas em receber esses alunos - Parafraseando Barbosa (2015, p. 262), "Quando se considera o acesso ao ensino superior, inegavelmente houve uma abertura acentuada permitindo a entrada de estudantes provenientes de setores anteriormente excluídos desse nível de escolarização".

Mas que tipo de acesso seria esse? É válido salientar que com a abertura das instituições de ensino superior para grupos socialmente desiguais, se faz 
necessário alterar algumas estruturas já impostas nesses espaços. As universidades conseguem fortalecer o vínculo desses alunos com a Instituição? Contribui para o fortalecimento da igualdade de oportunidades educacionais desse aluno? São muitas questões e dificuldades que perpassam na vida acadêmica do aluno pobre na Universidade, assim, de acordo com Barbosa (2015),

As dificuldades de acesso encontradas por jovens pobres e negros podem ser associadas ao funcionamento geral do sistema de ensino brasileiro, extremamente desigual em termos da qualidade oferecida aos alunos provenientes de distintos grupos sociais. Entretanto, quando esses jovens conseguem realizar essa transição decisiva - finalização do ensino médio e entrada no nível terciário -, sua vitória nem sempre se traduz em sucesso escolar; isso ocorre, talvez, porque o Destino socialmente atribuído a eles teime em anular as escolhas feitas, tanto por eles mesmos quanto por ações políticas (Barbosa, 2015, p. 263).

Democratizar o acesso e levar grupos que vivem em condições de desigualdade social para dentro das instituições de ensino superior, vai para além da entrada desse aluno em seu curso, é necessário que sejam criados mecanismos para que ele permaneça e conclua o seu curso. Para tal, políticas que apoiem o estudante são fundamentais, não só com apoio pedagógico, mas também no que diz respeito a uma estrutura econômica, como passagem, alimentação, cotas para xerox, etc., ou seja, uma implementação ou ampliação de uma política de assistência estudantil.

As dificuldades vividas por jovens vindos de situações de desigualdades sociais, vão para além do ingresso, pois o ambiente universitário pode ser muitas vezes alheio a sua realidade e em alguns momentos hostil. Para Barbosa (2015),

As dificuldades encontradas para se informar sobre a vida universitária vão desde a falta de indicações e informações claras sobre a localização física dos prédios com nossos campi sendo desenhados para serem lidos e vividos por aqueles que "naturalmente" aprenderam a lógica dos locais - até a ausência de conhecimento das regras do jogo burocrático (como ter acesso ao alojamento estudantil ou às bolsas para cotistas) ou acadêmico (como fazer trabalhos aceitáveis para os professores, como dialogar com os colegas, como se comportar nos ambientes coletivos) (Barbosa, 2015, p. 263-264).

Pensar no início da vida acadêmica de um jovem que vive em situação de desigualdade social vai para além das políticas que atuam na perspectiva de inclusão dele no ensino superior, como dito anteriormente, se faz necessário criar mecanismos que auxiliem esses jovens a permanecerem no espaço da Universidade. 
A efetividade das políticas de acesso pode ser avaliada pelas suas consequências em termos de garantia da permanência de todos os estudantes até a conclusão dos cursos escolhidos. Ainda que existam fortes indicações de que os fatores culturais sejam mais relevantes para definir o acesso e a permanência no ensino superior, não há dúvidas sobre o impacto do fator econômico (Barbosa, 2015, p. 266).

Outro ponto que dificulta a permanência de grupos que vivem em situação de desigualdade nas Universidades são os horários dos cursos. A maior parte dos alunos de classes populares, senão todos eles, são trabalhadores e já têm horários de trabalho definidos, porém, as faculdades ainda possuem muitos cursos que cumprem uma grade diurna, o que dificulta ainda mais a trajetória universitária desses alunos.

O Programa de Apoio a Planos de Reestruturação e Expansão das Universidades Federais (Reuni) ${ }^{10}$, nesse sentido, contribuiu para que houvesse obrigatoriedade de cursos noturnos, trazendo assim, maior adesão da classe trabalhadora, por parte das universidades, mas, ainda existe, na rede pública, um grande número de cursos diurnos, enquanto nas universidades privadas há um maior número de cursos oferecidos no horário noturno.

Assim, “(...) sabidamente os horários de funcionamento dos cursos têm um efeito de seleção social" (Barbosa, 2015, p. 268), o que contribui para que estudantes oriundos da classe trabalhadora tenham mais dificuldades em permanecer em universidades públicas.

Podemos citar aqui, mais uma vez, um programa criado com a perspectiva de inclusão de alunos oriundos de classes populares nas universidades, que foi o Programa Universidade Para Todos (ProUni) ${ }^{11}$, sendo assim, sua finalidade é,

(...) a concessão de bolsas de estudos para estudantes de baixa renda em curso de graduação e sequenciais em instituições de ensino superior privadas. Foram estabelecidos vários critérios, tanto de desempenho quanto de renda, além da exigência de ter estudado o ensino médio em escola pública. São reservadas vagas também para pessoas com deficiência, pretos, pardos e indígenas (Barbosa, 2015, p. 269).

10 O Reuni é um programa de reestruturação e expansão da educação superior, que tem como objetivo, ampliar o acesso e a permanência na Universidade. O Reuni foi institú́do pelo decreto $n^{\circ}$ 6.096, de 24 de abril de 2007, e é uma das ações que integram o Plano de Desenvolvimento da Educação (PDE). Disponível em http://reuni.mec.gov.br/o-que-e-o-reuni. Acesso em 16 de abril de 2021.

${ }^{11}$ O Programa Universidade para Todos (ProUni) foi criado em 2004, pela Lei o 11.096/2005, e tem como finalidade a concessão de bolsas de estudos integrais e parciais a estudantes de cursos de graduação e de cursos sequenciais de formação específica, em instituições privadas de educação superior. As instituições que aderem ao programa recebem isenção de tributos. http://portal.mec.gov.br/prouni-sp-1364717183/apresentacao>. Acesso em 16 de abril de 2021. 
Em sua gênese, a proposta do ProUni era democratizar o acesso e ser mais um meio de ingresso do estudante pobre na universidade, contribuindo para que os grupos sociais não privilegiados, ingressassem e permanecessem no ensino superior.

Como podemos ver atualmente, mesmo com todos esses esforços para que ocorresse esse ingresso, o ensino superior continua permeado por uma lógica excludente, levando em consideração que tudo gira em torno da tecnologia e dos avanços que ela traz, também devemos levar em consideração, que vivemos em um país de desigualdades extremas, que ainda existem famílias vivendo em situação de miséria, em que não possui água encanada, saneamento básico e moradia digna, além de várias outras problemáticas. Neste caso, como podemos pensar, que o jovem que saiu de uma realidade tão adversa, que viveu toda uma vida no cerne da desigualdade social, oriundo de um ensino público precário, vai conseguir competir com outros jovens, que emergem de uma realidade menos adversa?

A discussão que nos permeia perpassa também pelas oportunidades educacionais. Podemos citar como exemplo a Assistência Estudantil, que apesar de ainda não abarcarem a maioria dos estudantes de classes populares, essas contribuem para a permanência de jovens menos privilegiados na Universidade. A respeito da Assistência Estudantil, Dutra e Santos (2017) nos traz que,

(...) cabe destacar que esse espaço foi conquistado, resultado de intensas lutas sociais, encabeçadas principalmente pelo movimento estudantil, organizado pela União Nacional dos Estudantes (UNE), e pelo Fórum Nacional de Pró-reitores de Assuntos Comunitários e Estudantis (Fonaprace). Essas constituem as principais entidades engajadas na luta por uma AE como direito social e como política pública (Dutra; Santos, 2017, p. 149).

Ainda sobre Assistência Estudantil, as autoras nos trazem que,

Em sua trajetória histórica, a $A E$ (Assistência Estudantil), a partir dos debates e discussões desenvolvidos pelos diferentes grupos/atores sociais envolvidos em sua construção (estudantes, docentes, gestores, profissionais, Estado), nos diferentes contextos sócio-históricos em que tem sido abordada, vai adquirindo diversos sentidos e suscitando diferentes posicionamentos quanto a sua implementação. Desse modo, diferentes projetos de assistência ao estudante no espaço universitário têm sido propostos, os quais podem trazer importantes implicações para as formas adotadas para sua operacionalização nas Instituições de Ensino Superior (Dutra; Santos, 2017, p. 149 [grifos meus]).

Devemos pensar que a base que permeia a finalidade da Assistência Estudantil, é contribuir para que os estudantes pobres tenham recursos de permanência e assim, diminuam o trancamento de matrículas e 
consequentemente a evasão no âmbito da graduação. Para Vasconcelos (2010), ela pode ser vista como um

(...) direito dos estudantes universitários do sistema público de ensino superior, já que visa prover os recursos necessários aos estudantes de baixa condição socioeconômica para que os mesmos possam desenvolver seus estudos com um bom desempenho curricular, minimizando o percentual de abandono, trancamento de matrículas e evasão nos cursos de graduação (Vasconcelos, 2010, p. 600-601).

Para Joaquim Barbosa Gomes (2001), as Políticas de Ações Afirmativas,

Em síntese trata-se de políticas e de mecanismos de inclusão concebidos por entidades públicas, privadas e por órgãos dotados de competência jurisdicional, com vistas à concretização de um objetivo constitucional universalmente reconhecido - o da efetiva igualdade de oportunidades a que todos os seres humanos têm direito (Gomes, 2001, p. 135).

E como dar igualdade de oportunidades para grupos que vivem em meio a tanta desigualdade social? O que podemos refletir é que, mesmo com diversas políticas e incentivos para que esses grupos ingressem no ensino superior, e se tenha criado estratégias de permanência para eles nas universidades, a desigualdade social ainda é um fator decisivo para que alunos oriundos da classe trabalhadora concluam ou não o seu curso de graduação.

\subsection{A inserção das Ex-alunas do Pré-Vestibular Comunitário São Luiz Rei de França nas Universidades por intermédio das Políticas de Ação Afirmativas}

Como afirmado anteriormente, as políticas de ações afirmativas são destinadas a grupos que vivem em situação de desigualdade social. Dentre esses grupos, estão também as mulheres, e este é o grupo no qual realizamos nossa pesquisa, mais especificamente, as ex-alunas do Pré-Vestibular Comunitário São Luiz Rei de França.

Essas que, por sua vez, foram/são moradoras de Costa Barros, e de acordo com as entrevistas realizadas, das sete (7) entrevistadas, três (3) ainda moram em Costa Barros; duas (2) em Orlando (Flórida); e uma (1) em Jacarepaguá, bairro da Zona Oeste do Rio de janeiro. Podemos afirmar também que das sete (7) entrevistadas, seis (6) são oriundas de escola pública e em sua grande maioria ingressaram na universidade por meio de políticas de ações afirmativas.

Ainda sobre as políticas de ações afirmativas, Jardim (2015) nos traz que, 
As políticas de ação afirmativa são direcionadas a diversos segmentos sociais e utilizadas em várias partes do mundo. Apresentadas como estratégia para redução das desigualdades sociais, têm como objetivo o reconhecimento de que grupos socialmente excluídos devem receber tratamento diferenciado para fins de promoção de justiça social. Nos Estados Unidos, país pioneiro, onde tal política é utilizada em larga escala, denomina-se affirmative action ( Jardim, 2015, p. 109)

Aqui no Brasil, temos tido uma experiência bastante exitosa no que diz respeito a essas políticas e em relação aos grupos que elas atendem, como as mulheres, por exemplo. De acordo com Jardim (2015, p. 109), "no que diz respeito especificamente à questão das relações de gênero, são medidas que visam à aplicação das leis de igualdade, pois objetivam o desenvolvimento de programas que possam garantir às mulheres avanços concretos".

Ainda de acordo com a autora, "a desigualdade de oportunidades é um dos principais argumentos que justificam a implementação de ações afirmativas no Brasil" (Jardim, 2015, p. 114), assim, precisa caminhar ainda mais para que de fato grupos que vivem em situação de desigualdade e excluídos tenham igualdade de oportunidades.

No caso das ex-alunas do PVCSLRF, conforme dito anteriormente, em sua grande maioria vieram do ensino básico público, o que nos faz pensar que esse ensino, na maioria das vezes, além de ter uma baixa qualidade, é excludente e deficitário.

O fato de terem chegado no espaço universitário e terem encontrado no caminho a possibilidade de entrada pelas políticas de ações afirmativas foi de grande importância, visto que normalmente o ingresso na Universidade não seria uma opção para essas mulheres, levando em consideração que a maioria delas tinham como meta inicial, no momento em que saíam do ensino médio, ingressarem no mercado de trabalho e contribuíssem para a subsistência de seu grupo familiar, ou seja, a entrada na Universidade contribuiu para uma mudança considerável na vida dessas mulheres, tornando suas trajetórias diferentes do que já estava previamente estabelecido.

O ensino superior brasileiro tem um caráter excludente, desde sua forma de ingresso, até a de permanência, dentro do espaço da universidade. Essa foi pensada única e exclusivamente para atender a uma classe dominante, que, em via de regra, se prepara toda uma vida escolar para que o estudante chegue até a universidade, diferente do que ocorre com os alunos oriundos da classe trabalhadora, que além de virem de um ensino precário, quando chegam à fase adulta, possuem outros objetivos e poucas oportunidades. 
Ratificando o caráter excludente do Ensino Superior brasileiro, apontou-se para o fato de que, no Brasil, enquanto o ensino básico de qualidade é privado, as melhores instituições de Ensino Superior são públicas. Tal situação nega aos estudantes das classes populares, oriundos da escola básica pública, condições adequadas para competir, em pé de igualdade, com as classes média e alta por um lugar na educação superior pública de qualidade (Jardim, 2015, p. 114)

Ainda de acordo com a autora, pode-se destacar que um dos objetivos centrais das ações afirmativas é colocar em evidência questões como desigualdade de gênero, étnicas, entre outras. No caso do Brasil, tendo em vista a prevalência da questão de classe, no campo das ações afirmativas, torna-se esta também um importante indicador (Jardim, 2015, p. 115).

Para que de fato haja a inclusão das mulheres no espaço universitário, tratamos aqui especificamente de mulheres oriundas da favela e ex-alunas do PVCSLRF, deve-se pensar em todo o histórico de exclusão e marginalidade em que elas viviam inseridas. Incluir essas mulheres no espaço universitário, depois de décadas de subalternidade, é de extrema importância para o combate às desigualdades sociais.

\begin{abstract}
De fato, o acesso de estudantes pertencentes a grupos marginalizados e subrepresentados às Universidades Brasileiras e ao conhecimento socialmente valorizado é incrementado pela adoção de políticas de ação afirmativa. O enfrentamento das desigualdades sociais no Brasil torna-se urgente, bem como a viabilidade de políticas que possam concorrer para a instituição de uma sociedade sem qualquer tipo de discriminação (Jardim, 2015, p. 115).
\end{abstract}

Falar das desigualdades sociais que acompanham o cotidiano dessas mulheres, torna-se em diversos aspectos importante e para além disso, discutir as políticas de ação afirmativas que contribuem para que haja uma maior promoção de igualdade de oportunidades no campo da educação é ainda mais importante.

Vimos que nas últimas décadas houve uma mudança considerável do perfil dos estudantes no ensino superior, mas isso não quer dizer que esse processo não tenha sido conflituoso, para Jardim (2015, p. 124), "as políticas de ação afirmativa nas Universidades provocam um intenso debate envolvendo o meio acadêmico, o Judiciário, a mídia, os movimentos sociais e o senso comum".

Todos têm algo a dizer sobre essa temática, sendo opinião contrária ou a favor. Ainda sobre isso, Heringer (2018, p. 9) nos traz que "Inicialmente (e ainda em parte) o assunto é alvo de muitas críticas e resistências à sua incorporação. As críticas mais comuns destacam que políticas específicas trariam conflito e divisionismo a um país onde as relações raciais seriam harmônicas". 
Mesmo em um ambiente de muitos conflitos e discordâncias, as políticas de ação afirmativas tem tido resultados muito positivos para a população que vive em situação de desigualdade social.

As políticas de ação afirmativas estão intimamente ligadas ao sucesso acadêmico dessas ex-alunas do PVCSLRF, conquistar uma vaga no ensino superior foi algo extremamente positivo para elas, como analisaremos posteriormente, que em sua maioria foram as primeiras pessoas de suas famílias a pisarem em uma Universidade e assim, houve um esforço grande por parte delas em permanecerem nesses espaços e concluírem seus cursos.

Não podemos deixar de mencionar, que o próprio acesso à Universidade já é uma mudança no status das ex-alunas do PVCSLRF, visto que trata-se de mulheres pobres, que vêm de um histórico familiar de marginalidade e exclusão, e esse acesso configura algumas mudanças, não somente em suas vidas, mas em seus espaços de convivência.

Assim, as políticas de ação afirmativa "Embora seja uma política de um Estado neoliberal, em uma sociedade capitalista, é inegável que a política de cotas vem promovendo maior acesso da população pobre, negra e indígena à educação superior" (Cordeiro, 2013, p. 301).

Então, por meio dessas políticas e da possibilidade de ingresso nas Universidades, essas mulheres vêm construindo um futuro diferente das mulheres de suas gerações anteriores, o que já traz uma mobilidade geracional, de que falaremos melhor adiante.

Não podemos deixar de lembrar, que é dever do estado promover ações de igualdade de oportunidades, combate à discriminação, acesso a bens e serviços, etc. para a população que vive em situação de desigualdade social. Nesta perspectiva, as ações afirmativas de acesso à educação superior constituem um passo importante para retirar da pobreza e dos baixos níveis de escolarização grande parte da sociedade brasileira, possibilitando ao país um desenvolvimento baseado na inclusão social (Cordeiro, 2013, p. 302).

As políticas de ações afirmativas contribuíram não somente para o ingresso e permanência desse grupo nas universidades, mas também para transformações posteriores na vida dessas mulheres. Sair da condição de desigualdade social, pobreza, alcançar outros patamares intelectuais, melhores condições de trabalho e salário, mudanças em suas relações sociais e familiares e assim por diante.

Para essas ex-alunas do PVCSLRF, a educação superior foi um fator significativo de mudanças em suas trajetórias, além do acesso à educação superior, elas puderam ter não apenas conhecimento, mas acesso à informação, 
cultura, desenvolvimento intelectual e pessoal, visto que este é restrito a pessoas vindas das classes populares.

Neste sentido, vimos a importância das políticas de ação afirmativas como instrumento de ingresso de grupos que vivem em situação de desigualdade social nas Universidades, além de contribuírem para a permanência desses grupos no espaço universitário.

Como vimos neste capitulo, as Políticas de Ações Afirmativas foram de extrema importância para a inserção de alunos de classes populares nas Universidades. No capitulo a seguir, faremos a análise e mostraremos os resultados da nossa pesquisa que obtivemos por meio das entrevistas com as exalunas do PVCSLRF. 


\section{5. \\ A importância do Pré-Vestibular Comunitário São Luiz Rei de França na trajetória de vida Pós-Universidade - A perspectiva das ex-alunas}

Os pré-vestibulares populares (PVPs) são organizações comunitárias que atuam diretamente na formação das classes populares para que possam acessar aos cursos de ensino superior. Além disso, os PVPs proporcionam um espaço para o debate de questões sociais, raciais, gênero, etc. com o objetivo de formar cidadãos críticos e conscientes da realidade social.

O trabalho desenvolvido pelo PVCSLRF não foi diferente e atuou tanto no campo da educação formal, quanto no campo da formação crítica. Esta dinâmica pode ser percebida a partir das narrativas das ex-alunas entrevistadas nesta pesquisa.

As entrevistadas apontam a importância do CPVC na trajetória das exalunas, contam a história do curso e sua importância, não só na vida dessas mulheres, mas na história da Paróquia na qual ele esteve alocado. Desta forma, o presente capítulo trata os resultados desta pesquisa, conforme veremos a seguir.

O item 5.1, "Perfil das Ex-Alunas do Pré-Vestibular Comunitário São Luiz Rei de França", abordaremos sobre as alunas que foram do curso entre os anos de 2005 a 2010, período em que o CPVC esteve ativo. Para a obtenção desses dados, conforme anteriormente explicitado, aplicou-se um questionário com perguntas abertas e fechadas, para o qual se obteve um total de sete (7) entrevistas.

Os dados correspondem a informações referentes ao perfil propriamente dito das entrevistadas: nome, sexo, estado civil, raça, etc., além de mais três blocos de perguntas referentes ao Pré-Vestibular Comunitário São Luiz Rei de França, políticas de ação afirmativas e sobre a trajetória pessoal, profissional e acadêmica das entrevistadas.

Cabe ressaltar que devido ao período de pandemia do novo coronavírus, todas as entrevistas foram realizadas de forma remota pela plataforma Google Meet, porém, sem nenhum prejuízo à pesquisa. 
No item 5.2, analisa-se o Pré-Vestibular Comunitário São Luiz Rei de França e sua importância na perspectiva de suas ex-alunas. A intenção é identificar a percepção das ex-alunas sobre o PVCSLRF, além de, por meio da fala das participantes, resgatar um pouco da história do curso e sua importância.

No item 5.3, trataremos sobre as políticas de ações afirmativas, sua importância para as ex-alunas, suas opiniões a respeito dessas políticas, se outras pessoas de suas famílias já haviam ingressado no ensino superior anteriormente, se teve acesso à Assistência estudantil, etc. Almeja-se compreender como se deu o ingresso dessas mulheres no ensino superior e como foi o processo de permanência já dentro da universidade.

No item 5.4, apresentaremos um pouco sobre a trajetória pessoal, profissional e acadêmica das ex-alunas do PVCSLRF. Analisaremos também como era a vida dessas mulheres antes, durante e depois do curso de nível superior, qual o impacto de um diploma universitário na vida dessas ex-alunas, e por fim, quais mudanças ocorreram em suas trajetórias, após a conclusão do curso de nível superior.

Levando-se em conta a percepção das ex-alunas quanto ao PVCSLRF, as políticas de ações afirmativas e suas trajetórias pós-Universidade, finalizamos nossa pesquisa com os dados que se seguem.

\section{1.}

\section{Perfil das Ex-Alunas do Pré-Vestibular Comunitário São Luiz Rei de França}

As entrevistas foram realizadas com as ex-alunas do Pré-Vestibular Comunitário São Luiz Rei de França, no período de outubro a novembro de 2020, todas as sete (7) entrevistadas participaram do CPVC no período correspondente aos anos de 2005 a 2010.

Considerando que nesta pesquisa aderimos ao recorte de gênero, identificamos dez (10) ex-alunas do PVCSLRF, dessas, sete (7) nos retornaram e se dispuseram a participar da pesquisa.

Abaixo segue gráfico que corresponde ao perfil das ex-alunas: 
Tabela 1 - Dados das entrevistadas - Infográfico. Fonte: elaboração própria.

\begin{tabular}{|c|c|c|c|c|c|c|c|c|}
\hline Nome & Idade & Raça & $\begin{array}{l}\text { Estado } \\
\text { Civil }\end{array}$ & Unwersidade & $\begin{array}{l}\text { Forma de } \\
\text { ingresso }\end{array}$ & $\begin{array}{l}\text { Ano de } \\
\text { PVCSLRF }\end{array}$ & $\begin{array}{l}\text { Ano de ingresso } \\
\text { na Unwersidade }\end{array}$ & Curso \\
\hline I & 42 & Branca & Divorciada & Gama Filho & Prouni & 2006 & 2008 & Psicologia \\
\hline MW & 31 & Branca & Casada & UERU & Cotas & 2007 & 2008 & Psicologia \\
\hline SM & 32 & Parda & Casada & Estácio & ProUni & 2006 & 2007 & $\begin{array}{c}\text { Propaganda e } \\
\text { Marketing }\end{array}$ \\
\hline$M C$ & 38 & Parda & Casada & Unicarioca & Prouni & 2006 & 2009 & Administraçầo \\
\hline $\begin{array}{ll}T \\
\end{array}$ & 31 & Branca & Casada & UFRS & $\begin{array}{c}\text { Ampla } \\
\text { Concorréncia }\end{array}$ & 2006 & 2009 & Administraçăo \\
\hline $\mathrm{n}$ & 34 & Parda & Casada & Unicarioca & Proun & 2006 & 2008 & Administraçăo \\
\hline
\end{tabular}

Para melhor entendermos o perfil dessas ex-alunas, fizemos alguns gráficos, por meio dos quais podemos ilustrar melhor as condições sociais e acadêmicas desse grupo.

Como veremos no gráfico 2, a idade das ex-alunas atualmente:

\section{Gráfico 1 - Idade das ex-alunas}

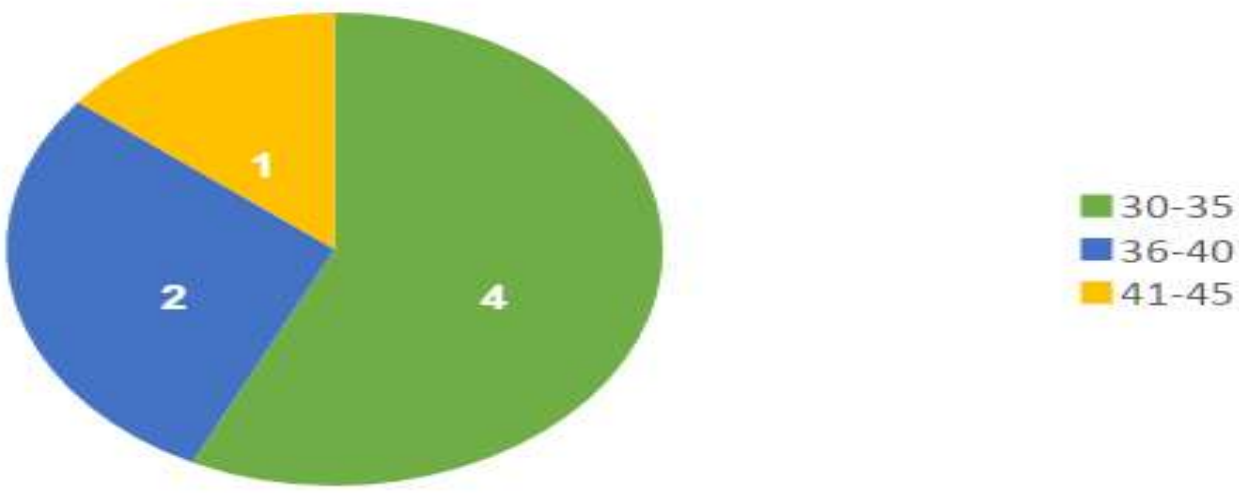

Fonte: Produzido pela autora, dados coletados durante as entrevistas de outubro e novembro de 2020.

Pudemos avaliar que no ano de 2020, ano em que a pesquisa foi aplicada, quatro (4) das entrevistadas tinham entre 30 e 35 anos, duas (2) estavam na faixa 
etária entre 36 e 40 anos, enquanto uma (1) delas estavam com idade entre 41 e 45 anos.

Conforme apresentado no gráfico 2 , em relação ao estado civil, nota-se que seis (6) dessas mulheres estavam casadas, enquanto apenas uma (1) estava divorciada.

\section{Gráfico 2 - Estado civil declarados pelas ex-alunas}

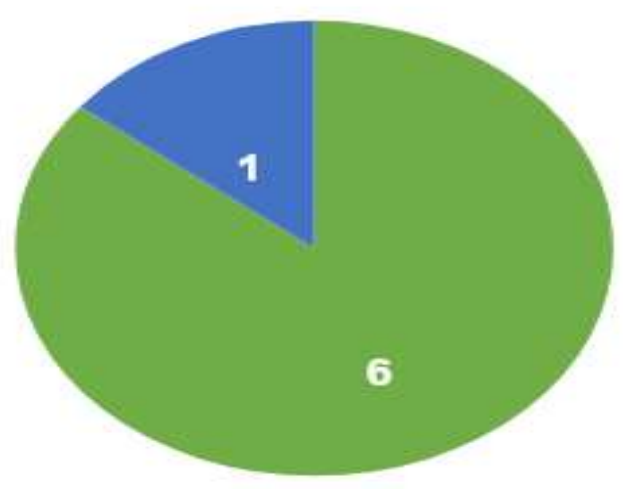

Casada

- Divorciada Solteira

Fonte: Produzido pela autora, dados de outubro e novembro de 2020.

Podemos analisar também que no grupo de entrevistadas, conforme gráfico 3, quatro (4) das entrevistadas se autodeclaram pardas, enquanto três (3) de autodeclaram brancas.

\section{Gráfico 3 - Raça autodeclarada}

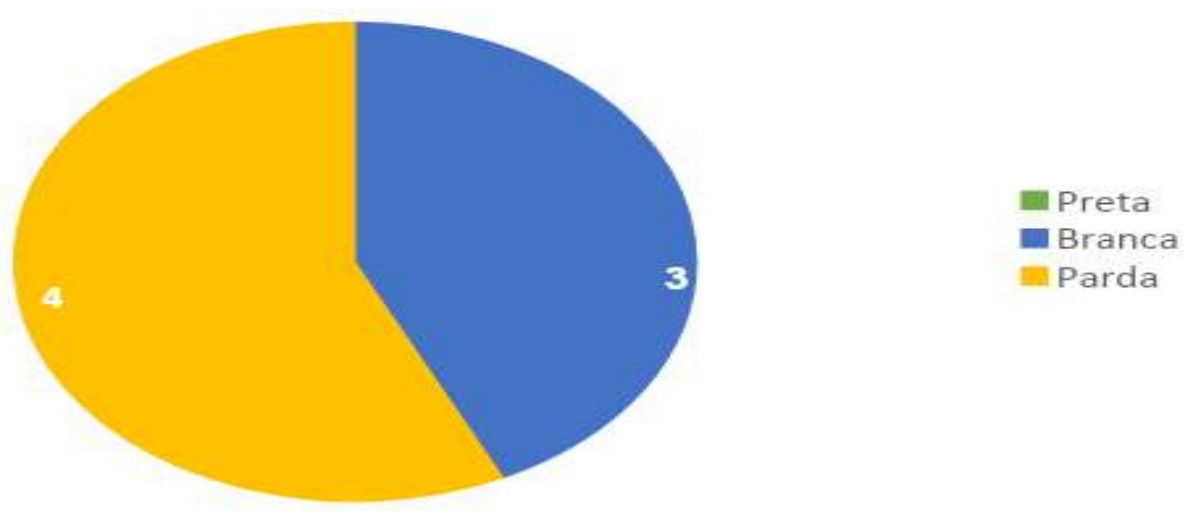

Fonte: Produzido pela autora, dados de outubro e novembro de 2020. 
Conforme gráfico 4, das ex-alunas entrevistadas uma (1) delas entrou na Universidade no ano de 2007, quatro (4) no ano de 2008 e duas (2) no ano de 2009. Não podemos deixar de destacar que, no início dos anos 2000 , houve um grande investimento no que diz respeito às políticas de educação, de expansão do ensino superior e das políticas de ações afirmativas. Esse movimento iniciouse no governo Fernando Henrique Cardoso (1995 - 2002), e ganhou continuidade no governo Luiz Inácio Lula da Silva $(2003-2010) .{ }^{12}$

\section{Gráfico 4 - Ano em que ingressaram na Universidade}

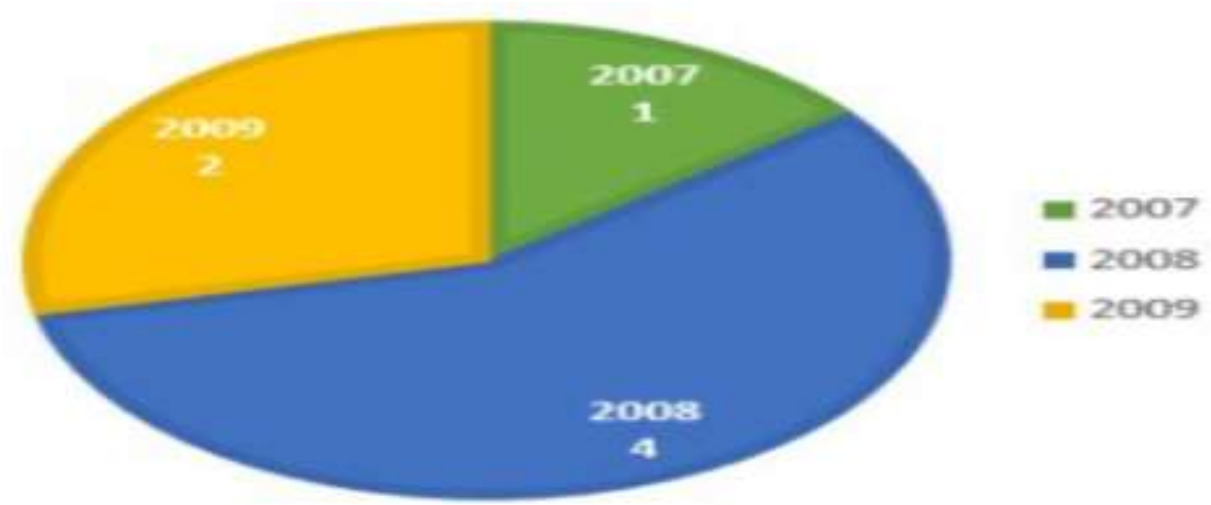

Fonte: Produzido pela autora, dados de outubro e novembro de 2020.

Nos dados relativos ao curso que as entrevistadas concluíram, podemos dizer que do total das entrevistadas, uma (1) cursou letras, uma (1) Propaganda e Marketing, duas (2) Psicologia, enquanto três (3) cursaram Administração, conforme gráfico 5 .

\footnotetext{
12 "No Governo Lula (2003-2010) assistiu-se ao aprofundamento da Reforma do Ensino Superior, iniciada no Governo FHC. Um exemplo a citar é a introdução do modelo de educação superior à distância, que passa por um processo de franca expansão, após a proposta de reforma universitária. É no governo de FHC e Lula que a reforma chega ao seu apogeu, sendo materializada pela Lei de Diretrizes e Bases da Educação (LBD). As alterações no Ensino Superior, indicadas na LDB, foram as propostas de reforma universitária do governo FHC, materializadas no governo Lula. Dentre as medidas estão: exame nacional de curso, mestrado profissionalizante, substituições dos currículos mínimos por diretrizes curriculares, cursos sequenciais, ensino à distância em todos os níveis, seguindo recomendações dos organismos internacionais, no sentido de diversificação e massificação do ensino e de reconfiguração das profissões" (Jardim, 2015, p. 49).
} 


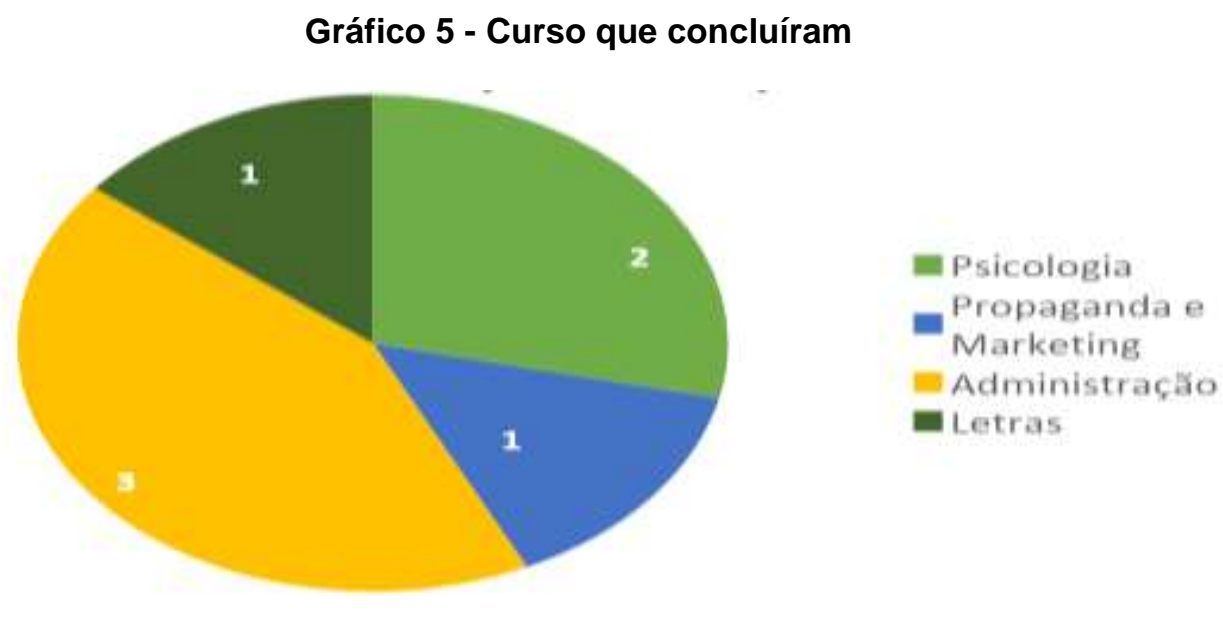

Fonte: Produzido pela autora, dados de outubro e novembro de 2020.

Em relação a inserção das ex-alunas na Universidade, das sete (7) entrevistadas, apenas uma (1) entrou por ampla concorrência, enquanto as outras seis (6) entraram por intermédio de políticas de ações afirmativas. O fato da maioria das entrevistadas terem acesso à Universidade via Políticas de ações afirmativas, nos faz reafirmar a importância das políticas de reconhecimento como mecanismo eficaz para o ingresso de grupos desiguais às Universidades e consequentemente como um instrumento de democratização do ensino superior.

O gráfico 6 nos mostra como se deu a inserção dessas ex-alunas no espaço universitário, o que nos faz entender a importância das políticas de ação afirmativas na vida das mulheres entrevistadas. As desigualdades sociais presentes em nossa sociedade contribuem para que as mulheres vindas da classe trabalhadora tenham mais dificuldades em acessar determinados espaços, como por exemplo, o espaço universitário, por este motivo a importância de políticas de reconhecimento, principalmente como forma de igualar as condições de ingresso de grupos menos favorecidos.

Não podemos deixar de citar que as políticas de reconhecimento visa a reparação de grupos específicos, que segundo Jardim (2015, p. 128) "sofreram ciclos contínuos de exclusão social" e que essas mulheres pobres e vindas de favelas fazem parte desses grupos. 


\section{Gráfico 6 - Formas de ingresso na Universidade}

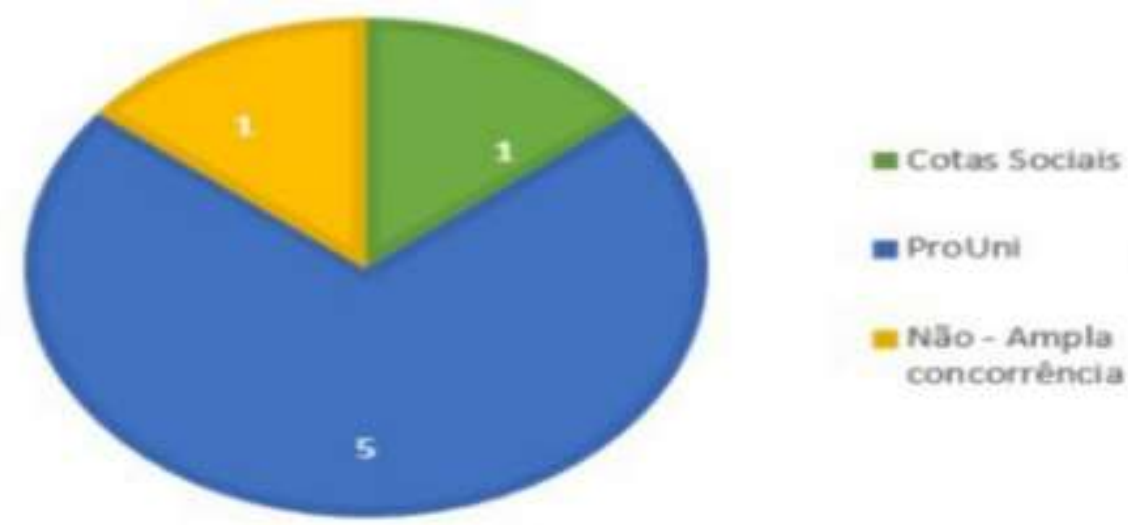

Fonte: Produzido pela autora, dados de outubro e novembro de 2020.

Outro ponto que questionamos foi sobre o fato das ex-alunas trabalharem ou não durante as aulas do CPVC. Das sete (7) entrevistadas, apenas duas (2) trabalhavam enquanto participavam das aulas, o que nos faz atentar para o fato de que esse grupo teve mais oportunidades de se dedicarem às aulas, visto que não tinham uma rotina de estarem inseridas no mercado de trabalho naquele momento.

O que podemos dizer a respeito do perfil das ex-alunas é que ingressaram na universidade no mesmo período (entre os anos de 2007 e 2009) e com uma faixa etária bem parecida. Em sua maioria, esse ingresso se deu pelas políticas de ação afirmativa e todas utilizaram o CPVC como instrumento para acessar à Universidade.

É possível afirmar, que todas estavam cursando sua primeira graduação, em sua grande maioria eram casadas, enquanto apenas uma (1) estava divorciada. Outro ponto que podemos destacar é o fato de que todas as mulheres moravam em Costa Barros no período de ingresso e permanência na Universidade e que vieram de famílias que estavam em condição de desigualdade social, pobreza e exclusão.

\subsection{O Pré-Vestibular Comunitário São Luiz Rei de França - A sua importância na perspectiva de suas ex-alunas}

Conforme abordado nos capítulos anteriores, os CPVC's surgiram numa perspectiva de preparar estudantes em condições de desigualdade social para ingresso nas Universidades, permitindo assim, que esse grupo que vive em 
condições de exclusão, no que diz respeito ao acesso à educação, conquiste outros níveis de escolaridade.

Pode-se afirmar que o PVCSLRF foi de extrema importância para as exalunas, pois além de tudo o que já foi afirmado anteriormente, elas não teriam condições de pagar por um curso privado. Podemos dizer que o Estado investe o mínimo na área da educação, fazendo com que essas mulheres, vindas do ensino público, acabem tendo suas chances reduzidas no momento do vestibular em relação aos vestibulandos que vêm de outras camadas sociais.

Diante disso, afirmamos que "nesta ótica, o Ensino Superior permanece elitizado e excludente, principalmente nos cursos mais concorridos e de maior status social, os quais a entrada, via vestibular, pressupõe o custo de um ensino médio de qualidade, muitas vezes, somado a uma preparação via curso prévestibular" (Jardim, 2015, p. 48).

Esta pesquisa teve como um de seus eixos estudar sobre a importância do PVCSLRF na perspectiva das ex-alunas. Para tanto, analisou-se as respostas obtidas em relação à seguinte questão: Você considera que o Pré-Vestibular Comunitário São Luiz Rei de França foi importante para sua inserção na Universidade? De que forma ele foi importante?

Sobre a importância do PVCSLRF, a entrevistada MW nos traz o seguinte depoimento:

Eu acredito que sim! Com certeza! A gente não tinha tanto acesso até a informação né, naquela época como se tem hoje, celular, smartphone, onde a gente pode verificar várias informações sobre provas, inscrições, onde está aberto determinadas vagas e naquela época o pré-vestibular se tornou um meio de informação também né, porque a falta de informação, tira o nosso acesso às coisas assim. E os familiares que nunca tiveram acesso a isso, não tinham noção de como isso funcionava, então, dentro do pré-vestibular eu encontrei várias pessoas que me ajudaram a seguir esse caminho, do vestibular de todo esse processo da prova, não só apenas estudar, mas mostrar "os caminhos das pedras", né? Então, eu acho que foi fundamental.

Ainda sobre o questionamento acima, a entrevistada MC disserta a respeito:

Sim, bastante importante. Porque a gente não tinha acesso à internet, assim como a gente tem agora, então, foi importante na época, os professores dando dicas, apoiando, a gente indo nas Universidades conhecer, saber sobre o ProUni, porque também eu não conhecia na época, então, foi de super relevância pra minha formação.

Como podemos observar na fala das entrevistadas, o CPVC contribuiu não apenas para o ingresso na Universidade, mas foi instrumento de informação e 
inclusão para essas ex-alunas, que no período não possuía acesso à tecnologia e informação, como por exemplo, internet.

Ainda sobre o PVCSLRF, no que diz respeito à importância deste tipo de curso dentro de uma favela e para o ingresso das mulheres moradoras desses espaços, as entrevistadas nos trazem tais informações:

Porque quase não se tem acesso, o único meio que se tem acesso é a escola, mas nem sempre alcança, como deveria alcançar, até porque é um grupo muito grande, com necessidades específicas dentro da escola e o pré-vestibular vai afunilando um pouquinho, até quem tem o desejo, quem tem a vontade de entrar num nível superior, ele afunila e ajuda as pessoas a ter um objetivo mais claro e conseguir isso (Entrevistada MW).

Ainda sobre a importância desses CPVC's dentro das favelas de Costa Barros, as entrevistadas afirmam:

Sim, Sim porque a população que vive na favela, a gente sabe que é desprivilegiada em todos os aspectos e eu acredito que esse pré-vestibular comunitário possibilita né, a essa classe, não só de mulheres, mas também a essa classe social, de ter a oportunidade, a chance de ingressar no ensino superior e eu acredito que seja importante sim, por esses aspectos de inclusão né! (Entrevistada T).

Eu acho que sim, com certeza. Porque, por exemplo, ali na nossa área, aonde a gente mora, não tinha nada, não tinha nenhuma ação que ajudasse, quando criaram o pré-vestibular, com certeza, eu era a primeira, tipo, quero estar lá, eu quero poder participar, eu acho que incentivou, ajudou, é... antes de lá, eu já fazia lá na Pavuna, só que tipo eu e $D$, tinha uma companhia, lá embaixo a gente ia caminhando até um posto de gasolina que tem indo ali para Grande Rio, saia do metrô, a gente se encontrava depois do trabalho, ia até o metrô e depois ia até lá em São João, lá embaixo, perto do Grande Rio, perto do posto de gasolina e subia estudava, voltava, então, pra ficar sozinha, indo e voltando à noite, ali não dava, era meio perigoso, então falei: "não", então, eu tive que parar. Quando começou ali na igreja, não pensei duas vezes, era a chance de eu continuar estudando, pra tentar uma chance né, de poder estudar (Entrevistada VB).

Desta forma, pode-se, então, constatar a importância que o PVCSLRF teve não somente na vida dessas mulheres, mas também o impacto positivo que teve no bairro, como as mesmas expuseram. Trouxe também outras formas de organização, como por exemplo, captação de novos alunos e professores, estabelecimentos de novas redes, além da própria parceria com o pároco responsável pela paróquia na época.

Os Pré-Vestibulares Comunitários trouxeram novos atores sociais para espaços de participação social e esses novos atores passam a ter contato com diversas questões inerentes à realidade das comunidades, o que faz do PVC um espaço de reflexão dos problemas das comunidades e de busca de soluções para atender às demandas que são apresentadas (Assis, 2016, p. 64) 
Ter um CPVC dentro de um bairro pobre, em que muitas pessoas vivem em condições de exclusão e desigualdade social foi importante não só pela articulação com os atores locais, mas também pelo período em que ele se manteve ativo (2005 a 2010), pois foi um período de efervescência das políticas educacionais, como dito anteriormente.

Podemos analisar também que das sete (7) entrevistadas, cinco (5) viveram sua primeira experiência em um CPVC, enquanto outras duas (2) já haviam participado de alguma experiência anterior.

Não, eu fiz um tempo na EDUCAFRO também, (...) e fiz um tempo pré-vestibular na UERJ (Entrevistada VL).

Minha primeira experiência? A Primeira experiência que você tá falando? Não, era o Pré-vestibular lá em São João de Meriti, era numa igreja, esse foi o primeiro que eu fiz, eu ia com a minha irmã e a gente ia pra lá. Era todo dia, de segunda a sexta, à noite, tinha bastante matéria também, bastante professor e foi lá que ela conseguiu passar no vestibular e ganhar a bolsa dela (Entrevistada VB).

Para as ex-alunas que não estavam ingressando pela primeira vez em um CPVC, aquela oportunidade tornava-se uma nova chance de prestar vestibular/ENEM e conquistar uma vaga na universidade. A partir das experiências de participação nos CPVC's, essas mulheres classificaram como positiva suas respectivas passagens nesses cursos e puderam avaliar a importância dos mesmos em suas trajetórias.

\subsection{Políticas de Ação Afirmativas na Perspectiva das Ex-Alunas}

Como afirmado anteriormente, as políticas de ação afirmativa se apresentam como estratégias para redução das desigualdades sociais, elas abarcam minorias políticas e culturais, tais como mulheres, deficientes físicos, alunos de escola pública, índios, entre outros segmentos sociais (Jardim, 2015, p. 109).

De acordo com Joaquim Barbosa Gomes (2001)

Inicialmente, as Ações Afirmativas se definiam como um mero "encorajamento" por parte do Estado a que as pessoas com poder decisório nas áreas pública e privada levassem em consideração, nas suas decisões relativas a temas sensíveis como o acesso à educação e ao mercado de trabalho, fatores até então tidos como formalmente irrelevantes pela grande maioria dos responsáveis políticos e empresariais, quais sejam, a raça, a cor, o sexo e a origem nacional das pessoas. Tal encorajamento tinha por meta, tanto quanto possível, ver concretizado o ideal de que tanto as escolas quanto as empresas refletissem em sua composição a 
representação de cada grupo na sociedade ou no respectivo mercado de trabalho (p. 136).

Dito isso, faremos uma análise de como o grupo pesquisado, que são as exalunas do PVCSLRF, e de como essas acessaram à Universidade e se as políticas de ação afirmativa contribuíram ou não para esse acesso.

Começaremos afirmando que das sete (7) entrevistadas, seis

ingressaram pelas políticas de ação afirmativa, cinco (5) foram pelo ProUni, uma (1) pelas cotas sociais e apenas uma (1) entrou por ampla concorrência. O que nos faz reafirmar a importância dessas políticas na vida dos grupos que vivem em condições de desigualdade social. Grupos que antes viviam discriminados e excluídos socialmente encontram nessas políticas a possibilidade de transformar suas trajetórias e alterar sua condição que antes era de vulnerabilidade. Segundo Joaquim Barbosa Gomes (2001),

\begin{abstract}
Atualmente, as ações afirmativas podem ser definidas como um conjunto de políticas públicas e privadas de caráter compulsório, facultativo ou voluntário, concebidas com vistas ao combate à discriminação racial, de gênero, por deficiência física e de origem nacional, bem como para corrigir ou mitigar os efeitos presentes da discriminação praticada no passado, tendo por objetivo a concretização do ideal de efetiva igualdade de acesso a bens fundamentais como a educação e o emprego. Diferentemente das políticas governamentais antidiscriminatórias baseadas em leis de conteúdo meramente proibitivo, que se singularizam por oferecerem às respectivas vítimas tão somente instrumentos jurídicos de caráter reparatório e de intervenção ex post facto, as ações afirmativas têm natureza multifacetária, e visam a evitar que a discriminação se verifique nas formas usualmente conhecidas - isto é, formalmente, por meio de normas de aplicação geral ou específica, ou através de mecanismos informais, difusos, estruturais, enraizados nas práticas culturais e no imaginário coletivo. Em síntese, trata-se de políticas e de mecanismos de inclusão concebidos por entidades públicas, privadas e por órgãos dotados de competência jurisdicional, com vistas à concretização de um objetivo constitucional universalmente reconhecido - 0 da efetiva igualdade de oportunidades a que todos os seres humanos têm direito (Gomes, 2001, p 137).
\end{abstract}

Sobre a perspectiva das ex-alunas em relação às políticas de ação afirmativas, pode-se destacar alguns apontamentos feitos pelas ex-alunas a respeito da importância dessas políticas.

Acho importante, porque fez toda a diferença pra mim, porque senão, eu não teria como arcar com os custos, já que eu não consegui a nota para passar em uma Universidade pública. E ainda assim, mesmo obtendo a bolsa, a gente precisava também do material, aí, eu contei com a ajuda da família. Passagem, alimentação e material de estudo.

São políticas necessárias, porque já que a gente não tem uma qualidade no ensino de base, em que ajude as pessoas a conseguirem entrar na faculdade pública, que deveria ser, já que você não pode arcar com uma faculdade particular, deveria ser um acesso desde o ensino básico até a Universidade, já que não conseguimos assim dessa forma, essas políticas de inserção via bolsas, via outros projetos é o que faz com que aquela pessoa com toda a dificuldade ainda assim consiga o 
ingresso no ensino superior, o que não garante a permanência, que isso daí é um outro patamar (Entrevistada I).

Eu acho que elas ajudam a minimizar bastante essa desigualdade social, porque se a gente for no sistema, do jeito que ele está sendo feito né, há anos, a gente sabe que muita gente não vai conseguir de fato concorrer de uma forma leal né, por esse sistema que não foi feito pra pobre, nem pra mulher, nem pra negro. Eles ajudam, no caso, as cotas, as ações afirmativas, ajudam a diminuir a desigualdade e abrir um pouquinho de acesso, né? Pra esse povo que de alguma forma é excluído a ter um pedacinho de chance na vida (Entrevistada MW).

No tocante a isso, podemos afirmar a importância que essas mulheres dão a essas políticas e como essas foram importantes em suas trajetórias. Elas ainda ressaltam como a questão financeira e desigual à qual estavam expostas naquele momento dificultaria o processo de entrada na Universidade, caso não existissem essas políticas.

Para Jardim (2015), A desigualdade de oportunidades é um dos principais argumentos que justificam a implementação de ações afirmativas no Brasil ( $p$. 114), assim podemos destacar abaixo a fala de duas entrevistadas, ratificando a importância dessas políticas:

\begin{abstract}
Ah, eu acho muito importante! Muito importante para as pessoas que não têm a possibilidade de entrar, não têm perspectiva, eu não tinha perspectiva; sempre quis fazer faculdade, mas não via possiblidade, né, eu não conseguia passar pra faculdade pública, né, e também não conseguia pagar, ter um salário pra pagar uma faculdade privada, então, foi através do ProUni que eu tive a oportunidade de ingressar no ensino superior, de ter uma formação a nível superior e conseguir no futuro ter uma profissão, conseguir trabalhar e conseguir trabalhos melhores, empregos né, na área em que eu me formei. Então pra mim, foi muito importante e é muito importante, acho que é essencial para as pessoas que não têm condições e que moram e crescem nas comunidades (Entrevistada VL).
\end{abstract}

Eu acho que é válido, eu acho que a pessoa pobre precisa, sabe? Dá uma ajuda pra eles, porque não adianta falar que é só estudar. Gente, não é a mesma bagagem de estudo de uma pessoa que veio de uma escola particular o tempo todo, desde pequeno, estudando em escola particular e você ali numa escola pública, não tem a mesma quantidade de matérias, só pelo IBMEC eu pude ver ali a quantidade de coisas, tipo assim, de matérias pra fazer, a quantidade de trabalho e tudo mais. As pessoas que faziam o curso, eram pessoas mais de poder aquisitivo mais alto e elas não trabalhavam, elas só estudavam e elas tinham os pais pra poder dar uma ajuda, tipo comprar os livros, a manter a faculdade, a pagar, eles falavam "ah, depois da aula, vamos estudar? Depois da aula vamos fazer isso, vamos fazer aquilo?" E você fica pensando, "não, depois da aula eu tenho que trabalhar" (Entrevistada VB).

Com a fala das entrevistadas, podemos destacar como a desigualdade de oportunidades e o fato de serem oriundas de classes populares, interferiram diretamente no ingresso das mesmas no espaço universitário. Assim, a adoção de políticas que minimizem as desigualdades sociais existentes e diminuam a situação de exclusão à qual essas mulheres estão expostas, mostram-se de extrema importância. Para Joaquim Barbosa Gomes (2001), as políticas de ação 
afirmativa possibilitam uma maior igualdade de condições, ainda de acordo com o autor,

(...) uma noção «dinâmica», «militante» de igualdade, na qual necessariamente são devidamente pesadas e avaliadas as desigualdades concretas existentes na sociedade, de sorte que as situações desiguais sejam tratadas de maneira dessemelhante, evitando-se assim o aprofundamento e a perpetuação de desigualdades engendradas pela própria sociedade. Produto do Estado Social de Direito, a igualdade substancial ou material propugna redobrada atenção por parte do legislador e dos aplicadores do Direito à variedade das situações individuais e de grupo, de modo a impedir que o dogma liberal da igualdade formal impeça ou dificulte a proteção e a defesa dos interesses das pessoas socialmente fragilizadas e desfavorecidas (Gomes, 2001, p.131).

Ainda sobre as políticas de ação afirmativa, Jardim (2015) nos relata que,

De fato, o acesso de estudantes pertencentes a grupos marginalizados e subrepresentados às Universidades Brasileiras e ao conhecimento socialmente valorizado é incrementado pela adoção de políticas de ação afirmativa. O enfrentamento das desigualdades sociais no Brasil torna-se urgente, bem como a viabilidade de políticas que possam concorrer para a instituição de uma sociedade sem qualquer tipo de discriminação (Jardim, 2015, p. 115).

Outro ponto que podemos destacar, é a importância da Assistência Estudantil para os alunos da classe trabalhadora, mesmo que cinco (5) das sete (7) entrevistas não tenham recebido nenhum tipo de assistência, cabe ressaltar as dificuldades financeiras que as mesmas passaram durante o curso e como essa política, sendo mais ampliada, poderia ter contribuído para uma passagem mais confortável, financeiramente falando, durante o período dessas mulheres dentro da universidade.

Esse depoimento expressa isso muito bem a informação acima:

Então, a gente tinha direito à bolsa-permanência, na verdade era bolsa cotista e aí essa bolsa durava um ano, assim que a gente entrava, eu entrei em 2008, em 2009.2 ia acabar a minha bolsa, eu me lembro que na época como eu estudava à tarde, eu consegui vaga pra tarde, eu não trabalhava, então, eu fiquei desesperada, eu entrei já pensando: "como vão ser os próximos semestres quando a bolsa acabar?" Eu acho que, na época, era $R \$ 200,00$ reais que eles ajudavam, então, dava certinho pra minha passagem do mês e comprar as xerox, não dava pra fazer mais nada, nem lanche, nem nada, mas eu conseguia manter assim certinho, eu lembro que eu chorava muito, "meu Deus será que eu vou conseguir?" "Será que eu vou conseguir me manter aqui?" (Entrevistada MW). 
A entrevistada prossegue apontando para as dificuldades financeiras vividas durante o curso de graduação, do problema do formato das universidades públicas que privilegiam o estudante que não é da classe trabalhadora, pois trata-se de uma Universidade que foi feita para formação da elite, assim, podemos destacar, no final da fala da ex-aluna, a importância da Assistência Estudantil $(A E)$ para a permanência do aluno de classe popular no espaço universitário.

\begin{abstract}
(...) pra eu conseguir mudar pra noite, foi um processo bem grande, porque lá na UERJ, principalmente no curso de Psicologia, você não tem disponível o mesmo período, por exemplo, 2020.1 é o primeiro semestre 2020.2, no próximo semestre é à noite que seria o primeiro período, então, nunca batia as disciplinas, eu tinha que atrasar um período pra conseguir a disciplina, tipo assim, uma turma anterior, eu não conseguiria puxar matéria no mesmo período porque eles não ofereciam, eles só abriam duas turmas, enquanto que pra Pedagogia, eles abrem acho que oito ou dez, pra Psicologia são só duas turmas por ano, 45 no primeiro semestre e 45 vagas no segundo semestre, então, não tinha como eu mudar, assim, eu pensei, um pouquinho antes, eu entrei para aquele 'Jovem Aprendiz'? Foi na época que eu tava fazendo pré-vestibular, foi um pouquinho antes, eu assinei minha carteira como Jovem Aprendiz, ganhando menos que meio salário mínimo e entrei, logo depois do Jovem Aprendiz, quando eu entrei na UERJ eu tava finalizando a época do Jovem Aprendiz, foi isso, acabava o contrato, não tinha como eu ficar. Na época, eu fiz pra Telemarketing, porque o horário do Telemarketing era um horário diurno e minha faculdade também, aí eu falei: "vou me segurar com a bolsa, vou tentar passar pra noite e ver o que eu vou fazer", aí, um ano depois, quando acabou a minha bolsa, a UERJ instituiu a bolsa permanência, em que essa bolsa seria válida por todo o curso, aí foi quando eu consegui relaxar de que pelo menos eu saberia que ia conseguir chegar até a Universidade e tirar minhas xerox, mas até então, foi bolsa cotista, foi bem no meu ano (Entrevistada MW).
\end{abstract}

A Assistência Estudantil, enquanto política pública é bem recente, porém, a discussão é antiga, foi uma política construída a partir de um processo de ampliação e democratização do acesso e permanência no Ensino Superior, assim, de acordo com Dutra e Santos (2017),

Dentro desse contexto, a assistência estudantil $(A E)$ vem ganhando relevo nas discussões promovidas pela comunidade acadêmica, além de ganhar espaço na agenda do Governo Federal, que a elevou recentemente ao status de política pública, através do Decreto no 7.234 de 19 de julho de 2010 (BRASIL, 2010), instituindo o Programa Nacional de Assistência Estudantil - Pnaes (Dutra; Santos, 2017, p. 148).

Ainda sobre a $\mathrm{AE}$, as autoras destacam que,

Apesar de atualmente a assistência ao estudante assumir papel de centralidade para o Estado brasileiro na estratégia de combate às desigualdades sociais e regionais através da democratização da Educação Superior (MEC, 2013), cabe destacar que esse espaço foi conquistado, resultado de intensas lutas sociais, encabeçadas principalmente pelo movimento estudantil, organizado pela União Nacional dos Estudantes (UNE), e pelo Fórum Nacional de Pró-reitores de Assuntos 
Comunitários e Estudantis (Fonaprace). Essas constituem as principais entidades engajadas na luta por uma AE como direito social e como política pública (Dutra; Santos, 2017, p. 149).

Destaca-se, nesta discussão, a importância de que haja uma política que não somente dê oportunidade de permanência a grupos fragilizados dentro das Universidades, mas que também contribuam para a ampliação das mesmas e que possam alcançar todos os estudantes, visto que independente da questão financeira, podem trazer em suas vivências outras questões. Podemos destacar, que no grupo de ex-alunas entrevistadas, cinco (5) não foram contempladas por nenhum tipo de $A E$, mesmo em um universo pequeno, pode-se observar que na fala das entrevistadas a questão financeira e até mesmo emocional pesou durante a passagem dessas mulheres na universidade.

A Assistência Estudantil é uma política fundamental para que estudantes da classe trabalhadora permaneçam dentro das Universidades, apesar de serem políticas focalizadas, devem contribuir para que alunos oriundos da classe trabalhadora tenham uma formação de qualidade. A AE não deve apenas abarcar questões financeiras e o combate à pobreza, existem outras nuances na vida desses alunos, como questões de moradia, familiares, questões culturais e outras vulnerabilidades a que estão expostos.

Outro aspecto que podemos destacar é o fato de todas as ex-alunas entrevistadas terem feito a primeira graduação nesse período e não terem tido oportunidade anterior de ingresso na universidade.

Outro ponto importante, é o fato de que cinco (5) das sete (7) entrevistadas, dentro de seus núcleos familiares, terem sido as primeiras a pisarem em uma Universidade, sendo que duas (2) delas ingressaram simultaneamente com suas irmãs, ou seja, a primeira geração que finalmente cursou o nível superior, como podemos ver nas falar em destaque:

Não, eu fui a primeira. Não sou a única agora, porque tem mais exemplos, mas eu fui a primeira a entrar na faculdade, depois de mim, meus primos que fizeram e tal. Mas antes não! (Entrevistada MC)

Não, eu fui a primeira pessoa a entrar na faculdade, fui a primeira. (Entrevistada $\mathrm{VL})$.

Percebemos, conforme as falas acima, que a desigualdade educacional é uma questão relevante na vida das pessoas de classes populares, visto que essas mulheres foram as primeiras de muitas gerações a terem oportunidade de ter um diploma universitário. Mesmo sendo maioria no ensino superior, as mulheres, principalmente as ex-alunas do CPVC, grupo que pesquisamos, tiveram um maior 
acesso após os anos 2000, como pudemos ver, esse grupo inseriu-se no ensino superior entre os anos de 2007 e 2009.

Como dito anteriormente, as mulheres pobres vivem em um cenário de inúmeras contradições, mesmo conquistando uma vaga no ensino superior, nem sempre a trajetória dentro da Universidade é fácil, “(...) embora os dados quantitativos apontem para maior acesso das mulheres à educação superior, cabe ainda uma avaliação analítica qualitativa no sentido de observar como é a trajetória destas mesmas mulheres durante os cursos (...)" (Willeman, 2013, p. 168). Levando em consideração que as ex-alunas desempenhavam outras funções, não somente a de estudante, mas também de mulher trabalhadora, mãe, dona de casa, etc., assim, devemos avaliar também, como foi conciliar faculdade, trabalho e vida pessoal.

\subsection{Trajetória pessoal, Profissional e Acadêmica das Ex-Alunas do Pré- Vestibular Comunitário São Luiz Rei de França}

Como podemos perceber, a trajetória acadêmica das ex-alunas do PVCSLRF foi de muitas dificuldades, visto que essas mulheres são oriundas de famílias que não acumulam capitais econômicos, culturais ou sociais valorizados, e que vêm das favelas de Costa Barros, ou seja, são mulheres pobres, que vêm de uma cultura na qual estudar não é prioridade, mas sim, sobreviver, não possuem em suas famílias históricos ou exemplos de outras pessoas que tiveram a oportunidade de adquirir um diploma universitário, além de terem que trabalhar para se manterem nesses espaços.

Nota-se, pela fala das ex-alunas, que ingressar no ensino superior e conquistar um diploma universitário foi motivo de orgulho e admiração em suas famílias, mas para tal conquista, muitas barreiras foram ultrapassadas, como poderemos ver nos relatos a seguir.

Quando questionadas sobre o horário de seus cursos e se tiveram alguma dificuldade em conciliar a faculdade com trabalho (caso tenham trabalhado no período da graduação), as entrevistadas relataram as dificuldades abaixo, demonstrando como ser mulher, aluna e trabalhadora tiveram seus desafios.

Olha, acho que foi mais a transição, no início, como eu fiz o primeiro semestre de tarde, eu não estava trabalhando, no terceiro semestre, foi quando eu comecei a trabalhar, então, eu tive que atrasar um período, porque não tinha essa oferta de trabalho, porque o cansaço era grande, porque eu acordava muito cedo pra trabalhar, trabalhava o dia todo e ia correndo pra universidade e ficava lá até quase 
onze horas, pra voltar pra casa e acordar cedo, toda essa rotina, foi exaustivo, mas valeu à pena (Entrevistada MW).

O turno era de manhã e eu fazia o estágio na parte da tarde. Era um pouco complicado, porque né casava muito, o horário era muito apertado. Eu tinha que estar no centro da cidade uma hora, eu saía da faculdade 12:30 e eu tinha que "tá" uma hora ali na Presidente Vargas, quando eu estagiei na ANAC e o outro era mais difícil ainda, que eu tinha que ir pra Botafogo. Então, eu sempre chegava atrasada e eu era chamada atenção, mas eu tinha que cumprir minha carga horária da faculdade. E o que dificultava é que eu tinha ainda que, com esse valor do estágio, arcar com passagem e material de estudo (Entrevistada I).

Sim, eu estudei à noite, fazia o curso à noite e tinha dificuldade pra conciliar o horário, porque eu trabalhava em Copacabana, depois eu fazia um estágio lá pra Zona Norte, então era cansativo, a dificuldade era o cansaço e também como eu larguei o trabalho pra poder estagiar, minha bolsa de estágio era muito pouca, então acabava que eu tinha que pagar pra trabalhar né, e tinha pouco dinheiro pra ir pra faculdade, minha mãe quem me ajudou muito na época. Então, a minha dificuldade foi financeira, pra pagar passagem e tudo mais, pra custear a faculdade, algumas coisas né, que precisava comprar na faculdade e também o cansaço, o rendimento era baixo, por isso, pelo cansaço de ter que trabalhar e estudar (Entrevistada VL).

Percebemos uma questão extremamente relevante nos depoimentos acima, que as dificuldades em permanecerem na Universidade não eram apenas financeiras, mas também pela questão do cansaço físico, visto que muitas dessas ex-alunas exerciam múltiplas funções, trabalhavam fora, numa carga horária exaustiva.

Devemos salientar aqui, sobre a questão do bairro onde elas moravam. Costa Barros não tem muitas opções de transporte público, principalmente no período noturno, o que fez com que essa trajetória tivesse sido ainda mais cansativa, levando em consideração que as Universidades em que estudavam, eram distantes e com carga horária mais ampliada, o que fazia com que, como elas relataram, chegassem em casa tarde e acordassem cedo para trabalhar no dia seguinte e exercer suas outras funções de mãe, dona de casa, trabalhadora, etc. Para Saffioti (1987),

(...) a responsabilidade última pela casa e pelos filhos é imputada ao elemento feminino. Torna-se, pois, clara a atribuição, por parte da sociedade, do espaço doméstico à mulher. Trabalhando em troca de um salário ou não, na fábrica, no escritório, na escola, no comércio, ou a domicílio, como é o caso de muitas mulheres que costuram, fazem crochê, tricô, doces e salgados, a mulher é socialmente responsável pela manutenção da ordem na residência e pela criação e educação dos filhos. Assim, por maiores que sejam as diferenças de renda encontradas no seio do contingente feminino, permanece esta identidade básica entre todas as mulheres.

A sociedade investe muito na naturalização deste processo. Isto é, tenta fazer crer que a atribuição do espaço doméstico a mulher decorre de sua capacidade de ser mãe (Saffioti, 1987, p. 9). 
A partir da fala das ex-alunas, podemos constatar algumas dificuldades em suas trajetórias acadêmicas, que se deu, principalmente, na permanência. Não basta acessar ao ensino superior, o aluno vindo de classes populares também acaba tendo que criar estratégias para permanecer nesses espaços e isso vai desde conseguir dinheiro para passagem, xerox, livros, a participar das atividades extracurriculares oferecidas pela universidade, etc. Isso fica claro nas falas das entrevistadas abaixo:

No acesso à faculdade, a maior dificuldade foi, é claro, se não fosse por meio do Pré-vestibular São Luiz, eu acho que nem conseguiria, talvez hoje, hoje talvez eu conseguiria fazer uma faculdade, hoje com todos os projetos e as bolsas que existem por aí, mas era a parte econômica (a maior dificuldade), o acesso à faculdade era bem complicado, às vezes me faltava recurso de passagem né, às vezes eu tinha que usar o bilhete escolar do meu filho até Cascadura e de Cascadura ir a pé até Piedade, porque lá eles não permitiam, eles faziam "cara, crachá" e eu não podia chegar lá (Entrevistada I [Grifos meus]).

No acesso, eu acho que primeiro a preparação, que eu acho que a gente não tem, deveria ter dentro da escola pública, a gente vê provas assim bem diferentes do que a gente estuda, do que oferecem pra gente, mas aí eu não sei se eu vou criticar a prova ou o formato dentro da escola, porque tem muita coisa que a gente for ver de conteúdo, a gente sabe que não usa no nosso dia a dia, mas enfim, eu acho que o conteúdo e a preparação foi uma dificuldade, tanto que eu tive que recorrer a um pré-vestibular, porque eu não tive uma escola que me preparasse pra isso é lá dentro.

O que eu senti dificuldade, acho que por eu estar trabalhando, não tive acesso às pesquisas que eu gostaria de fazer, todas as pesquisas, todos os professores que encaminhavam pesquisa, que eram coisas que eu sei que futuramente, após a saída, já iriam me ajudar a ingressar tanto num mestrado, quanto numa pós, eu não tive acesso, porque eu precisava trabalhar, não tinha como eu estar numa pesquisa e trabalhando ao mesmo tempo, então, eu acho que dentro da Universidade, essa falta de tempo, o trabalho acaba tirando um pouquinho essa oportunidade de mergulhar totalmente na Universidade. Eu gostaria? Gostaria! Mas não podia, porque tinha que trabalhar.

Eu via os projetos de pesquisa que eu queria trabalhar, mas infelizmente, não tinha como né, a necessidade falava mais alto e eu optei em trabalhar né, estudar e trabalhar, então, eu tinha que conciliar e a vida tinha que ser dividida pra isso, mas no primeiro semestre eu cheguei a entrar numa pesquisa, de mulheres que estavam presas dentro do DEGASE, eu fui logo pra essas pesquisas assim, aí, quando eu comecei a trabalhar e pensei: "não posso mais", eu tinha que ir lá para o centro da cidade fazer reunião, aí não deu, eu tive que frear um pouquinho essa parte né, não pude aproveitar tudo o que a Universidade podia me oferecer, porque o trabalho tirava um pouquinho disso.

A pesquisa era com a professora de Psicologia Jurídica da gente e aí eu fui, nossa, muito legal, assim, você viver as histórias e eu chorava, as mulheres, que tinham os nenéns e tinham que entregar, era triste, justamente porque na penitenciária feminina tem muito isso, enfim, aí eu tive que parar, porque eu comecei a trabalhar e aí não deu. Mas seria uma área que eu iria escolher dentro da Universidade, tem coisas muito interessantes, bacanas. Eu acho que se eu estivesse um pouquinho mais de estrutura familiar, eu conseguiria, mas eu não tinha, nem quem desse a passagem, graças a Deus a universidade que deu, porque senão, nem isso, eu ia ter que me virar, arrumar um jeito de trabalhar logo de início, se não tivesse bolsas, pra conseguir me manter, então... (Entrevistada MW) 
Podemos perceber que as dificuldades na trajetória acadêmica eram muitas, existem barreiras intransponíveis para essas mulheres, que não somente estratégias dariam conta de ultrapassá-las, mas sim, políticas públicas que fossem eficazes para esses grupos. Como é o caso da $A E$, podemos ver abaixo o quão importante essa política foi para a ex-aluna, pois a mesma não tinha condições de trabalhar no período inicial da graduação, já que seu horário era diurno, o que seria outra problemática da universidade pública, que não foi formatada para receber estudantes pobres, que trabalham ao longo do dia para garantir seu sustento.

\begin{abstract}
Nossa, como eu fiquei aliviada quando essa bolsa se tornou permanência, porque, agora, é chamada de bolsa permanência, eu falei: "gente, eu vou poder chegar na Universidade", porque, assim, o grande problema é o que todo mundo fala, você às vezes consegue chegar na Universidade, mas você não consegue se manter e com esse projeto dentro da UERJ, nossa, eu acho que foi a salvação de muitos. $\mathrm{Na}$ minha época, não tinha bandejão, foi ter, eu acho que já no meu último ano da UERJ e aí eu vi, "poxa", comida a $R \$ 2,00$ reais", e que comida! Nossa, melhor do que os restaurantes que você vê por aí, proteínas... Gente, por que não teve isso desde o início e eu aqui passando fome? Porque eu não podia ficar comprando salgados caros, aquela comida bem balanceada, muito bacana e eu nem pude aproveitar tanto o bandejão, porque foi no penúltimo ou no último período que eu tava por lá. É uma boa, para os alunos que estão lá e precisam se alimentar, porque olha, vou te falar, a turma então, eu falava: "G, como tem dinheiro?, eles vão lá e voltam com aquele 'potão' de açaí, você está com fome, passa o dia todo dentro daquela universidade", eu falei, você não ter dinheiro pra comprar um salgado, era complicado, mas, a gente tinha um objetivo, então, tinha que regular o pouco dinheirinho que tinha, ainda mais nos primeiros semestres, que eu não trabalhava e muita gente que ia pra tarde, era gente que os pais tinham condições, então, assim, pra eles era natural, pra gente que tava ali, não.

O meu horário era de meio dia às cinco, então, era bem no meio, não podia nem trabalhar de manhã, nem trabalhar de noite, se fosse pelo menos de manhã, eu podia tentar alguma coisa, pegando de duas às dez, mas nem isso, por isso, eu tive que mudar pra noite, não tem Psicologia de manhã na UERJ, só à tarde ou noite (Entrevistada MW).
\end{abstract}

Outra dificuldade apontada pelas ex-alunas foi tanto no acesso, quanto na questão da permanência na Universidade, seria em relação às informações. $A$ população pobre vive excluída do acesso a bens, serviços e informação, e como estamos falando de um período em que nem todos tinham internet em casa e esse tipo de serviço era bem mais restrito, ficava tudo ainda mais complexo na vida dessas mulheres, por este motivo, o CPVC foi também, instrumento de informação para esse público. Podemos ver essa questão, a partir da fala de uma das entrevistadas, segue trecho:

A maior dificuldade realmente de ter acesso é alguém que informasse como chegar até lá. Eu não tinha ideia, até entrar no pré-vestibular, eu nem sabia, eu fui numa missa e aí o Padre falou que ia ter esse pré-vestibular, mas eu também nem sabia 
do que se tratava até chegar lá e o Fabinho me explicar e explicou tudo, o quê que ia acontecer e tal. Então, eu acho que a maior dificuldade é essa, é não ter nenhum tipo de acesso, nenhum tipo de conhecimento. Eu não tinha, na época, lá no morro, nas escolas que eu frequentei, a minha escola não falava "ah, você vai fazer o ENEM, vai fazer faculdade", na época não tinha o ENEM, na minha época lá que eu terminei, em mil novecentos e 'lá vai bolinha', então, eu acho que a maior era essa, $o$ acesso (Entrevistada MC).

Sobre a questão das dificuldades ao longo da faculdade, a entrevistada complementa:

(...) durante a faculdade, acho que foi mais no primeiro ano mesmo, como te falei, eu trabalhava integral, então, era bem chato chegar na faculdade e sair tipo, dez horas da noite e chegar em Costa Barros uma hora da manhã, do Rio comprido até Costa Barros era bem complicado, tinha que chegar de metrô, às vezes não tinha metrô, terminava meia noite e às vezes a faculdade terminava dez horas e eu saía correndo, nem terminava a aula e eu saia correndo (...) (Entrevistada MC).

Outro ponto destacado nas entrevistas, foi a questão da qualidade do ensino básico e as dificuldades em fazer a prova do vestibular/Enem devido ao ensino defasado.

Eu acho que pra mim, com relação ao acesso (acesso a conhecimento), eu acho que a questão da bagagem educacional, eu acho que era pouca, eu acho que eu tinha pouco conteúdo, pouco aprendizado, eu acho que essa foi a maior dificuldade, eu acho que eu tinha que estudar mais, eu tinha que aprender mais, pra poder conseguir fazer a prova (do vestibular) e tudo (Entrevistada VB [Grifos meus]).

Sim, a minha maior dificuldade pra acessar (a universidade) foi conseguir aprovação né, conseguir estudar e conseguir ser aprovada, por conta do ensino precário que eu tive antes, né (Entrevistada VL [Grifos meus]).

Como podemos observar, diversas são as dificuldades enfrentadas por essas mulheres para ingressarem e permanecerem na Universidade, a questão financeira é um ponto central trazido por elas em muitos momentos.

Para Heringer (2018),

As experiências de ação afirmativa, juntamente com a expansão do sistema durante os anos 2000 promoveram maior inclusão, porém ainda há muitos obstáculos a serem ultrapassados. Os problemas se concentram nas dificuldades enfrentadas pelos estudantes de menor renda para permanecer na universidade, principalmente do ponto de vista das dificuldades financeiras (Heringer, 2018, p. 13).

Do grupo que entrevistamos, pode-se perceber que todas, de alguma maneira, recebeu ajuda da família, fosse de apoio emocional ou financeiro, no entanto, o mais pontuado foi o auxílio de suas mães nessa trajetória. O que nos mostra como as mulheres se organizam e se apoiam, visto que mesmo essas 
mães tendo pouco para compartilhar com suas filhas, conseguiram de alguma maneira ajudá-las na jornada Universitária.

\begin{abstract}
Ah, minha mãe me ajudava com a passagem, alimentação eu já comia em casa, porque eu saia meio-dia e vinha embora, mas com certeza minha mãe (ajudava), pra passagem e xerox (Entrevistada SM [Grifos meus]).
\end{abstract}

Sim, minha mãe me ajudava com a passagem e, às vezes, me dava um trocadinho a mais pra pagar um lanche (Entrevistada VL).

Como apontado anteriormente, o apoio materno foi fundamental para as exalunas entrevistadas, que vieram de famílias com histórico escolar reduzido. Os anos em que seus antecessores frequentaram à escola foram poucos em relação às suas filhas, até mesmo àquelas que vieram de ambientes familiares em que não havia valorização escolar, tiveram amplo apoio de suas mães, o que nos faz acreditar que, no período da graduação, ter um ponto de referência que Ihes ajudavam com passagem, xerox, livros, alimentação, etc. foi fundamental para essas mulheres.

Sobre a trajetória universitária, as entrevistadas destacam como foi o sentimento de ingressar numa universidade, mesmo em alguns casos não havendo o retorno financeiro esperado, o ganho cultural, intelectual e pessoal são destaques em suas falas. Outro ponto que analisamos, foi o fato dessas ex-alunas se sentirem realizadas com o seu diploma e como esse é motivo de orgulho para elas, que trouxe um significado concreto de mudança de sua perspectiva de vida, pois vinham de uma localidade em que as pessoas não tinham por hábito cursar uma Universidade, nem oportunidade de acessar a outros níveis de conhecimento.

Então, foi como se realmente fosse adentrar um outro mundo, um outro nível, de novos conhecimentos, novas práticas, de saber exatamente de que se trata um nível superior, é um pouco além de tudo aquilo que a gente já havia estudado, mas não era nada assim também tão glamoroso como eu achava que fosse, é algo que são estudos específicos de certas áreas e que ainda é, você vê a princípio você entra em um mundo novo, quando você termina você fala "cara não para só aqui, sempre você pode mais, pode mais e mais" e me percebi como muito capaz e é uma satisfação imensa de quando eu concluí o curso, falei: "caraca, eu consegui". O sacrifício foi muito grande, não tenho o retorno financeiro ainda em relação a isso, é bastante frustrante, mas foi de um prazer imenso e de uma alegria assim, sem explicação, não tem como (Entrevistada I).

Foi muito bom, foi diferente, a gente adquire muito conhecimento, não só na minha área de atuação, profissional também e pessoal também, pude aumentar o meu número de relacionamentos, comecei a conviver, antigamente não achei que fosse ter amizade com professores da universidade, então eu acho que aumentou muito o meu nível de relacionamentos, de relação, sabe, com as pessoas. Primeiro, você ter a possibilidade de sair de uma situação que você não via saída (...), antes, eu 
tinha acesso a empregos que pagavam bem pouquinho, né, eu não tinha condições de pagar pra estudar e eu não tinha condições de pagar pra fazer um curso e eu não via também que as pessoas de onde eu morava, eu via que as pessoas, como eu, que nasceram onde eu nasci, as pessoas não tinham condições de chegar em lugares diferentes, de conseguirem coisas diferentes, de conseguirem se formar, de conseguir ter uma profissão. Às vezes, faltava essa perspectiva, e a possibilidade de ter ido pra faculdade me deu essa possibilidade, de ter outro convívio social também, de ver outros lados também, de poder ter um lado crítico também mais apurado, de poder fazer críticas né, e não olhar as coisas só por um ângulo só e melhorar um pouco a nossa condição financeira, não foi muito né, mas mudou, mudou, eu pude trabalhar e ter um pouquinho de dignidade (Entrevistada VL).

Podemos analisar, de acordo com as falas das entrevistadas acima, que a vida acadêmica trouxe bem mais do que conhecimento, trouxe mudanças em suas relações pessoais, profissionais e acadêmicas, a possibilidade de ter senso crítico em assuntos que, talvez, antes não seriam possíveis de analisar, ampliou a visão de possibilidades de continuar seus estudos, entendendo que a graduação é só o início de toda uma trajetória, além de contribuir para autoestima dessas mulheres.

Para Jardim (2015),

(...) o capital cultural incorporado baseia-se na socialização primária em um ambiente social e familiar, correspondente a uma dada posição na estrutura social, na qual os indivíduos incorporam um conjunto de disposições para a ação, o habitus familiar ou de classe. Em decorrência disso, acredita-se que este é um conceito extremamente útil para pensar as possibilidades de ruptura e transformação dessas condições a partir de uma nova inserção social: a trajetória universitária, constituindo sujeitos portadores de diploma de Ensino Superior (Jardim, 2015, p. 185).

Assim, podemos destacar que mesmo perante todas as contradições que permearam a vida social e familiar dessas ex-alunas elas conquistaram não somente conhecimento, mas também a possibilidade de mudar suas trajetórias.

Concluindo, pode-se perceber que dentre as dificuldades informadas pelas mulheres em suas entrevistas, o que mais pesou na trajetória dentro da Universidade foi a questão financeira, outro ponto que podemos destacar é o cansaço, dificuldade na locomoção, ser aluna trabalhadora, no caso daquelas que trabalhavam ou faziam estágio no período da graduação, etc.

A formação universitária e mobilidade social:

Podemos destacar, que com a formação universitária, as ex-alunas conquistaram outros níveis de cultura e conhecimento. Pode-se dizer que a partir do acesso universitário essas ex-alunas conquistaram alterações relevantes em 
sua estrutura social e familiar, fazendo com que as mesmas tenham conquistado mobilidade social, tendo sido financeira, cultural, social ou até mesmo geracional. Quando questionadas se consideravam que obtiveram mobilidade social após a conclusão do ensino superior, algumas das ex-alunas sinalizaram que sua mobilidade não foi econômica, mas sim, cultural e intelectual. Outro ponto bastante falado por elas é o fato de ter tido a oportunidade de ter contato com pessoas de outras culturas e outras camadas sociais, além do fato de passarem a ter acesso a bens e serviços que antes não poderiam adquirir, como destacamos abaixo:

(...) cultural, sim; econômica, não, porque eu não tive a oportunidade de me inserir na minha área, porque sempre pediam ou cursos ou experiência e a parte que eu tive experiência foi na área hospitalar e precisava sempre de pós ou algo a mais (Entrevistada I).

(...) E lá eu comecei a abrir minha cabeça pra um monte de coisa que nem eu sabia que queria, no caso. Eu tive, fotografia na faculdade, foi quando eu comecei a gostar de fotografia, tive artes, tudo o que foi melhorando minha cabeça, desenvolvendo minha mente, pra algum norte assim né, do que eu quero fazer, coisas que eu gosto, que antigamente era um pouco mais travada, meio perdidona, no caso. Foi um pouco intelectual (a mobilidade) (Entrevistada SM).

Sim, sem sombra de dúvidas, uma diferença enorme. Primeiro acesso, né? Você acaba tendo contato com outras pessoas, de outro mundo, porque a gente faz a faculdade particular né, no meu caso, então, você tem acesso a outro tipo de pessoas, pessoas que já trabalhavam, pessoas mais velhas, pessoas mais novas e culturas diferentes, às vezes a gente fica só naquele mundinho ali, na nossa comunidade e eu não era muito de sair, isso me ajudou muito, as pessoas me mostravam muitas coisas é, acesso a teatro, que na própria escola tinha, na própria faculdade na época, falava-se sobre teatro, sobre... nossa, muita coisa, outros tipos de coisas, que a gente não tinha acesso no nosso dia a dia, internet, computadores, na minha época, na nossa época, lá pra trás, a gente não tinha muito isso e na faculdade já te dava essa liberdade de você chegar e ter um computador pra você estudar, eu não tinha, no entanto, eu tive que comprar durante a faculdade, eu trabalhando, consegui comprar um computador, mas, enfim, abriu muito o leque pra tudo, cultura, a mente, tudo! Foi muito importante! (Entrevistada MC).

Podemos dizer que a educação foi base fundamental para que houvesse mobilidade na vida das ex-alunas do PVCSLRF. Para Jardim (2015, p. 83), “a educação - além de estratégia para redução de desigualdades e desenvolvimento social e econômico - é vista também como componente fundamental de mobilidade social".

Outro aspecto que podemos avaliar neste caso, é a mobilidade geracional no tocante à educação, das sete (7) ex-alunas que entrevistamos, ,apenas de uma (1) a mãe concluiu o ensino superior no ano de 2017, cinco (5) mães possuem apenas o ensino fundamental e apenas uma (1) o ensino médio. Ressaltando que essa concluiu depois de adulta, fazendo supletivo, ou seja, a maior parte das mães 
das ex-alunas que entrevistamos não tiveram acesso à educação, muito menos, ao ensino superior. Podemos observar também, que houve um salto de uma geração para outra, levando em consideração que a maior parte das mães das entrevistadas só estudaram até o ensino fundamental e suas filhas tiveram a oportunidade de concluírem um curso de nível superior ${ }^{13}$.

Hoje, ela tem o ensino fundamental completo, porque ela concluiu ano passado pelo PEJA (Entrevistada I).

A minha mãe, ela tem $02^{\circ}$ grau completo, ela terminou depois de adulta, ali fazendo jovens e adultos (Entrevistada MW).

A minha mãe estudou até a antiga $3^{\circ}$ série, que agora é o $4^{\circ}$ ano (Entrevistada SM).

A minha mãe era doméstica e ela só fez até a quarta série. Na época né, a quarta série primária (Entrevistada MC).

Então, a minha mãe conseguiu concluir o ensino superior ano retrasado, eu acho, foi em 2017 (Entrevistada T).

Ela tentou concluir o ensino médio, mas ela nem conseguiu, então, ela tem o ensino fundamental completo (Entrevistada VL).

(...) eu acho que minha mãe não tem segundo grau não, minha mãe estudou, mas acho que ela só fez até a oitava série (Entrevistada VB).

Outro ponto que devemos analisar é que, apesar das mães das ex-alunas terem um baixo grau de escolaridade, essas mulheres romperam com a perspectiva de que, mesmo tendo mães com baixa escolaridade, as filhas reproduziriam o mesmo modelo, sendo assim, podemos dizer que houve mobilidade geracional no que diz respeito à educação e que essas mães apoiaram suas filhas na trajetória universitária.

Sobre a profissão de suas mães, comparada às profissões das ex-alunas, podemos ver abaixo que duas (2) são Do lar, ou seja, não trabalham fora; duas (2) são domésticas; uma (1) é operadora de caixa; uma (1) é Auxiliar de Serviços Gerais; e uma (1) trabalha na área de gestão, enquanto suas filhas são, Administradoras, Psicólogas e Professora de Letras.

\footnotetext{
13 "A interpretação dos níveis de mobilidade social, principalmente ascendente, é vista como um importante indicativo de que uma determinada sociedade vai bem, e é socialmente promissora. Fatores como esperança, perseverança e motivação em projetos de desenvolvimento coletivo estão relacionados ao fenômeno da mobilidade social em sua totalidade. O estudo da mobilidade torna possível a identificação de rotas, de bloqueios, de sucessos e fracassos que podem ser sistemáticos e, portanto, passíveis de serem trabalhados. Dessa maneira, a mobilidade social inscreve-se no campo de estudo das desigualdades, na medida em que esclarece processos de cristalização ou redistribuição, permanência ou mudança nas chances de alocação na estrutura social" (Jardim, 2015, p. 85).
} 
Podemos também, neste caso, ver um avanço no que diz respeito às profissões dessas duas gerações de mulheres. Assim, segundo Jardim (2015, p. 84), "a escolarização superior passa a ser um recurso que qualifica a força de trabalho, habilitando-a a disputar empregos melhor remunerados, revestidos de alto valor simbólico, e a competir por posições hierárquicas mais elevadas no mercado de trabalho".

Como podemos ver abaixo na fala das entrevistadas, houve um salto no que diz respeito a profissão delas, em relação ás suas mães.

\author{
Do lar (Entrevistada I). \\ Doméstica (Entrevistada MW). \\ Operadora de caixa (Entrevistada SM). \\ Doméstica (Entrevistada MC). \\ Trabalha na área de gestão (Entrevistada T). \\ Do lar (Entrevistada VL). \\ Auxiliar de Serviços Gerais (Entrevistada VB).
}

Quando questionadas se trabalhavam em suas respectivas áreas de formação e caso não trabalhasse, se houve algum fator que tenha dificultado essa alocação, percebemos na fala das entrevistadas que o fato de serem mães interferiram de alguma maneira em suas carreiras profissionais, conforme relatos abaixo.

Sobre trabalhar na área de formação, as ex-alunas nos traz que:

Não. Só fazer uma graduação não basta. Precisa de ter experiência, mas como ter experiência se não te dão oportunidade? (Entrevistada I).

Trabalhei, no momento, eu não estou trabalhando (Entrevistada MC)

Elas complementam com a questão da maternidade e como tiveram que fazer determinadas escolhas em detrimento de seus filhos:

Outro ponto é que tendo 2 filhos pequenos, eu tive que trabalhar naquilo que não era tão exigente e me dava tempo para ser mãe também. $F$ ficava muito doente de bronquite e pneumonia. Tive que me dividir, sem ousar muito. E o tempo passou e a lacuna entre minha formação e exercer a função. A lacuna só aumentou. Agora, exigem pós (Entrevistada I).

(...) mais por uma questão pessoal, por conta da pequena, mas sim, eu tava trabalhando até dezembro do ano passado, na minha profissão, em Administração (Entrevistada MC). 
Podemos perceber que, para as ex-alunas, não basta ter um diploma universitário, essas precisam de uma rede de apoio ainda mais ampla, para que possam ser profissionais e investir em suas carreiras, visto que, em via de regra, a responsabilidade na criação dos filhos acaba sendo sempre da mulher.

Outro ponto que podemos observar é a questão das exigências do mercado, não basta apenas ter o diploma de nível superior, mas experiência e quem sabe até especializações. Como sabemos, o mercado de trabalho é restrito, além do fato do desemprego estar em alta, nem sempre as empresas querem contratar mulheres e o fato de terem filhos dificulta ainda mais a inserção delas no mercado de trabalho formal, o que não contribui para que essas ex-alunas tenham experiência e nem dinheiro para investir em suas carreiras e numa formação continuada.

Quando questionadas sobre o impacto de uma formação universitária em suas vidas, as ex-alunas nos trouxeram diversas formas de impacto após a conclusão de seus cursos de nível superior, como por exemplo, aquisição de conhecimento, autoestima, dar orgulho a sua família, mudar o rumo da sua própria trajetória por meio da educação, dentre outros quesitos.

Para Williman (2013), “(...) conseguir vencer o desafio construído socialmente como algo inacessível para a população mais pobre parece mais um objetivo em si mesmo do que um meio para alcançar perspectivas de concretização intelectual, política, artística ou profissional” (p. 219). Podemos ver abaixo alguns dos impactos citados pelas ex-alunas após a conclusão de seu curso de nível superior:

Impactos na autoestima:

Eu acho que o primeiro é emocional, como era uma coisa que eu desejava muito, eu acho que ia ficar muito mal, muito depressiva se eu não conseguisse, então assim, emocionalmente, pra mim, foi um ganho assim, uma coisa que em toda a minha trajetória acadêmica, desde que eu me entendo como pessoa e gente, eu sempre busquei, eu sempre quis isso, eu queria ter um ingresso na universidade, particular ou onde fosse, ter uma profissão assim, então, quando eu consegui, o primeiro impacto eu acho que foi uma realização pessoal, hoje em dia, como eu falei, eu acho que talvez, se eu tivesse uma orientação maior, não é que não faça diferença, mas eu acho que talvez a ordem da coisa seria diferente, eu talvez daria prioridade pra um concurso, porque a gente que é pobre é complicado ficar na CLT e nem a CLT hoje em dia tem, por conta dos contratos né, então, talvez, eu mudaria isso, mudaria a importância das coisas, porque a faculdade a gente percebe que não é garantia financeira; um concurso, a gente já tem uma garantia financeira, e assim, eu nova, sem ninguém concursado na família, sem ninguém ter passado por uma faculdade, eu não tinha essa orientação, e assim, na minha cabeça era "vou conseguir estar na faculdade, vou conseguir me estabilizar", e é um engano, né? Porque você fazer faculdade não quer dizer estar estável, então assim, eu procurei fazer faculdade e o processo acabou sendo em ordem diferente, mas valeu a pena 
de qualquer forma, foi bom, eu acho que me ajudou até a ter estabilidade, mas eu acho que só inverteria mesmo a ondem, mas foi bom o processo, eu acho que foi bom a minha formação como pessoa, conhecer outras pessoas, conhecer outro mundo além da pedreira aqui né, porque isso te abre caminhos né? Te abre e você passa a conhecer mais pessoas, começa a conhecer outras realidades, isso aí não é o conteúdo da Universidade em si, é tudo o que ela te traz, eu acho que isso faz uma mudança na sua vida, uma mudança de perspectiva, a coisa se amplia e é bom por isso, eu acho que me abriu caminhos, me abriu caminhos pra conhecer diversas pessoas, enfim, gosto, gostei, fez sentido, ela me deixou mais feliz com ela (Entrevistada MW).

O impacto foi de você poder ver outra realidade, o impacto foi esse, de mudar a minha realidade, a minha perspectiva de vida, antes eu achava que eu não ia conseguir ter uma profissão, que eu ia crescer ali na favela, que eu ia crescer ali e que eu tinha que trabalhar sempre assalariada, depois que a gente se forma, a gente também é assalariado, mas você vê que existem outras opções, que você pode buscar, você consegue ver outras coisas, você consegue ver outras possibilidades, eu acho que foi esse o impacto e que também é necessário ajudar as pessoas para que elas tenham mais acesso ao ensino superior, para que elas também possam mudar de vida, eu acho que esse foi o impacto, da gente ver como é importante e como é necessário em ajudar as pessoas e ver que elas precisam disso, elas podem, elas podem e vão conseguir fazer, porque antes eu achava que eu não ia conseguir e graças a essa ajuda, eu consegui, entrar na faculdade, e tem pessoas que não tem essa perspectiva, eu também não tinha, de que eu ia conseguir fazer uma faculdade, né. Inclusive, a maioria dos meus familiares não fizeram.

Eu posso acrescentar uma coisa? O impacto também que tem é impacto na sociedade, né, quanto mais pessoas entrarem na Universidade, eu acho que há uma possibilidade de que o país melhore, sabe? Quanto menos pessoas tiverem acesso à educação, mais difícil fica, então eu acho que também há um impacto não só na nossa vida, mas também no país, com pessoas com mais acesso à educação (Entrevistada VL).

\section{Orgulho para seu grupo familiar:}

Foi enorme, porque a primeira mulher, a primeira menina, a primeira pessoa da minha família, tanto do lado de pai e de mãe, apesar de eu não ser registrada no nome do meu pai, eu conheci a família do meu pai, primos mais velhos, não tinham faculdade, ninguém falava sobre isso, falava em trabalhar né? Fazer 15/18 anos e ir trabalhar né? Então, eu acabei quebrando essa trajetória da minha família, como eu falei, eu fui a primeira a fazer e realmente eu chegava muito tarde e tinha que acordar cedo pra ir trabalhar no outro dia e tinha a questão do perigo, mas como a $V$ me ajudava, a gente se ajudava, se apoiava, os meninos iam buscar a gente no trem, no metrô, enfim, e foi impactante, até hoje, assim, tenho primos que estão fazendo agora, mais novos, porque foi um exemplo né, que a gente vem trazendo o exemplo de que é bom, de que trouxe coisas positivas, eu consegui coisas materiais também, coisas pra minha vida e eles acabaram vendo que isso é bom, não só ficar naquela coisa, na mesmice, sair do segundo grau e ir trabalhar em qualquer coisa, se motivar a fazer coisas diferentes (Entrevistada MC).

O impacto, pra mim, foi grande. Primeiro, por eu ter conseguido me formar né, e deixar a família orgulhosa, e intelectualmente eu ficar mais desenvolvida, aprender coisas novas, conhecer professor, conhecer a galera universitária, coisa que eu não pensava antes, não me imaginava, então, o impacto foi grande, em relação a isso por estar em um local que eu não imaginei que eu estaria e dar orgulho pra família e querer mais, entendeu? (Entrevistada SM). 
Adquirir conhecimento por meio da educação:

Eu acho que o impacto foi positivo, principalmente na nossa realidade, assim é no nosso cenário, porque a defasagem na educação é muito grande e assim, são poucas as pessoas do nosso convívio social, eu digo assim, do nosso convívio, da nossa realidade, do lugar de origem né, é o impacto foi super positivo nesse aspecto, porque me possibilitou, assim uma realização profissional e também na questão de é... abrir portas para o mercado de trabalho, porque, hoje em dia, ainda tem essa questão do currículo da Universidade Federal contar muito, então, as pessoas ainda valorizam muito isso.

E também conhecimento, né? Aquisição de conhecimento também (Entrevistada T).

Como podemos perceber, diversos são os impactos de um curso de nível superior na vida das ex-alunas do Pré-vestibular Comunitário São Luiz Rei de França, tanto no âmbito pessoal, emocional, familiar e profissional. No caso dessas mulheres, mesmo que algumas das entrevistadas relataram que não consideram ter havido alteração financeira relevante após a conclusão de seu curso, pode-se perceber que há um valor simbólico nesse diploma universitário. Para a maioria delas, a educação superior era um sonho inalcançável, portanto, no momento em que se veem, de fato, com seus diplomas em mãos e uma profissão, podendo ter uma carreira profissional, passar em concursos públicos melhores remunerados, conquistar independência, etc. foi de extrema importância para elas.

Para essas ex-alunas do PVCSLRF, ingressar, permanecer e concluir um curso universitário, contribuiu para que as mesmas saíssem da condição de vulnerabilidade, conseguiu-se por meio do ensino superior ingressar em outros patamares sociais, principalmente intelectuais, essa foi uma das mudanças apontadas por todas elas durante as entrevistas.

Como podemos ver acima, muitas citaram a questão do orgulho de suas famílias como um impacto positivo de sua formação, não só pelo fato do diploma em si, mas também por terem sido as primeiras pessoas de seus núcleos familiares a entrarem numa universidade, tal fato vindo de mulheres que moram em favela é uma vitória indiscutível. 


\title{
6. \\ Considerações finais
}

\begin{abstract}
"Minha família só frequentou a universidade a partir da minha geração. Antes, nenhum parente tinha diploma de coisa alguma, e esse parecia ser também o meu destino" (Lázaro Ramos).
\end{abstract}

Retomando a trajetória inicial desta pesquisa, percebo que sua construção iniciou-se bem antes do meu ingresso no Programa de Pós-Graduação em Serviço Social da PUC-Rio, começou mesmo antes de ingressar no PVCSLRF e até mesmo no curso de Graduação em Serviço Social. Começou quando nasci moradora de favela, mais precisamente no Morro da Pedreira, numa família de nordestinos e de mulheres que resistiram para conquistarem seus espaços num ambiente machista e desigual.

Começou quando me percebi mulher, favelada e filha de um pai negro. A partir daí, entendi que somente pela educação minha trajetória seria diferente da trajetória de todas as que vieram antes de mim e comecei a trilhar um caminho nunca feito antes por ninguém da minha família, pois os estudos não eram (ainda não são prioridade e algo de valor dentro de um grupo em que se precisa trabalhar para sobreviver, e terminar o ensino médio já era "ir longe demais", e estar no ensino superior já era bem além do que qualquer pessoa da família já havia ido antes.

Ingressar numa Universidade como a PUC-Rio, me levou a outros níveis de conhecimento e cultura, ajudou a incentivar outras mulheres da minha família a ingressarem numa Universidade, além de me fazer perceber que a graduação não era o fim, mas o início de toda uma vida acadêmica que estava só começando e, então, cheguei até aqui, na entrega do manuscrito final à banca.

Durante a minha participação enquanto aluna do CPVC, comecei a perceber que a maior parte da turma era constituída por mulheres, todas moradoras de Costa Barros e das favelas que constituem o bairro e, ali, todas estavam com o mesmo objetivo: ingressarem em uma Universidade e mudar sua trajetória de vida e de sua família por intermédio da educação.

Durante a graduação não foi diferente, o curso de Serviço Social é um curso majoritariamente feminino, o que, novamente me chamou atenção para a questão de gênero, visto que a maior parte das mulheres da turma eram oriundas da classe trabalhadora e enfrentavam infinitas questões em suas vidas pessoais, familiares 
e acadêmicas. Ainda no período de graduação, fui estagiária de Serviço Social no Banco da Providência, mais precisamente na Agência de Família Costa Barros e mais uma vez percebi que a maior parte das famílias que atendíamos tinha como chefe e principal provedora, uma mulher. Assim, surgiu o tema do meu Trabalho de Conclusão de Curso, que se intitulou "Famílias Monoparentais chefiadas por mulheres: possibilidades e limites de inserção e permanência no mercado de trabalho".

Do curso de Graduação em Serviço Social (PUC-Rio) até ingressar no Mestrado, também em Serviço Social (PUC-Rio), foram nove anos de distanciamento da academia, porém, de muita reflexão sobre o que eu já havia vivido, tanto em minha vida pessoal, quanto acadêmica, até que pudesse novamente pensar as mulheres de Costa Barros, mais especificamente as exalunas do PVCSLRF.

Portanto, para além do esforço de ingressar em um Programa bem avaliado, como é o Programa de Pós Graduação em Serviço Social da PUC-Rio, somou-se o fato desse grupo sempre ter me chamado a atenção. Assim, a partir da minha proposta inicial, ingressei no curso de mestrado e iniciei um caminho teóricometodológico para melhor desenvolver essa pesquisa, sempre com o auxílio e supervisão da minha orientadora, o que tornou a tarefa de chegar até aqui ainda mais fácil e prazerosa.

Ao longo das entrevistas, eu era a pesquisadora, mas em alguns momentos fui parte do grupo pesquisado, visto que em muitas falas das entrevistadas estavam experiências vivenciadas também por mim, não só no período da graduação, mas principalmente após a conclusão do curso.

Neste trabalho, então, o que parece marcante, é ter, de alguma maneira, dado voz a essas ex-alunas e ter dado a elas a possibilidade de nos contar um pouco de suas trajetórias após a conclusão de seus cursos de nível superior. Nos parece importante ressaltar, que todas as ex-alunas entrevistadas aceitaram o convite para participarem das entrevistas e nos deram relatos extremamente generosos de suas vidas pós-Universidade.

Desta maneira, é importante ressaltar, a forma como os capítulos foram construídos. No segundo capítulo, dissertamos sobre os pré-vestibulares comunitários, sua origem e seu conceito, após isso, contamos um pouco da história do Pré-vestibular Comunitário São Luiz Rei de França, história essa contada por dois coordenadores do CPVC. Lembrando que o PVCSLRF levava o mesmo nome da Paróquia na qual ele esteve alocado durante seu período de existência (2005 a 2010) e que de acordo com relatos de um dos coordenadores, 
o grande motivo do encerramento de suas atividades foi o alto índice de violência e as constantes incursões policiais no bairro, o que culminou com o encerramento do curso.

No capítulo 3, a respeito das desigualdades sociais e pobreza, foi possível concluir que, apesar das políticas criadas para minimizar as desigualdades existentes em nosso país, ainda existe um longo caminho a ser percorrido. Fazendo uma relação direta com a fala das entrevistadas, a questão da pobreza e das dificuldades financeiras pesaram em suas vidas, tanto no período da graduação, quanto após o término do curso, visto que não bastava apenas ter um diploma de graduação, mas também uma situação financeira favorável para continuar os estudos e dar conta do sustento de suas famílias.

Já no capítulo 4, foi possível analisar como as políticas de ação afirmativas foram importantes para a população que vive em situação de desigualdade social. Isso ficou explícito na fala de cada uma das entrevistadas, mesmo uma (1) das sete (7) entrevistadas tendo ingressado pela ampla concorrência, essa reconheceu a importância dessa política e ressaltou como elas são importantes para a população menos favorecida, trazendo minimamente a esses grupos a oportunidade de acessar ao ensino superior.

Outro ponto ressaltado por elas foi em relação à violência no bairro e a dificuldade em ser mulher e se deslocar na cidade tarde da noite e dependendo de transporte público. O que podemos ver é que a questão de gênero pesa até no momento de se deslocar pela cidade, visto as inúmeras questões as quais as mulheres estão expostas ao, por exemplo, sair tarde da noite da Universidade e cruzar a cidade para chegar em casa, num bairro periférico e com inúmeras precariedades, uma delas sendo também no transporte público.

E por fim, mas não menos importante, o capítulo no qual realizamos a análise dos dados coletados, e pudemos não somente analisar, mas fazer uma relação da fala das entrevistadas com o objetivo central deste estudo, que seria entender se de fato houve mudança na trajetória de vida das mulheres moradoras de Costa Barros e oriundas do Pré-Vestibular Comunitário São Luiz Rei de França, a partir da conclusão de seu curso de nível superior.

Sendo assim, após relacionar tudo o que foi dito pelas ex-alunas do CPVC com os teóricos ora escolhidos, pudemos perceber que a mudança ocorrida na trajetória dessas mulheres contemplam questões muito mais simbólicas do que concretas, visto que em sua grande maioria nos foi dito que a mudança ocorrida após a conclusão do curso de graduação, não foi financeira, por exemplo, mas intelectual, cultural e de absorção de conhecimento. 
O que podemos afirmar é que os nossos objetivos foram alcançados, de acordo com o que nos foi trazido nas entrevistas, esses objetivos seriam o objetivo geral, analisar a trajetória pessoal e profissional das ex-alunas do Pré-vestibular Comunitário São Luiz Rei de França, a partir da conclusão de seu curso de nível superior e os objetivos específicos; conhecer o perfil das ex-alunas do Prévestibular Comunitário São Luiz Rei de França; Identificar se houve mobilidade geracional das ex-alunas do Pré-Vestibular Comunitário São Luiz Rei de França em relação às suas mães; Compreender qual a percepção das ex-alunas do PréVestibular Comunitário São Luiz Rei de França, que também são oriundas das favelas do entorno de Costa Barros acerca do ingresso universitário e os impactos desse ingresso na vida dessas mulheres; Investigar como se deu a trajetória acadêmica das mulheres do Pré-Vestibular comunitário São Luiz Rei de França, moradoras de Costa Barros.

Interessante ressaltar que todas as entrevistadas frisaram a importância do ingresso no ensino superior em suas jornadas e que houve mudanças em suas trajetórias após a conclusão do ensino superior. Gostaríamos também de ressaltar que todas as entrevistadas avaliaram como positivo tanto o ingresso quanto a permanência na Universidade, e que essa inserção foi motivo de realização pessoal e também motivo de orgulho para suas famílias.

Enfim, é importante trazer, neste momento, que todas as entrevistadas avaliaram como positiva suas experiências no PVCSLRF, assim como o fato de ter esse tipo de curso no bairro, que conforme dito anteriormente, é um local de pobreza e que as pessoas vivem as múltiplas facetas da desigualdade social. Portanto, a experiência de ter um curso que não só capacita pessoas oriundas da classe trabalhadora para o ingresso na Universidade, mas também trabalha nelas questões de cidadania, cultura, etc. é de extrema relevância.

Por fim, gostaria de fazer uma colocação em relação às ex-alunas do CPVC, que tão generosamente cederam parte de seu tempo para contar um pouco de suas trajetórias pessoais e acadêmicas. Destaco também, quão verdadeira e singela foi cada entrevista, cada história contada e a beleza de cada depoimento. 
7.

\section{Referências bibliográficas}

AMARO, Sarita. Promoção de culturas e práticas afirmativas no ensino superior: ideias em ebulição. In: O Social em Questão - Ano XX - ํo 37Jan a Abr/2017.

ARRUZZA, Cinzia; BHATTACHARYA, Tithi; FRASER, Nancy. Feminismo para os 99\%: um manifesto. São Paulo: Boitempo, 2019.

ASSIS, Júlio Mendes. PRÉ-VESTIBULAR COMUNITÁRIO POMPEIA SANTO AGOSTINHO: História e Significados na Perspectiva dos Precursores. Dissertação (Mestrado em Serviço Social) - Pontifícia Universidade Católica do Rio de Janeiro, Departamento de Serviço Social: Rio de Janeiro, 2016.

BARBOSA, Maria Ligia de Oliveira. Destinos, Escolhas e a Democratização do Ensino Superior. In: Política \& Sociedade. Florianópolis. V. 14, n. 31, p. 256-282, set/dez. 2015.

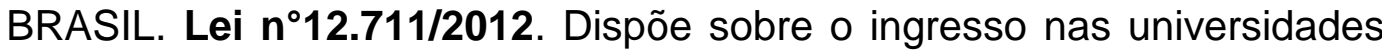
federais e nas instituições federais de ensino técnico de nível médio e dá outras providências.

Disponível em http://portal.mec.gov.br/cotas/docs/lei_12711_29_08_2012.pdf> Acesso em 09/05/2020.

. Ministério da Educação. O que Reuni? 2010. Disponível em <http://reuni.mec.gov.br/o-que-e-o-reuni>. Acesso em 16 de abril de 2021.

. Ministério da Educação. Programa Universidades Para Todos (ProUni) 2018. Disponível em <portal.mec.gov.br/ProUni> Acesso em 16 de abril de 2021.

Projeto de Lei $\mathbf{n}$ 1.277/2020. Inclui $\S 1^{\circ}-A$ ao art. 44 da Lei $n^{\circ}$ 9.394, de 20 de dezembro de 1996, para prever a prorrogação automática de prazos para provas, exames e demais atividade para acesso ao ensino superior em caso de reconhecimento de estado de calamidade pelo Congresso Nacional ou de comprometimento do regular funcionamento das instituições de ensino do país. Disponível em < https://www25.senado.leg.br/web/atividade/materias//materia/141354/pdf> Acesso em 16 de abril de 2021. 
Ministério da Saúde. Painel Coronavírus. Disponível em $<$ https://covid.saude.gov.br/> Acesso em 05 de Maio de 2021.

BRITO, Vanessa Silveira de.; GONÇALVES, Maria Alice Rezende. O PVNC na perspectiva dos egressos. In: O Social em Questão. Rio de Janeiro, Ano XX, n 37, 2017.

CAMPELO, Tereza; GENTILI, Pablo. As múltiplas faces da desigualdade. In: CAMPELO, T. (coord.) Faces da desigualdade no Brasil: um olhar sobre os que ficam para trás. Clacso, Flacso Brasil, Agenda lgualdade, p.10-15, 2017.

CAMPELLO, Tereza; GENTILI, Pablo; RODRIGUES, Monica; HOEWELL, Gabriel Rizzo. Faces da desigualdade no Brasil: um olhar sobre os que ficam para trás. Saúde debate [online]. 2018, vol.42, p.54-66.

CANDAU, Vera Maria Ferrão. Universidade e diversidade cultural: alguns desafios a partir da experiência da PUC-Rio. In: PAIVA, Angela (Org.). Ação afirmativa na universidade: reflexão sobre experiências concretas Brasil-Estados Unidos. Rio de Janeiro: Ed. PUC-Rio/Desiderata, 2004b. p. 87-108.

CORDEIRO, Ana Luisa Alves. Ações afirmativas na educação superior: mulheres negras cotistas e mobilidade social. In: Revista UNOCHAPECÓ - Ano -17 - n. 30 vol. 01 - jan./jun. 2013.

DUTRA, Natália Gomes dos Reis. SANTOS, Maria de Fátima de Souza. Assistência estudantil sob múltiplos olhares: a disputa de concepções. In: Ensaio: aval. pol. públ. Educ., Rio de Janeiro, v.25, n. 94, p. 148-181, jan./mar. 2017.

GOMES, Joaquim B. Barbosa. A RECEPÇÃO DO INSTITUTO DA AÇÃO AFIRMATIVA PELO DIREITO CONSTITUCIONAL BRASILEIRO. Revista de informação legislativa, Brasília a. 38 n. 151 jul./set. 2001.

HERINGER, Rosana; OLIVEIRA, Antônio José Barbosa de; SALVADOR, Andreia Clapp. Políticas de ação afirmativa: Direito e reconhecimento. In: O Social em Questão. Rio de Janeiro. Ano XVII - no 32 - 2014.

HERINGER, Rosana. Ação afirmativa e promoção da igualdade racial no Brasil: o desafio da prática. In: PAIVA, Angela (Org.). Ação afirmativa na universidade: reflexão sobre experiências concretas Brasil-Estados Unidos. Rio de Janeiro: Ed. PUC-Rio/Desiderata, 2004, p. 55 - 86.

. Rosana. Democratização da educação superior no Brasil: das metas de inclusão ao sucesso acadêmico. Revista Brasileira de Orientação Profissional, v. 19, n. 1, p. 7-17, 2018. Disponível em: http://dx.doi.org/1026707/1984-7270/2019v19n1p7. 
JARDIM, Tania Horsth Noronha. DESTINOS (IM) PROVÁVEIS: Um estudo sobre o perfil e a trajetória pessoal e profissional de alunos egressos de Serviço Social, beneficiários de Política de Ação Afirmativa da PUC-Rio. Tese (Doutorado em Serviço Social) Pontifícia Universidade Católica do Rio de Janeiro, Departamento de Serviço Social, Rio de Janeiro, 2015.

LARRUBIA, Bruno Costa. A ascensão social de jovens universitários afrodescendentes no Brasil e Estados Unidos. Tese (Doutorado em Ciências Sociais) Pontifícia Universidade Católica do Rio de Janeiro, Departamento de Ciências Sociais, Rio de Janeiro, 2016.

LEMOS, lara. Em reunião com senadores, Weintraub diz que Enem não foi feito para corrigir injustiças. Folha Uol. 05 de maio de 2020. Disponível em: https://www1.folha.uol.com.br/educacao/2020/05/emreuniao-com-senadores-weintraub-diz-que-enem-nao-foi-feito-paracorrigir-injusticas.shtml. Acesso em: 25 Mai. 2020.

LISTA DE BAIRROS DO RIO DE JANEIRO POR IDH. Wikipedia. Disponível em: https://pt.wikipedia.org/wiki/Lista_de_bairros_do_Rio_de_Janeiro_por_ID H. Acesso em 10/02/2020.

LISBOA, Tereza Kleba. Democracia de gênero: é possível um pacto entre as mulheres? In: O Social em Questão. Rio de Janeiro, Ano XX, $n^{\circ}$ 38, 2017.

MATTA, Gustavo Corrêa; et al. Os impactos sociais da Covid-19 no Brasil: populações vulnerabilizadas e respostas à pandemia. Rio de Janeiro: Editora Fiocruz, 2021.

MINAYO, C. Ciência, técnica e arte. 0 desafio da Pesquisa Social. In Minayo (org). Pesquisa social, teoria, método e criatividade. Vozes: Petrópolis, 2009.

NASCIMENTO, Alexandre do. Do Direito à Universidade à universalização dos Direitos: 0 movimento dos Cursos Prévestibulares Comunitários e as Políticas de Ação Afirmativa. Tese (Doutorado em Serviço Social) - UFRJ/ ESS / Programa de Pós graduação em Serviço Social, 2010.

PAIVA, Angela R. Cidadania, reconhecimento e ação afirmativa no ensino superior. Civitas: Porto Alegre, v. 15, n. 4 (127-154), out.-dez. 2015. 
PNUD. Desenvolvimento Humano e IDH. 2021. Disponível em https://www.br.undp.org/content/brazil/pt/home/idh0.html. Acesso em 16/04/2021.

SAFFIOTI, Heleieth. O poder do macho. São Paulo, Moderna, 1987.

SALVADOR, Andreia Clapp. Ação Afirmativa no Ensino Superior: Estudo da Política de Inserção de Alunos Pobres e Negros na PUCRio. Rio de Janeiro. Ed. PUC-RIO, 2008.

Andreia Clapp. Políticas de Reconhecimento X Políticas Redistribuição - Um Dilema Contemporâneo. In: O Social em Questão. Rio de Janeiro, Ano XIII, $n^{\circ} 23$, 2010.http://osocialemquestao.ser.pucrio.br/cgi/cgilua.exe/sys/start.htm?inf oid=155\&post\%5Fdata=user\%3Dnil\%26UserActiveTemplate\%3Dnil\%26si d\%3D23\&sid=23.

, Andreia Clapp. A Gênese da política de ação afirmativa da PUC-RIO. Uma parceria entre Universidade e Movimento Social. Rio de Janeiro. Ed. PUC-RIO, 2008.

Andreia Clapp. Política de Ação Afirmativa nas Universidades Brasileiras: o Papel Protagonista dos Movimentos Sociais. In: NEVES, A. V. (Org.). Democracia e participação social: Desafios contemporâneos. Campinas: Ed. Papel Social, 2016.

SILVA, Maria Ozanira da Silva e. Pobreza, desigualdade e políticas públicas: caracterizando e problematizando a realidade brasileira. Rev. Katál. Florianópolis v. 13 n. 2 p. 155-163 jul./dez. 2010.

VASCONCELOS, Natalia Batista. Programa Nacional de Assistência Estudantil: uma análise da evolução da assistência estudantil ao longo da história da educação superior no Brasil. Ensino Em-Revista, Uberlândia, v. 17, n. 2, p. 599-616, 2010.

WILLEMAN, Estela Martini. Condições de acesso e permanência das mulheres da periferia ao ensino superior: o caso de Duque de Caxias - RJ. Tese (Doutorado em Educação) Pontifícia Universidade Católica do Rio de Janeiro, Departamento de Serviço Social, Rio de Janeiro, 2013.

ZAGO, Nadir. Cursos pré-vestibulares populares: limites e perspectivas. In: PERSPECTIVA, Florianópolis, v. 26, n. 2, 149-174, jan./jun. 2008. 


\section{8.}

\section{Apêndices}

\section{1.}

\section{Roteiro de Entrevistas}

Entrevista com as Ex-Alunas do PVC:

Identificação (Perfil) do entrevistado:

Idade Atual:

Sexo:

Estado Civil:

Raça:

Em que ano entrou no Pré-Vestibular Comunitário São Luiz Rei de França:

Em que ano entrou na Universidade:

Que cursou concluiu:

Em que Universidade Estudou:

Nível de escolaridade atual:

Onde Morava antes do ingresso na Universidade e onde mora atualmente:

Bloco 1: Pré-vestibular Comunitário:

1- Você considera que o Pré-Vestibular Comunitário São Luiz Rei de França foi importante para sua inserção na universidade? De que forma ele foi importante?

2- Você considera que um Pré-Vestibular Comunitário, dentro de uma favela, foi importante para ingresso das mulheres das favelas de Costa Barros no ensino superior?

3- Foi sua primeira experiência enquanto aluna de um Pré-vestibular Comunitário?

4- Trabalhava enquanto participava das aulas do Pré-vestibular Comunitário?

Bloco 2: Políticas de Ação Afirmativas: 
5- Você acessou à Universidade através de Políticas de Ação Afirmativas? Qual?

6- Teve acesso à Assistência Estudantil? Quais?

7- O que você acha das Políticas de Ações Afirmativas?

8- Foi sua primeira graduação?

9- Outras pessoas de sua família já haviam tido acesso ao ensino superior?

10- Qual horário de seu curso? Teve alguma dificuldade em conciliar a faculdade com trabalho (caso tenha trabalhado no período da graduação)? Quais foram as dificuldades?

11- Com o que trabalhava antes da faculdade?

\section{Bloco 3: Trajetória pessoal, profissional e acadêmica:}

12- $\mathrm{Na}$ sua perspectiva, quais foram as maiores dificuldades com relação ao acesso à universidade e as maiores dificuldades na sua trajetória universitária?

13- Considera que teve mobilidade social após conclusão no ensino superior?

14- Considera que ser oriunda de ensino público (com diversas precariedades) dificultou seu acesso/ingresso na Universidade?

15- Qual a profissão de sua mãe e o Nível de escolaridade de sua mãe?

16-Trabalha na área da sua formação universitária?

17- Você vê mudança em sua trajetória após conclusão de seu curso?

18- Recebia ajuda financeira da família enquanto cursava a universidade?

19- Como foi sua trajetória acadêmica?

20- Qual o impacto de uma formação universitária em sua vida? 
8.2

Termo de Consentimento Livre e Esclarecido

$\mathrm{Eu}$,

Aceito livremente participar do estudo intitulado, Pré-Vestibular Comunitário São Luiz Rei de França e Sua Importância na Trajetória das Mulheres Moradoras de Favela - O Caso de Costa Barros, desenvolvido pela pesquisadora, Silvia Leticia Queiroz da Silva.

Mestranda: Silvia Leticia Queiroz da Silva.

Orientadora: Professora Doutora Andreia Clapp Salvador.

Contato do Departamento de Serviço Social da PUC - Rio: (21) 3527-1290.

(Assinatura do/a entrevistado/a)

de de 2020. 